\title{
THE HISTORICAL INFLUENCE OF RAILROADS ON URBAN DEVELOPMENT AND FUTURE ECONOMIC POTENTIAL IN SAN LUIS OBISPO
}

\author{
A Professional Report \\ presented to \\ the Faculty of California Polytechnic State University, \\ San Luis Obispo
}

\begin{abstract}
In Partial Fulfillment
of the Requirements for the Degree

Master of City and Regional Planning/Master of Science in Engineering (Transportation Planning Specialization)
\end{abstract}

by

Adrianna L. Jordan

August 2011 
(C) 2011

Adrianna L. Jordan

ALL RIGHTS RESERVED

Page ii 
Committee Membership

The Historical Influence of Railroads on Urban Development and Future Economic Potential in San Luis Obispo

Adrianna L. Jordan

August 2011

Hemalata Dandekar, Ph.D.

Advisor or Committee Chair

Cornelius Nuworsoo, Ph.D.

Committee Member

Claire Clark

Committee Member 


\section{Abstract}

The Historical Influence of Railroads on Urban Development and Future Economic Potential in San Luis Obispo

Adrianna L. Jordan

Today the sound of a train passing through San Luis Obispo may be intermittent and faint, but persistent nonetheless, a reminder that the railroad (displaced eventually by the automobile and accompanying expansion of highways and road systems, and later by air connectivity) was a significant force in the development of the City of San Luis Obispo. The sound of railroads evokes a sentimental reminder of the past, but the railroad’s continued presence in the city, cutting through its urban fabric, raises intriguing questions as to what constructive role it can play in the evolving city economy. Can the railroad make a contribution to the new economy of the $21^{\text {st }}$ Century? And if so, how? These questions are worth considering beyond nostalgia for a railroad-dominated past as we become more concerned, nationally and especially so in the State of California, about living sustainably. The aspiration to create communities that reduce dependence and expenditure on the automobile and the petroleum based economy that it represents has surfaced as an important goal, one that might enable us to live within our resource base. In this emerging context of heightened concern about integrating sustainability into current development, what role will, and might, the railroad play in shaping future developments and influencing land use? This work explores these questions by tracing the intertwined histories of transportation and land use in the City of San Luis Obispo from the $18^{\text {th }}$ century Spanish mission era to the $19^{\text {th }}$ century railroad era to the present-day automobile and air travel era.

Although the heyday of rail as an economic driver in the city has come and gone, San Luis Obispo’s Railroad District, with the award-winning Railroad District Plan for its place-making 
guide, is poised for continued revitalization. Public and commercial entities such as the Amtrak Station, the Railroad Museum, the Park Hotel building and its restaurants, and the Railroad Square Channel Commercial Building anchor the district and serve as pulse points of activity for locals and tourists alike. In addition, the Railroad District's excellent pedestrian and bicycle connectivity helps to link it with the rest of the city and channels people to it.

Given the present concern over greenhouse gas (GHG) emissions from motor vehicles, rising fuel costs, shortages of oil, and the centralized land-use patterns popular in New Urbanism and required by SB 375, it is possible that the railroad, or some other form of fixed rail public transportation might once again become a preferred mode of long-distance transport to the major metropolitan areas south and north of the city and beyond.

Keywords: railroads, city development, urban fabric, land use. 


\section{Acknowledgements}

I am enormously thankful for the patience, encouragement, guidance, and critical feedback of Dr. Hemalata Dandekar. Without her unwavering support throughout the last two years, I am not sure if I would have graduated at all.

In addition, I am extremely grateful to Claire Clark at the City of San Luis Obispo for her economic insight; Dr. Cornelius Nuworsoo for his advice, direction, and the opportunity to do research; Arnold Jonas of the San Luis Obispo Railroad Museum for his thoughtful comments and depth of historic railroad knowledge; Dr. Kelly Main for her support and friendship; and all of the anonymous individuals who agreed to be interviewed as stakeholders for this project. 
List of Figures $\quad$ X

1. The Regional Economy of San Luis Obispo Before and After the Railroad 1

1.1. Introduction 1

1.2. Pre-Railroads 2

1.3. Regional Connections 3

1.4. The Narrow Gauge Rail Connection to the Coast 5

1.5. Expansion of the Regional Economy by the Pacific Coast Railway 10

1.6. Financing and Routing the Southern Pacific Railroad 13

1.7. The Southern Pacific Connection to San Francisco and Los Angeles 16

2. The Demise of the Railroads

2.1. A Brief Timeline of Important Dates 23

2.2. Pre-World War I 23

2.3. World War I to World War II 27

2.4. The Post-War Period 30

3. City Fabric 33

3.1. Historic Shifts in the Street Grid 33

3.2. The City’s Residential Expansion 35

3.3. City Plats, Street Configurations, and the Southern Pacific 40

4. Historic Tourism, Economic Development, and the Railroad 44

4.1. The Southern Pacific and Tourism 44

4.2. Traders and Businesses $\quad 49$

5. Chinatown and the Chinese Contribution to the Railroad 56

6. Shifting Nature of the Relationship between the City and the Railroad 65 
6.1. Farmers and the Railroad $\quad 65$

6.2. City Form $\quad 67$

6.3. Notable Commercial Buildings Related to the Railroad 68

$\begin{array}{ll}\text { 6.4. Housing } & 72\end{array}$

7. Reflection on the Railroads $\quad 87$

7.1. Transportation Eras in San Luis Obispo $\quad 87$

7.2. The Influence of the Airport on Land Use and Development 90

7.3. The Union Pacific’s Continued Influence on Land Use in the City 92

7.4. The Rise of the Southern Pacific as a Freight Railroad 92

7.5. The Future of Passenger Rail in the City of San Luis Obispo 93

7.6. Sustainability and the Railroad 95

8. A Conceptual Plan for the Future Role of Railroads in the City of San Luis Obispo 99

8.1. Tourism in Today’s City of San Luis Obispo 99

8.2. The Railroad District Revitalization Plan 102

8.3. Potential for Economic Growth 103

8.4. Future Economic and Tourism Growth 107

$\begin{array}{ll}\text { 8.5. Connectivity } & 110\end{array}$

8.6. Case Studies 112

8.7. The Railroad History Tour 115

$\begin{array}{ll}\text { 9. Conclusion } & 117\end{array}$

10. References $\quad 119$ 
Table 8.1. Railroad District Case Studies

113

Page ix 


\section{List of Figures}

Figure 1.1: Map of the Town of San Luis Obispo: "Blocks, Subdivisions and Present Ownerships 1872"

Figure 1.2: Cave Landing aka “Mallagh’s Wharf” 4

Figure 1.3: 30-inch gauge Horse Rail Road and 36-inch Narrow Gauge Railroad at Avila 6

$\begin{array}{ll}\text { Figure 1.4: PCRR track remnants at present-day Port San Luis } & 7\end{array}$

Figure 1.5: Pacific Coast Railway Terminal in San Luis Obispo 8

Figure 1.6: Port Harford with the Hotel Marre $\quad 9$

$\begin{array}{ll}\text { Figure 1.7: Extent of the Pacific Coast Railway as of } 1915 & 10\end{array}$

$\begin{array}{ll}\text { Figure 1.8: Stenner Creek Railroad Trestle } & 17\end{array}$

Figure 1.9: 1926 Sanborn Map with Roundhouse at Upper Right Corner 18

Figure 1.10: Historic Aerial Showing Roundhouse and Southern Pacific Railyards in $\begin{array}{ll}\text { Lower Right Corner } & 18\end{array}$

Figure 1.11: Southern Pacific 1895 Freight Warehouse 20

$\begin{array}{ll}\text { Figure 1.12: Southern Pacific Turntable } & 20\end{array}$

Figure 2.1: San Luis Obispo Railroad District Public Art Listing Important Dates 22

$\begin{array}{ll}\text { Figure 2.2: San Luis Lighthouse Station } & 24\end{array}$

Figure 2.3: The Present-Day Layout of the Union Pacific Railyard 26

Figure 2.4: The Southern Pacific Transportation Company Building 27

Figure 2.5: American World War II Propaganda Encouraging Citizens Not to Drive Alone $\quad 29$

Figure 3.1: Shift in the city's grid at High Street 33

Figure 3.2: Street shadow patterns in a Jeffersonian Grid (left) and a Spanish Grid (right) 34

Figure 3.3: 1874-1891 Land Annexations Around the Proposed Right of Way of the Southern Pacific Railroad

Figure 3.4: 1887 - Deleissigues Addition (block 5). Labeled Nos. 2/5/11 on left map. 
Figure 3.5: 1887 - Loomis Tract. Labeled No. 4 on upper map.

Figure 3.6: 1887 - McBride Tract. Labeled No. 6 on left map.

Figure 3.7: 1887 - Buena Vista Addition. Labeled Nos. 3/9 on left map.

Figure 3.8: Original Johnson Avenue Railroad Bridge Undercrossing shown just before It was replaced with a wider undercrossing in 1958

Figures 3.9 and 3.10: The Loomis Tract (1887) and the Loomis and Osgood Resubdivision (1894)

Figure 4.1: The Ramona Hotel with convenient horsecar to the railway station

Figure 4.2: The interior of a suite at the Ramona Hotel

Figure 4.3: Current photograph of the Ramona Hotel Depot on the Dallidet Adobe Grounds

Figure 4.4: Ramona Hotel Depot in original location adjacent to the Southern Pacific Tracks

Figure 4.5: The original Andrews Hotel

Figure 4.6: An 1887 advertisement about local economic resources

Figure 4.7: The back of the Channel Commercial building as it looks today

Figure 5.1: Iron Road Pioneers (2003)

Figure 5.2: Mee Heng Low Chop Suey Shop

Figure 5.3: Chong’s Hand Made Candies

Figure 5.4: Looking east down Palm Street in turn of the century Chinatown

Figure 5.5: Looking west down Palm Street in turn of the century Chinatown

Figure 5.6: The Ah Louis Store as it looks today

Figure 6.1: Farmers Alliance Building in Paso Robles

Figure 6.2: Cast-iron Sinsheimer Bros. storefront

Figure 6.3: The Call/Parkview Hotel at 1703 Santa Barbara Street 
Figure 6.4: The Del Monte Grocery at 1901 Santa Barbara Street

Figure 6.5: Hotel Park / The Glen Dell Hotel $\quad 71$

Figure 6.6: Location of railroad worker housing in 1904

Figure 6.7: Location of railroad worker housing in 1914

Figure 6.8: Two examples of "Imperial Addition” homes that typically housed railroad workers and their families

Figure 6.9: Three homes identified as potential contributors to the possible expansion of the Railroad District east of the railroad.

Figure 6.10: Notable homes related to the railroads

Figure 6.11: Typical railroad worker housing in San Luis Obispo

Figure 6.12: Martha Dunlap House at 1511 Morro Street

Figure 6.13: Stanton/Lewin House at 752 Buchon Street

Figure 6.14: Troutsdale House at 779 Buchon Street

Figure 6.15: Erickson House at 687 Islay Street

Figure 6.16: Manderscheid House at 963 Broad Street

Figure 6.17: Willett House at 670 Islay Street

Figure 6.18: Galewski House at 1725 Santa Barbara Street

Figure 6.19: 1117 Marsh Street

Figure 6.20: 1129 Marsh Street

Figure 6.21: 1135 Marsh Street

Figure 6.22: 1141 Marsh Street

Figure 6.23: Good example of a “shotgun” house at 2276 Lawton Street

Figure 7.1: Map of the San Luis Obispo Street Railway

Figure 7.2: Aviation safety map of the southern portion of the City of San Luis Obispo 
Figure 7.3: Amtrak Coast Starlight Locomotive and Superliner Cars in San Luis Obispo

Figure 8.1: The Jennifer Street Bridge in the Railroad District

100

Figure 8.2: The Historic Freighthouse Building that will House the Railroad Museum

100

Figure 8.3: The San Luis Obispo County Historical Museum

Figure 8.4: New public art at Port San Luis highlighting the Pacific Coast Railway

Figure 8.5: An Example of the Railroad Vernacular Architectural Style in the Railroad District

Figure 8.6: Opportunities and Constraints Map

Figure 8.7: The upscale Sanitarium Bed \& Breakfast

Figure 8.8: The Site of the Demolished Southern Pacific Steam Locomotive

Figure 8.9: Old Sears Warehouse in the Railroad District

Figure 8.10: Existing Short-Term Bicycle Parking in the Railroad District

Figures 8.11 and 8.12: Two examples of "kiddie trains” 


\section{Chapter 1: The Regional Economy of San Luis Obispo Before and After the Railroad}

\subsection{Introduction}

The aspiration to create communities that reduce dependence and expenditure on the automobile and the petroleum based economy that it represents has surfaced as an important goal, one that might enable us to live within our resource base. In this emerging context of heightened concern about integrating sustainability into current development, what role will, and might, the railroad play in shaping future developments and influencing land use? Can the railroad make a contribution to the new economy of the 21st Century? And if so how? This work traces the intertwined histories of transportation and land use in the City of San Luis Obispo from the 18th century Spanish mission era to the 19th century railroad era to the present-day automobile and air travel era. The study also identifies potential for the railroad legacy to continue to contribute to the economy of San Luis Obispo.

Prior to the railroads, San Luis Obispo was a small mission town surrounded by cattle ranches with few prospects for attracting business investment. One of the major obstacles was the town's physical isolation - with the Santa Lucia mountain range effectively cutting it off from reliable overland communication with San Francisco, the town originally turned toward the ocean as the primary means of interregional transportation and connectivity to a larger economy and commerce. The development of a rail link served to break this isolation. This chapter establishes the link between the railroads and the growth of the regional economy of San Luis Obispo. 


\subsection{Pre-Railroads}

San Luis Obispo emerged as a small town centered on a mission established in 1772 by the Franciscan Fathers. An1872 map of the City of San Luis Obispo (Figure 1.1) reveals that the Catholic Mission Church’s orchards and lands around Broad, Chorro, and Monterey streets are a dominant part of the town, and encircled by individual land holdings. Set in the rich farming lands of what is now referred to as the Central Coast region, the City of San Luis Obispo was a regional hub of activity adding value to production in the immediate hinterland. However, due to challenging geography, it remained isolated from the rest of the state until advances in transportation technology rendered it a staging ground for people and freight movement between Los Angeles and San Francisco. The Santa Lucia Mountains and the steep Cuesta Grade to the north of the town and the rugged Irish Hills to the south of the town made it extremely difficult to reach the City of San Luis Obispo via an overland route for close to 100 years. Therefore, the Pacific Coast Railway linking the town to the coast and to the south, and later, the Southern Pacific Railroad connecting to San Francisco and Los Angeles, served as transportation catalysts, significantly reshaping the morphology of the city. 


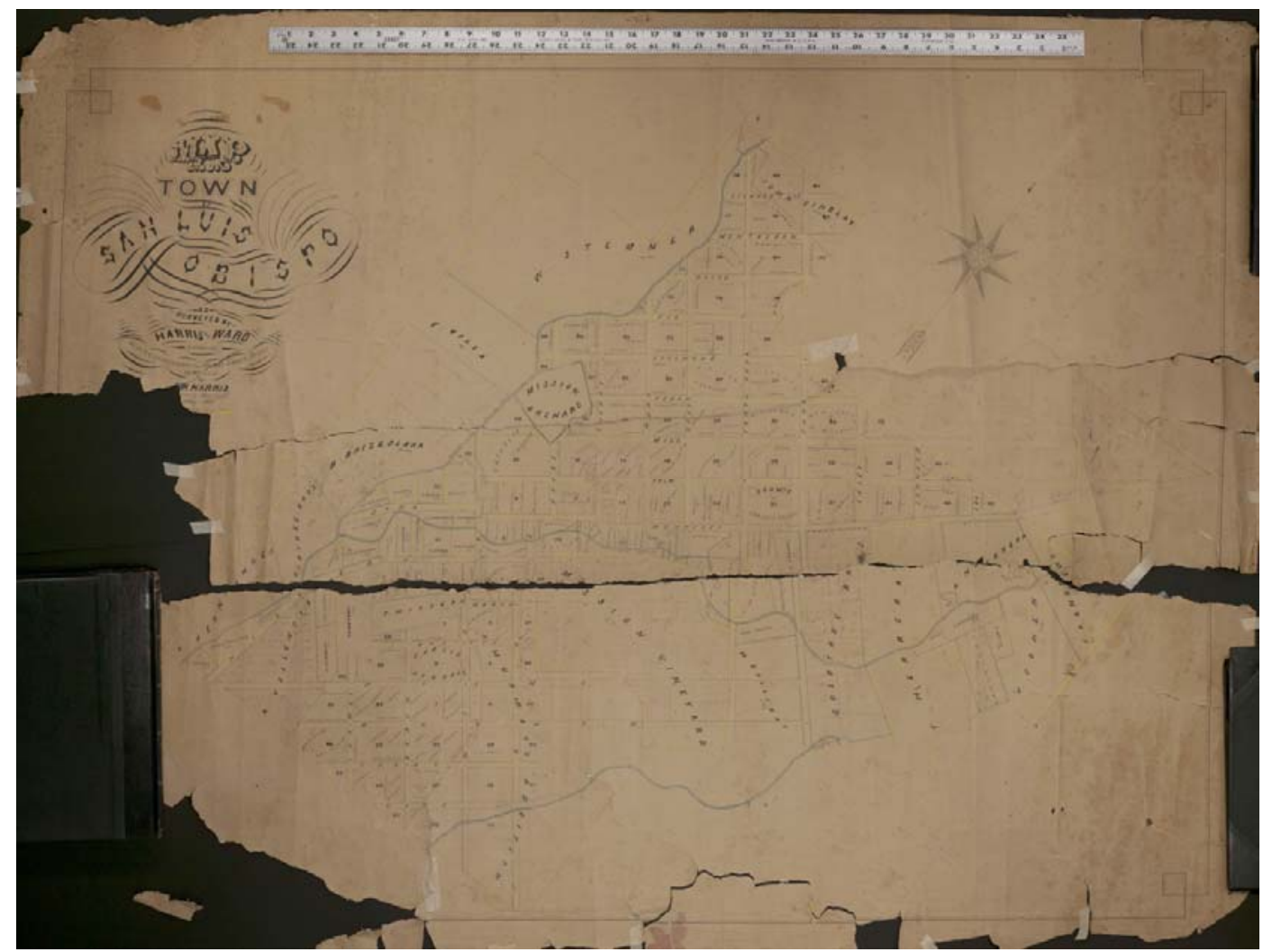

Figure 1.1: Map of the Town of San Luis Obispo: "Blocks, Subdivisions and Present Ownerships 1872”

Courtesy of the History Center of San Luis Obispo County.

\subsection{Regional Connections}

The main way to transport people and goods to the Central Coast region was by horseback, stagecoach, or wagon. Roads heading north to San Francisco were of relatively poor quality until the development of Old Stagecoach Road in 1876. Served by six relay stations between the City of San Luis Obispo and Soledad (Atascadero News, 1916), the road was built with Chinese labor and cost approximately $\$ 20,000$. It remained in service until the modern route for Highway 101 was laid out in 1915 (Miossi, n.d.). 
Competing with the overland routes, Cave Landing was founded in 1855 by Barkley Clements and Charles T. Rommie at Avila Beach approximately one mile south of the present town of Avila (Figure 1.2) with a small wharf, warehouse, and derrick (Five Cities Times-PressRecorder, 1989). This facilitated an increase in transportation via steamships, which plied up and down the coast from Seattle to San Diego. At the time, the main economic base for the San Luis Obispo area was cattle and cattle products such as hides were typically shipped out of the county via wharfs such as Cave Landing.

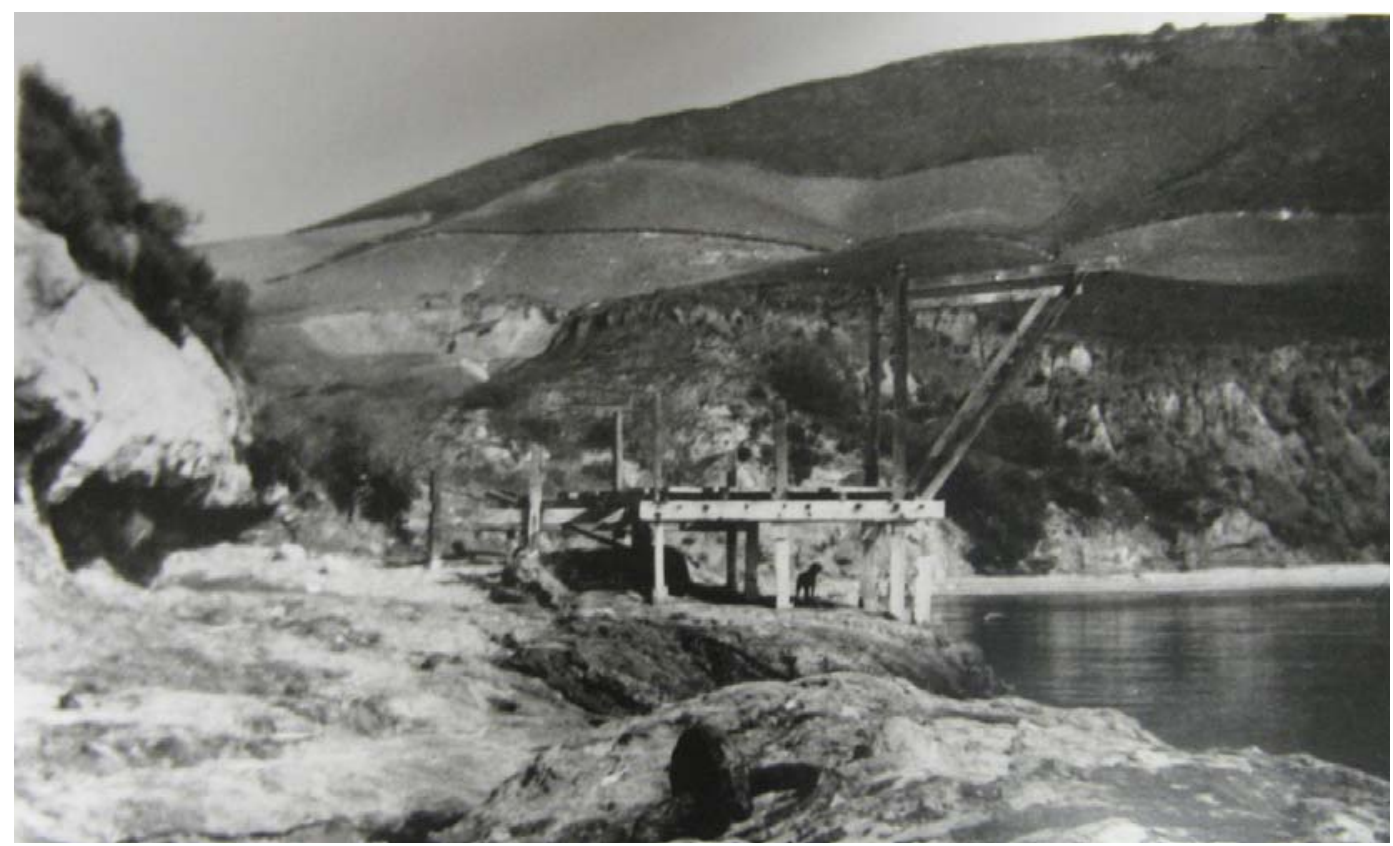

Figure 1.2: Cave Landing aka "Mallagh's Wharf" Photo Courtesy of the San Luis Obispo County History Center

A local cattle ranch called the Huer Huero ranch was occupied starting around 1839 by José Mariano Bonilla who served as a scribe to Governor Figueroa. Shortly thereafter, the ranch was raided twice by the Tulare Indians, and in one of the raids Bonilla’s brother was killed.

Discouraged by events, Bonilla sold the land to Francis Branch in 1847 in exchange for 253 cattle. By 1856 the ranch was owned by Captain David P. Mallagh (Nicholson, 1980). Disastrous droughts between 1862 and1864 caused the majority of old ranchero farms to go bankrupt, and 
most of the ranchers were bought out by dairymen. Towards the end of the drought period, in 1864 Cave Landing was purchased, improved, and commercialized by Mallagh. At this time, the majority of goods arriving at Cave Landing originated in San Francisco and included building materials such as redwood and iron, coal, linens, and general household merchandise. Local exports reflected the ranching and agricultural focus of the community and commonly included asphalt and bitumen, ore, hides, tallow, grains, beans, sheep, cattle, hogs, and most notably, dairy products (Nicholson, 1980).

In 1865, Edgar Willis Steele and his brothers, dairy farmers who owned the Pescadero Ranch in San Mateo County, purchased 45,000 acres in the Edna Valley for \$1.10 per acre and introduced the modern dairy industry to San Luis Obispo County. In 1866, Edgar Steele bought portions of Corral de Piedra, El Pismo, Bolsa de Chamisal, and Arroyo Grande ranchos. The Steele family specialized in cheese and operated five dairy farms, each with 150 head of dairy cattle. By 1870 San Francisco's Commercial Herald, the standard commercial and credit reporter for the West, valued the Steele’s holdings at $\$ 150$ million.

\subsection{The Narrow Gauge Rail Connection to the Coast}

In 1869 John Harford founded the People’s Wharf at Avila to compete with Cave Landing. Unfortunately, the downfall of both Cave Landing and the People's Wharf was their exposed location in water that was too shallow to seriously cater to the needs of the steamers that were plying the Pacific coast. However, by 1873, after seeking a more sheltered location, Harford purchased one and one-quarter miles of waterfront property from the Avila family and built a new wharf named Port Harford in the lee, wind-protected side of Point San Luis. This area, from 
the mouth of San Luis Creek to the site of the present-day Port San Luis Pier, was graded for a railroad right-of-way (Parsons, 1995).The wharf reached 540 feet out from the rocky shore to water averaging fifteen feet deep. Using light 15-pound steel rail, he built a 30-inch gauge railroad connecting the wharf to the mouth of the San Luis Creek, making it one of the first narrow gauge railroads in the state (Best, 1964) (Figure 1.3). In 1874 San Francisco Financier Charles Goodall purchased all of Harford's facilities for \$30,000 and founded the San Luis Obispo and Santa Maria Valley Railroad. That same year, Avila was subdivided and established as a town.

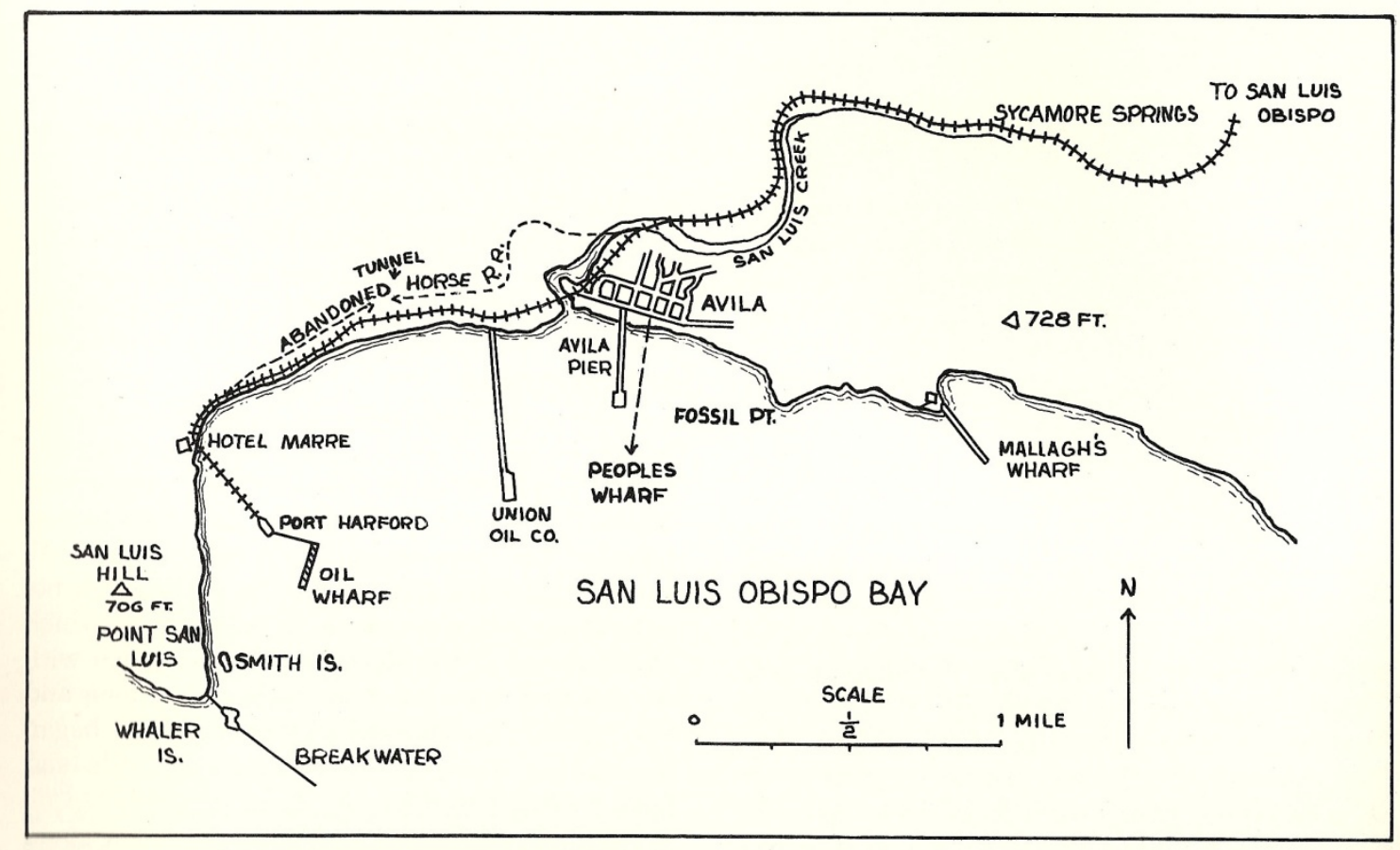

Figure 1.3: 30-inch gauge Horse Rail Road and 36-inch Narrow Gauge Railroad at Avila Map Courtesy of Best (1964).

Up until 1876 the railroad was horse-powered. Flat cars were loaded with goods from the steamships and "then driven up an incline to a tunnel at which point the horses were unhitched and the railroad cars rolled down the easterly incline to the town of Avila and Harford's warehouse” (Parsons, 1995). After three years of using this labor-intensive horsepower to move 
goods along fixed rails, in 1876 a competing company, to be later renamed the Pacific Coast S.S. Co., bought the railroad, re-graded and re-located the railway alignment closer to the water to avoid the tunnel, and constructed a 36-inch narrow-gauge track. Interestingly, the steam locomotive itself was only 30" wide. Typically, narrow gauge rail was built where terrain was mountainous and made wider-gauge railroads more difficult and/or economically challenging; however, although effectively traversing the rugged terrain of the Irish Hills was certainly a factor (Best, 1964), it was not the main reason that the narrow gauge rail was selected. Instead, company founders preferred narrow gauge for cost-effectiveness. Less right-of-way meant lower construction costs, and smaller less costly locomotives (Rice, 2006).

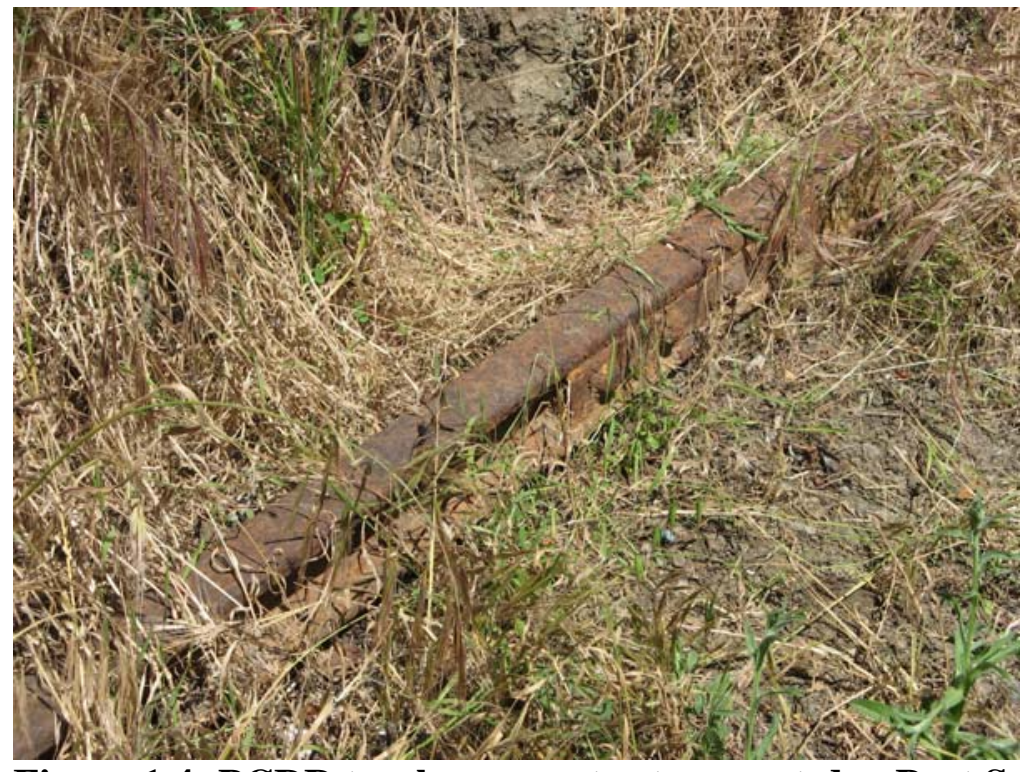

Figure 1.4: PCRR track remnants at present-day Port San Luis Photo: Adrianna Jordan.

The Pacific Coast Company extended the railroad tracks from Port Harford to a new railcomplex in the City of San Luis Obispo along a route that roughly aligns with the present-day Bob Jones Trail. Recently, present-day Port San Luis excavated a section of the filled-in narrowgauge tracks in the area between historic Port Harford and Avila (Figure 1.4). Continuing on from the community of Avila, the tracks terminated at the intersection of Higuera and South 
Streets in San Luis Obispo at a rail complex consisting of a passenger terminal, a locomotive turn table, rail freight yards, and lumber yards (Figure 1.5). The rail yard, related warehouses, and lumber yards were located east of Higuera Street between High Street and Beebee Street, and the passenger depot was on the southeast corner of Higuera and South.

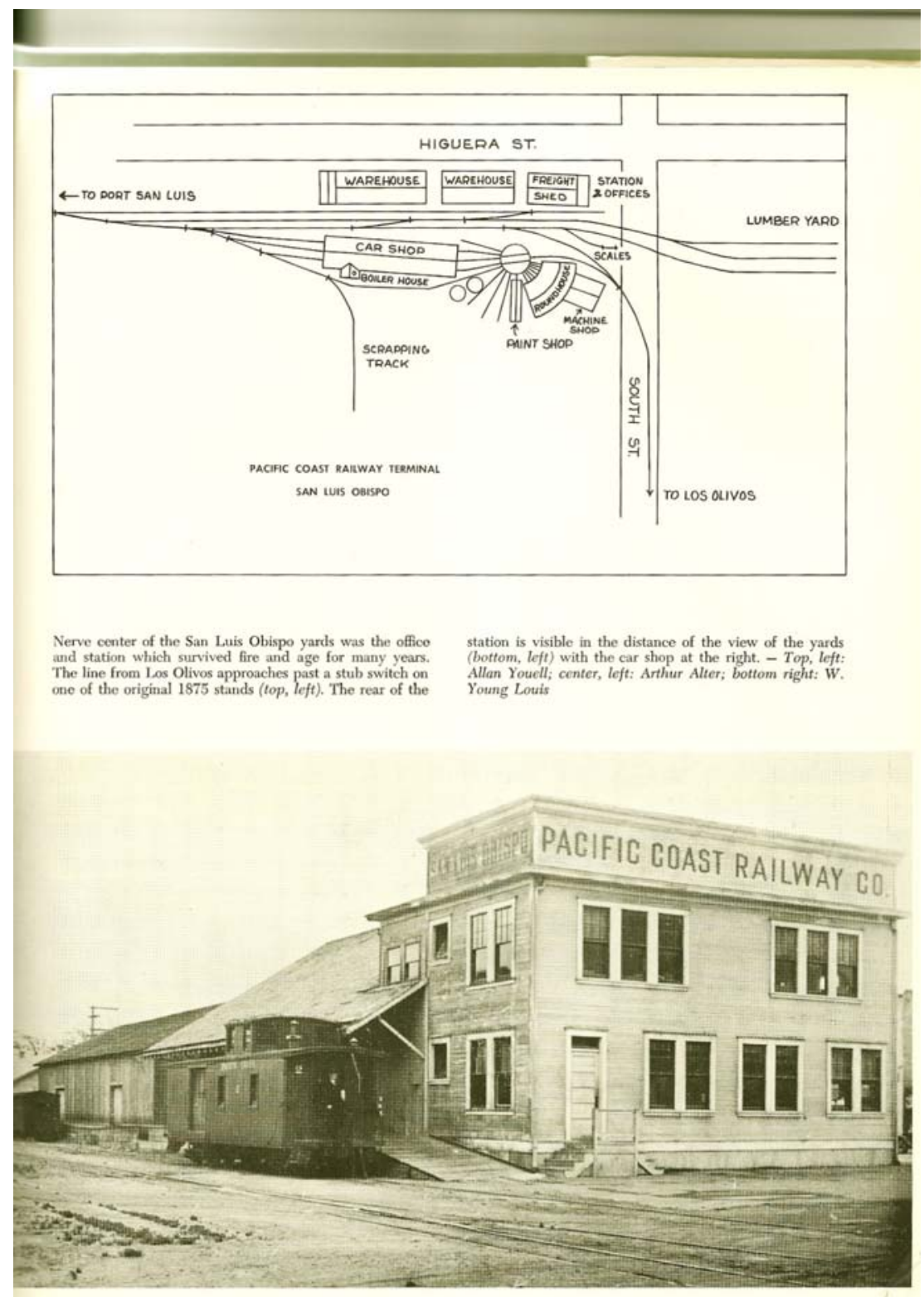

Figure 1.5: Pacific Coast Railway Terminal in San Luis Obispo Figure Courtesy of Best (1964). 
The December 1999 Public Hearing Draft of the Mid-Higuera Street Enhancement Plan explains that one of the original buildings in the rail complex was a long warehouse erected in 1876 for Schwartz, Harford \& Company for the purpose of loading "beans and other commodities on the rail cars for shipment to the Port. This warehouse was later owned by Loomis and Sons, and was commonly referred to as the 'Loomis Building'." This site is now occupied by the Pacific Coast Center office and shopping complex and is listed on the National Register of Historic Places as the "Pacific Coast Company Grain Warehouse”. According to former City of San Luis Obispo Senior Planner and railroad enthusiast Jeff Hook, the foundation of this complex is constructed of brick from the original Pacific Coast Railway passenger terminal, and although most of the original metal and framing is gone, the form and contours of that terminal are reflected in the center’s “railroad vernacular” architecture.

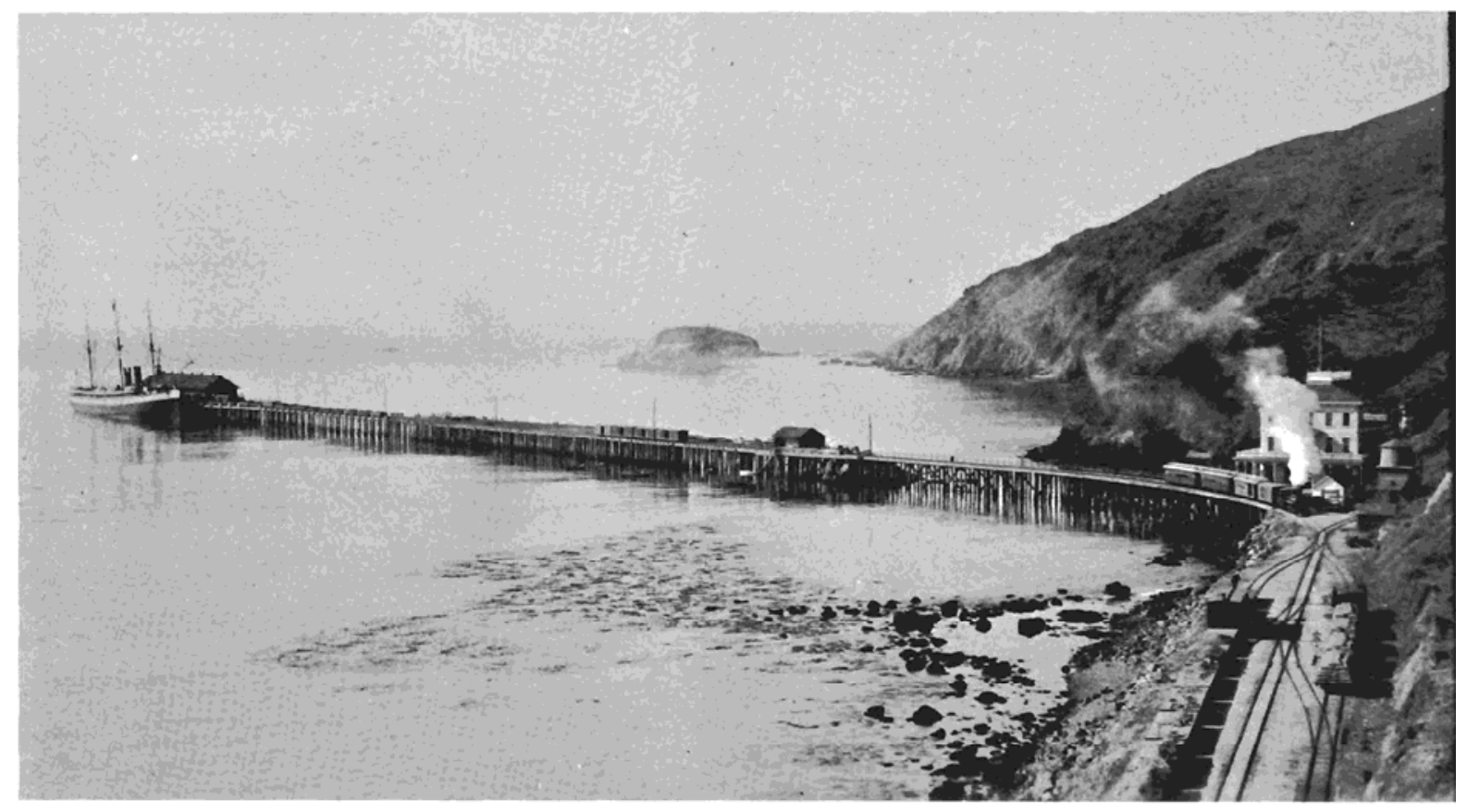

Figure 1.6: Port Harford with the Hotel Marre Photo Courtesy of Best (1964). 
The establishment of the first narrow-gauge railroad in 1876 between Port Harford (present-day Port San Luis) (Figure 1.6) and the City of San Luis Obispo opened up the land-locked economy of this region to trans-shipment of regional products by sea, north to San Francisco. This narrow gauge rail, however, was fated to become obsolete.

\subsection{Expansion of the Regional Economy by the Pacific Coast Railway}

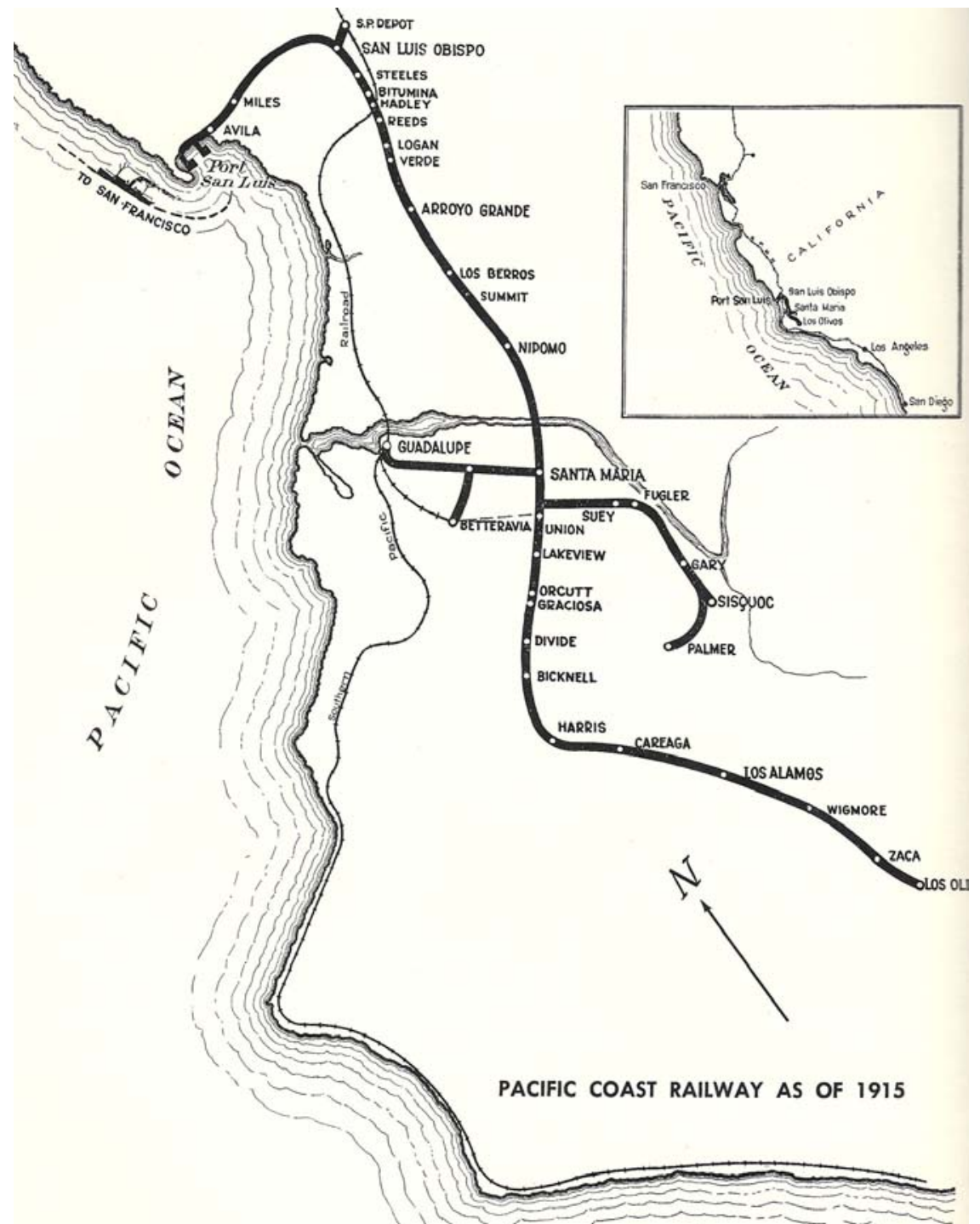

Figure 1.7: Extent of the Pacific Coast Railway as of 1915 Map Courtesy of Westcott and Johnson (1998). 
In 1878 a storm destroyed the People’s Wharf at Avila and the Point Sal Landing near Guadalupe, which gave the more sheltered Port Harford a short-lived local shipping monopoly. Then, in 1882, the railway operator of the narrow-gauge rail from the port to the interior cities merged with the Pacific Steamship Company and was re-christened the Pacific Coast Railway. Gradually, the railroad was extended from Port Harford to Arroyo Grande, Nipomo, Santa Maria, Los Alamos, and finally to Los Olivos increasing the length of the Pacific Coastal Railway line to 76 miles (Figure 1.7). By the late 1880’s, Port Harford was handling over 400 ships per year. This coincided with the beginning of oil exploration in the Santa Maria Valley in 1888 leading to large-scale oil discovery and extraction operations in the Orcutt Oil Field located in the Solomon Hills south of the City of Santa Maria around the dawn of the $20^{\text {th }}$ century (County of Santa Barbara, 2005). By 1904, there were 22 oil wells in production. The burgeoning local oil industry necessitated the ordering of special tank cars to allow local petroleum products to be shipped to Port Harford on the narrow-gauge Pacific Coast Railway for trans-shipment via oil tankers to ports throughout the world (Parsons, 1995).

Concurrent to the discovery of oil in the Santa Maria Valley, the cultivation of sugar beets as a commodity crop also gained traction in the region. Located between Santa Maria and Guadalupe, the company town of Betteravia was founded in 1898 with the sole purpose of processing sugar beets. Then, in 1906 the Pacific Coast Railway opened an electrified line to haul sugar beets that...

...ran westward from Santa Maria to a ranch, about 4 [sic] miles from the depot... The PC [sic] completed the additional 4 [sic] miles to extend the branch to Guadalupe early in 1909. Best (1864) gives the date of the first passenger run from Santa Maria to 
Guadalupe as April 17, 1909. By 1909, the PC [sic] had built another electric locomotive, E-2 to handle freight. This 0-4-4-0 headed the first train into Guadalupe, pulling three coaches loaded with passengers. A week later, E-1 and combination coach \#300 took over this interurban service, while E-2 returned to hauling sugar beets” (Westcott and Johnson, 1998).

Although its primary cargo was sugar beets, it also hauled passengers in box cars with wooden benches. This was California's smallest electric passenger operation, "boasting on its roster but a single steel center entrance electric passenger car purchased in 1912” (Rice, 2006).

According to Best (1964), another new branch opened in June 1909. The electric was extended south from a point about halfway between Santa Maria and Guadalupe to the Union sugar factory at Betteravia. Previously, cars of sugar beets from this area had gone into Santa Maria, then south to Union, where they were switched off to the sugar factory. This new electrified branch shortened the haul for beets, and the branch from the mainline to Betteravia built in 1898 was soon abandoned (Westcott and Johnson, 1998).

The first efforts to link San Luis Obispo to other regions for trade purposes started off with local entrepreneurial investors financing and constructing the basic infrastructure such as a port, a stagecoach road, or a rail right-of-way. Once the basic infrastructure was in place, outsiders from San Francisco with access to large amounts of capital showed up in town to strike deals. For instance, following John Harford's grading of the rail right-of-way for Port Harford in the early 1870s, San Francisco businessmen quickly took notice:

Harford's success attracted the attention of investors up and down the Pacific Coast. Despite a statewide depression, which had arrested the supply of investment capital in 
San Francisco, businessmen were on the lookout for "good buys" in Central and Southern California. William W. Chapman, William W. Stowe, and Henry B. Tichenor formed a syndicate called the San Luis Obispo Railroad on January 30, 1873...The group proposed to build a steam rail line running from the terminus of Captain Harford's horse-drawn line at the mouth of San Luis Creek and the town of San Luis Obispo (Krieger, 1989). Although a lack of readily available capital delayed the project for a year, construction of the railway was authorized on March 2, 1874. Soon after, Harford sold his wharf and horse-drawn railway to Goodall and his partners for $\$ 30,000$. In August of 1876 the railway started to make runs between the City of San Luis Obispo and Avila and became profitable the same year.

\section{$\underline{1.6}$ Financing and Routing the Southern Pacific Railroad}

In contrast to the Pacific Coast Railway, most of the financing of the Southern Pacific from its inception was provided by wealthy San Francisco businessmen. Seeing an opportunity to expand San Luis Obispo's ability to trade with other regions, local businessmen took notice of the overland rail line and did their best to attract the railroad to their city by forming a Board of Trade to lobby the Southern Pacific. "By the end of 1887, the finance committee of the Board of Trade announced that contributions amounted to $\$ 3,296$, and they had spent $\$ 2,684$, all for the promotion of the county” (Nicholson, 1980). Despite the Board's efforts, very little news of the Southern Pacific's extension trickled through town in 1887. The only pieces of information came from reporters who had interviewed Southern Pacific executives. According to the interviews, the executives were trying to complete the rail "as soon as possible". Additional hope arrived in the form of right-of-way property sales between local ranchers and the Southern Pacific. 
In a June 1888 interview, Charles Crocker was quoted as saying that the Southern Pacific would “assume operations [between Templeton and Santa Barbara] sometime this fall or winter” and added that he expected the Cuesta Grade tunnels to be the first priority. (Nicholson, 1980). Several months later, R.E. Jack, Isaac Goldtree, and J.P. Andrews were contacted by the Southern Pacific to obtain land for a depot and machine shops in addition to a rail right-of-way through the City of San Luis Obispo.

Although most of the large land owners in town were eager to provide right-of-way for the rail and viewed it as a way to increase their land value, smaller land owners felt more ambivalent about the prospect, or even openly opposed it since it often times meant physically cutting their land in half and destroying existing residential and commercial structures. Nonetheless, in 1889 a total of 55 contracts for lot sales had been acquired. Despite this, some of the more prominent citizens in the community, among them J.P. Andrews, remained noncommittal about routing the Southern Pacific through town; or they held on to their properties hoping that the railroad would eventually break down and buy the land for as much as four times what is was worth, and therefore appeared to put their own interests in front of the good of the community. In Andrews' case, he was holding out because he preferred the railroad to be routed along Stenner Creek. Edwin Goodall, president of the company who owned the Ramona Hotel, summed up the reluctance of a few of the property owners when he stated:

“There is an old and generally accepted maxim that self protection is the first law of nature. I think it is unreasonable for one property holder to expect another to voluntarily make sacrifices; in other words to ruin his own property for the benefit of his neighbor or 
the public... I am not sufficiently patriotic or philanthropic to ruin my property for the benefit of others” (Nicholson, 1980).

Due primarily to the highly influential and vocal minority who opposed the railway on the east side of San Luis Obispo, a delegation was sent to San Francisco to meet with the Southern Pacific in hopes that they would convince them to route the railway along the western edge of town instead.

Following months of silence after the requested route change, R.E. Jack traveled to San Francisco and eventually succeeded in securing a meeting with Crocker. Crocker reminded him that the Southern Pacific was investing 1.5 million dollars in the rail line and that the citizens of the City of San Luis Obispo were only offering \$30,000 in rail right-of-way in return. In addition, Crocker refused to budge on the issue of the rail right-of-way arguing that the eastern route was the most feasible route. The squabbling over the route location among the businessmen of the City of San Luis Obispo had added to the delay in getting the Southern Pacific to town. It was not until October of 1890 when a contract was finally signed between representatives of the railroad and representatives of the town to complete the rail route into San Luis Obispo. In December 1890, it became apparent that San Luis Obispo needed \$20,000 “more than it could raise locally in order to complete purchase of railroad right-of-way land” (Nicholson, 1980). Negotiations were entered into with the San Jose Board of Trade to provide the additional necessary financing. For San Jose, \$20,000 was a drop in the bucket for eventually getting in return a direct through-route to the City of San Luis Obispo and ultimately, Los Angeles. 
By February 1891 almost all the require right-of-way was secured; then, in December of 1891, a call for bids on the construction of the Cuesta Grade tunnels was published in the San Francisco papers. By 1892, construction on the line had again started up in San Luis Obispo County.

\subsection{The Southern Pacific Connection to San Francisco and Los $\underline{\text { Angeles }}$}

Although the City of San Luis Obispo prospered as a regional economic hub by virtue of the Pacific Coast Railway, it was still relatively isolated from the rest of the state. It lacked a rail connection to San Francisco in the north and Los Angeles in the south. The Southern Pacific Railroad terminated at Santa Margarita north of the City of San Luis Obispo for years, as it was both costly and dangerous to construct the tracks across the Cuesta Grade. Finally, on May $5^{\text {th }}$, 1894, following extensive lobbying by local prominent businessmen such as Isaac Goldtree and J.P. Andrews, and after deals to secure local financial backing were struck, the City of San Luis Obispo was connected to San Francisco via rail. Getting the train over the Cuesta Grade was an enormous feat of $19^{\text {th }}$ century engineering. Both the backside of the grade and the Stenner Creek crossing had been challenging design problems. Indeed:

The Stenner Creek railroad trestle (Figure 1.8) is the most impressive relic of that day in early May, 1894, when the Southern Pacific mainline from the north finally linked San Luis Obispo to the wider world. The trestle was the last step in the monumental effort to tunnel and switchback a route through the Santa Lucia Mountains. The 935 foot long, 90 foot tall steel superstructure was partially preassembled in Pittsburgh, then erected and bolted to its granite piers on site. A century later Amtrak trains and heavy freights still 
cross its seemingly skinny girders every day (retrieved from

http://www.heritageshared.org/docs/livinglandtour3.html, 2011).

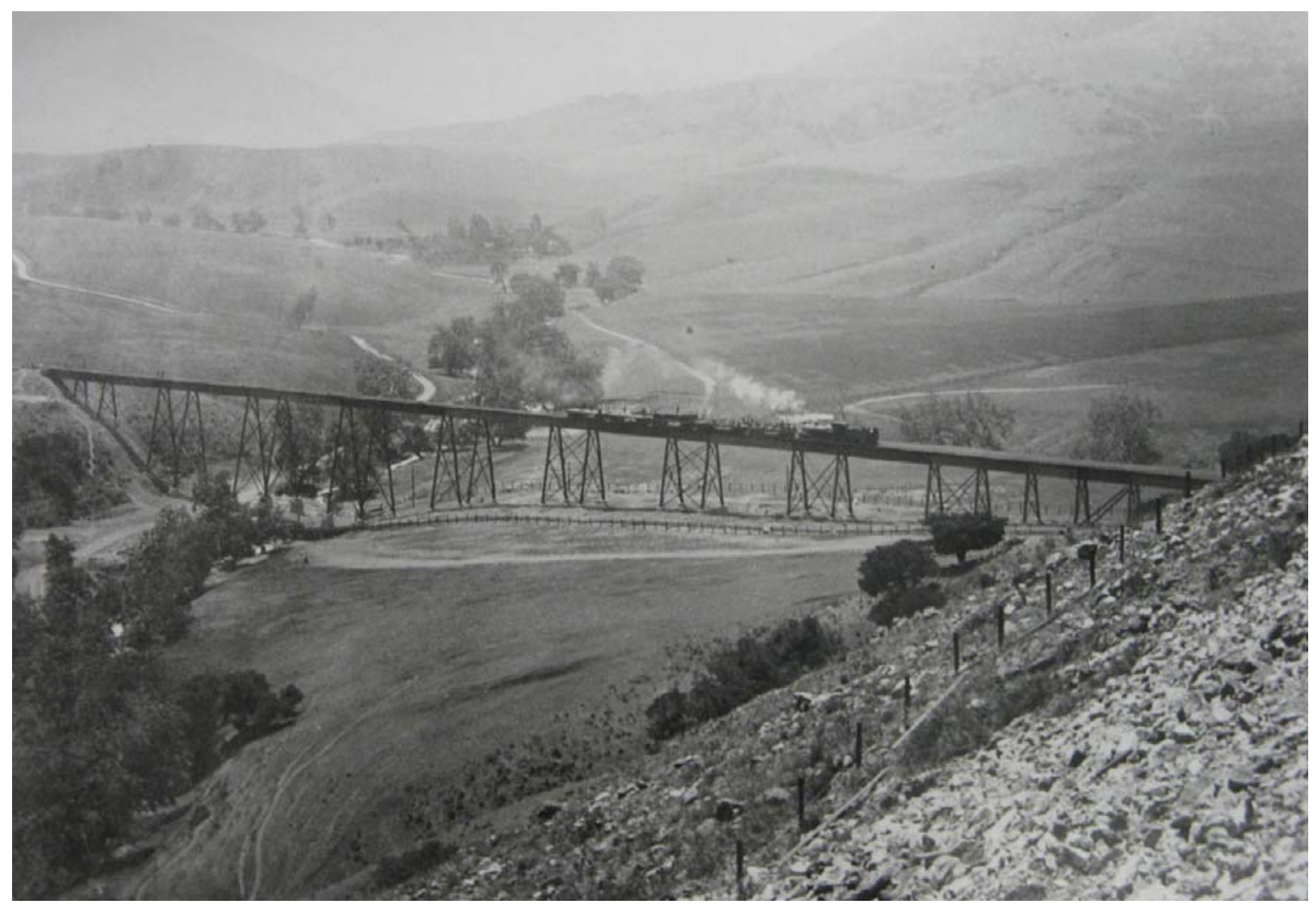

Figure 1.8: Stenner Creek Railroad Trestle Photo Courtesy of the San Luis Obispo County History Center

Unlike the Pacific Coast Railway, the Southern Pacific Railroad was a standard gauge railroad with the regulation size 56 1/2” width. This gave the Southern Pacific a significant advantage over the Pacific Coast Railway in terms of goods movement. There was no need to off-load freight to move it to a cross-country rail route heading east out of California. 


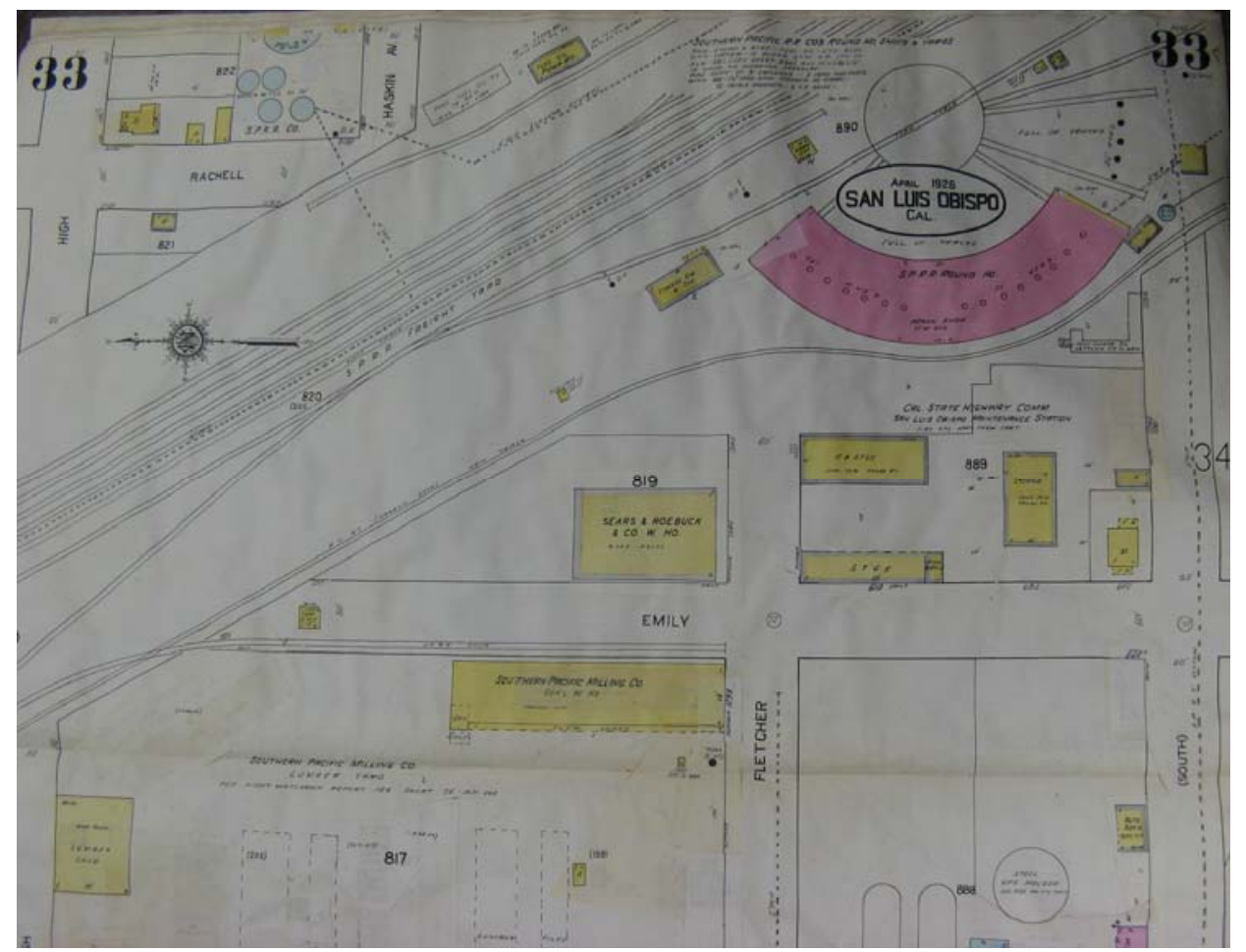

Figure 1.9: 1926 Sanborn Map with Roundhouse at Upper Right Corner Map Courtesy of the San Luis Obispo County Historic Society

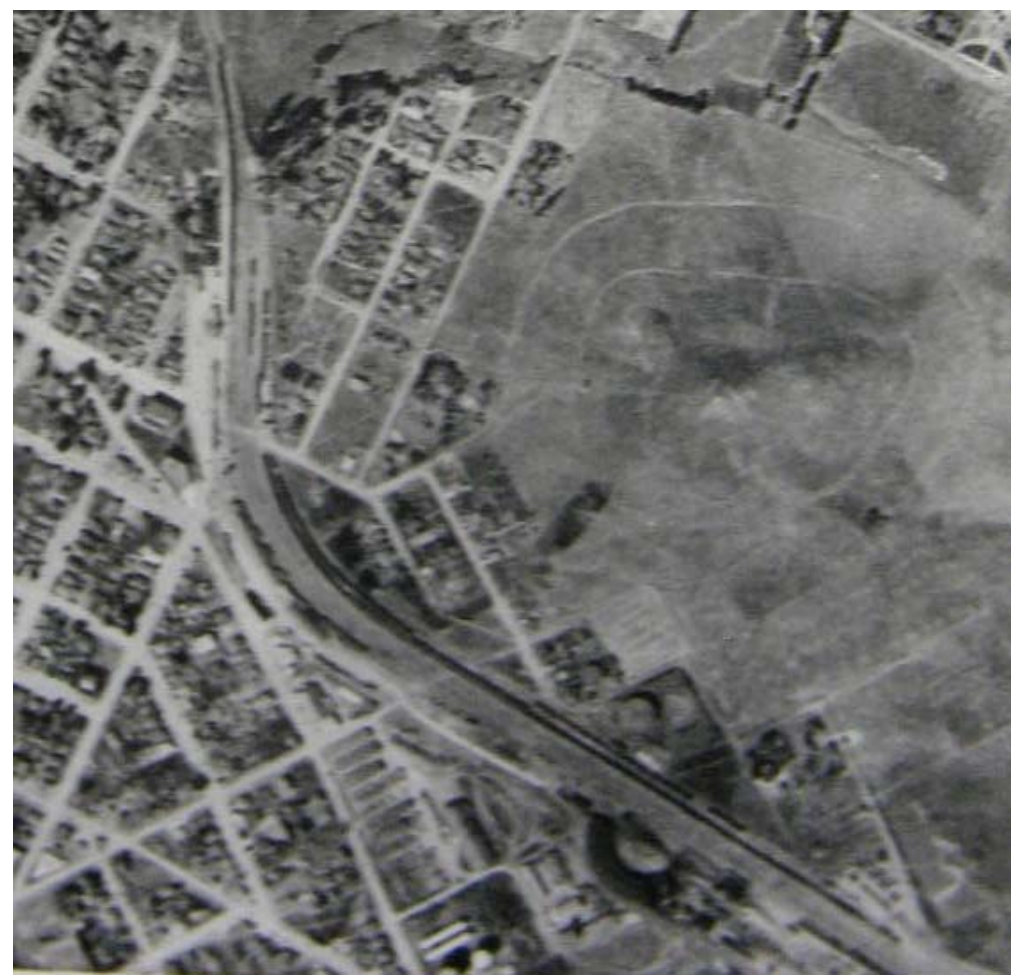

Figure 1.10: Historic Aerial Showing Roundhouse and Southern Pacific Railyards in Lower Right Corner

Photo Courtesy of the San Luis Obispo County History Center 
The new Southern Pacific Railroad made one stop at the luxurious new Ramona Hotel and then continued on to the rail yards roughly located between Broad Street and Terrace Hill and running north and south between Toro Street and Francis Street. The rail yards contained numerous buildings and rail facilities and were bisected by four sets of north/south railroad tracks (Figures 1.9 and 1.10). In addition to the main tracks, a number of spur tracks ran through the site. A set of spur tracks still run down the center of present-day Emily Street. In 1895 the Southern Pacific built a freight warehouse in its rail yard that still stands today and is currently being converted into the site of the City of San Luis Obispo Railroad Museum (Figure 1.11). Historically, it was the primary freight loading point for both the Pacific Coast Railway and the Southern Pacific.

The most notable building in the rail yard area was the roundhouse where steam engines were repaired and maintained. Workers accessed the undersides of the steam engines from a type of open basement below the main floor of the roundhouse. Another notable structure in the rail yard was a turntable that was used to turn around the heavy steam locomotives so that they could go back up the grade since there was still no rail connection to Los Angeles or anywhere south of the City of San Luis Obispo for that matter (Figure 1.12). Well into the 1990s, the turntable remained in the rail yards until it became apparent that oily water was leaking from it and contaminating the surrounding soil. Complicating matters, there was some disagreement in the community over whether to clean up the site or try and preserve it for its historic value. Due to the railroad's concern about liability, they hired a salvage company to cut up the turntable. Unfortunately, the lack of consensus over what to do with the turntable led to its demise and a lost chance to preserve the railroad's history for future generations to enjoy. Around the same time period the railroad was decommissioned and many historic artifacts were sold off. 


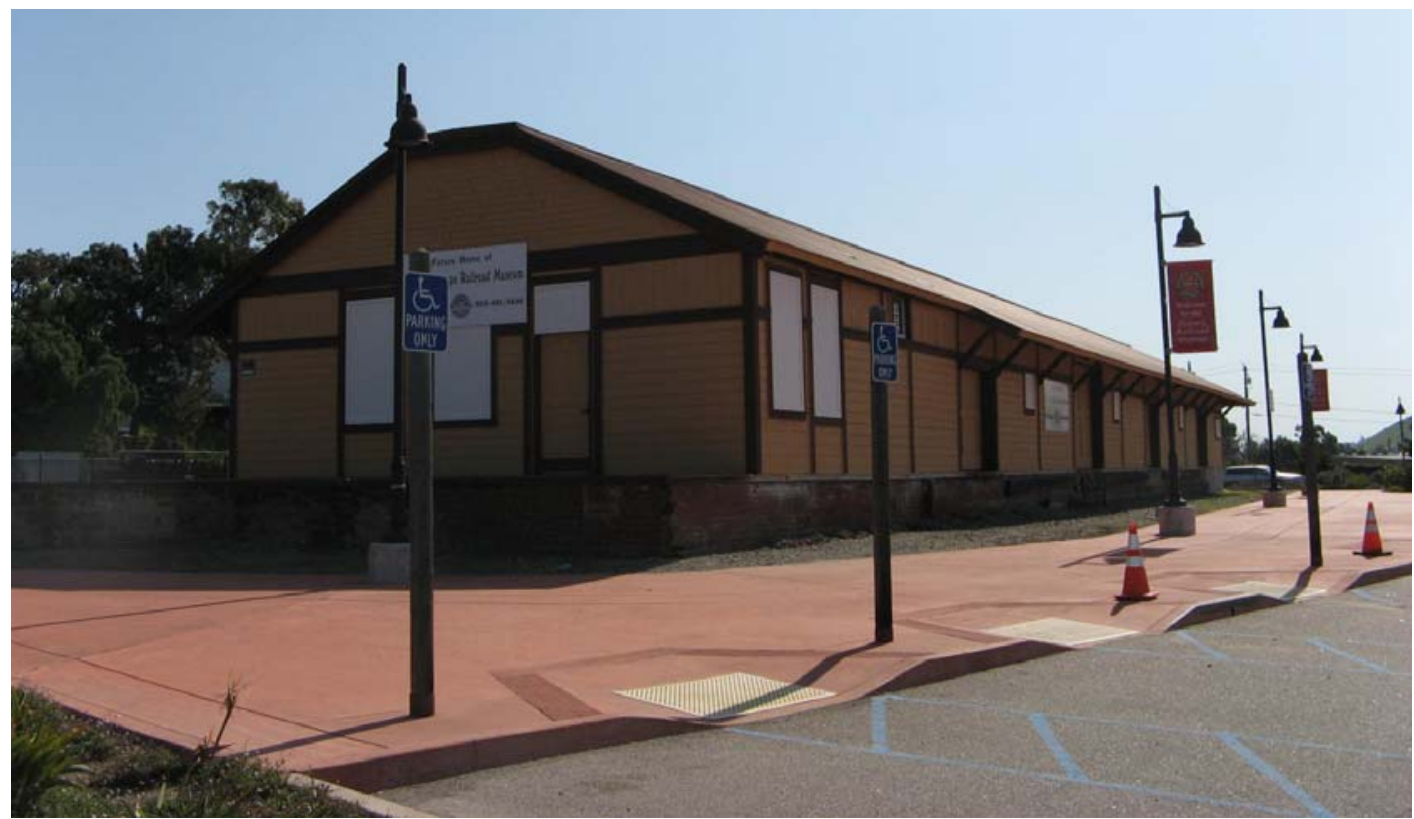

Figure 1.11: Southern Pacific 1895 Freight Warehouse Photo: Adrianna Jordan.

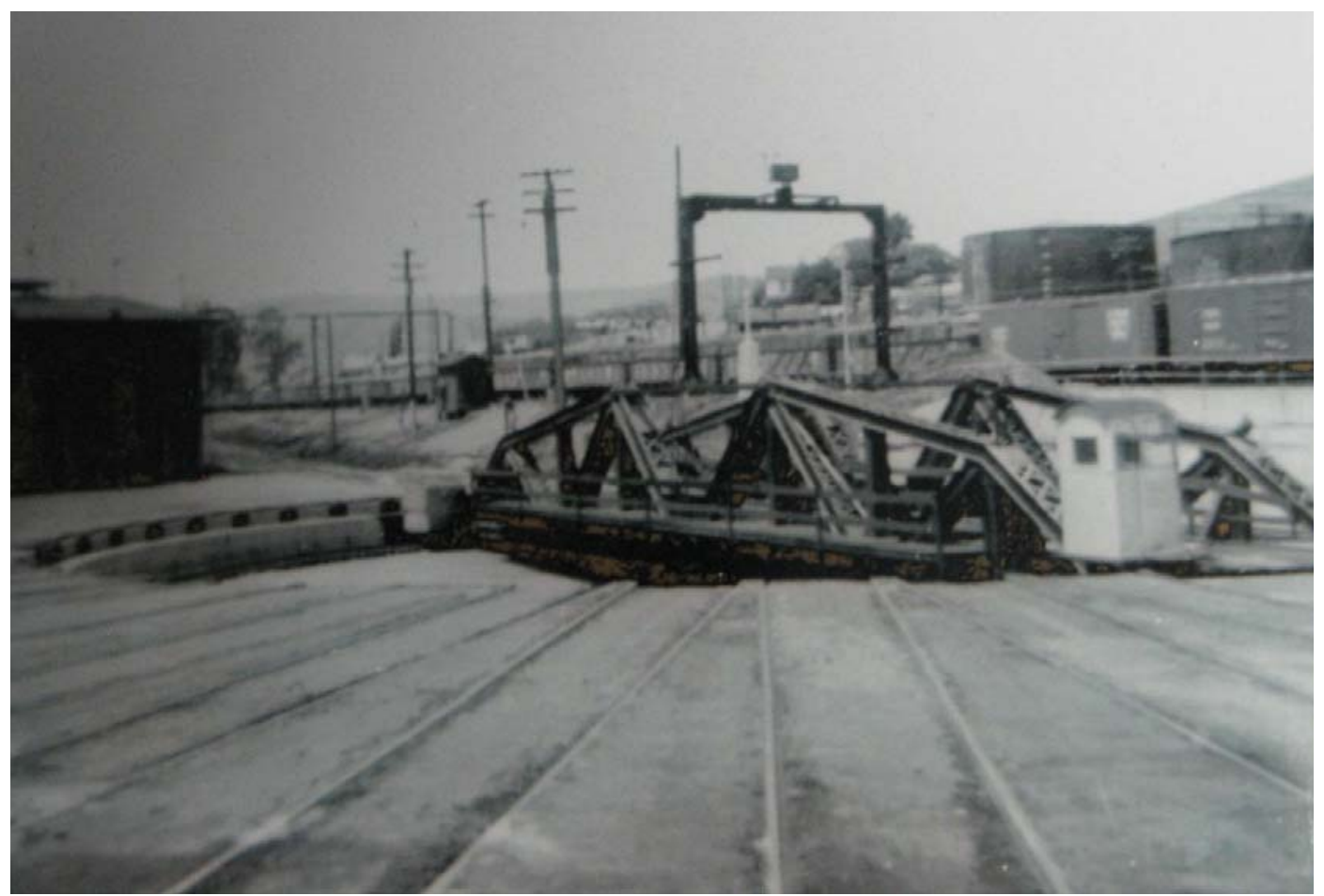

Figure 1.12: Southern Pacific Turntable

Photo Courtesy of the San Luis Obispo County History Center 
Although the vast majority of townspeople in San Luis Obispo welcomed the Southern Pacific, not everyone in turn-of-the-century California appreciated its existence. In 1901, a writer named Frank Norris published a muckraking novel about the Mussel Slough Tragedy titled "The Octopus” which was a euphemism for the Southern Pacific Railroad that was coined by the San Francisco Chronicle in 1895. The Mussel Slough Tragedy referred to a mass shooting that occurred near Hanford, California when settlers refused to vacate their improved land so that the Southern Pacific sell it for the value of the improvements. In contrast, Myron Angel wrote a "boosterific" history of the county in 1883 in anticipation of the Southern Pacific’s arrival. Regardless of positive or negative public opinion, the Southern Pacific remained a very profitable business. By 1904 it had a monthly payroll in the City of San Luis Obispo of over $\$ 20,000$, and its well-kept facilities had grown to include immense coal-bunkers, railroad shops, the roundhouse, office, warehouses, and other buildings (Source: 1904 San Luis Obispo Fire Department Souvenir).

Unfortunately, the heyday of both of the Pacific Coast Railway and the Southern Pacific was relatively short-lived as automobile transportation gained traction as the preferred mode of transporting people and freight in the $20^{\text {th }}$ century. Chapter 2 explores the demise of the railroads due to advancing technologies, cultural shifts, and economics. 


\section{Chapter 2: The Demise of the Railroads}

The global economy and changing choices for transportation transformed the local railroad industry and eventually led to its demise. Due to its physical limitations, the Pacific Coast Railway was ultimately most vulnerable to the advent of the automobile, refrigerated trucks, and the national economy, and experienced a relatively fast decline when compared to the Southern Pacific which held on for decades longer until passenger travel was moved to Amtrak and ownership of the Southern Pacific was transferred to the Union Pacific.

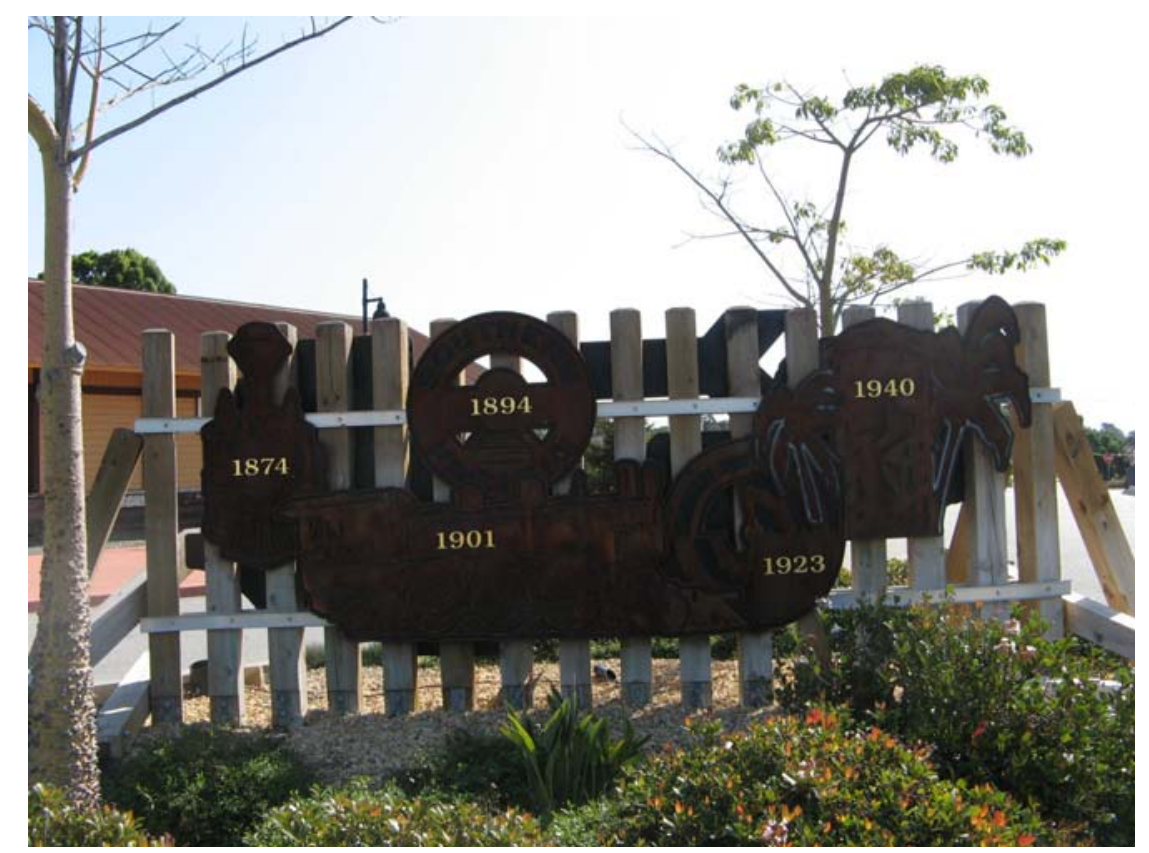

Figure 2.1: San Luis Obispo Railroad District Public Art Listing Important Dates in Railroad Evolution Photo: Adrianna Jordan. 


\section{$\underline{\text { 2.1 A Brief Timeline of Important Dates }}$}

The artwork in front of the Railroad Museum (Figure 2.1) identifies some benchmark times in railroad evolution including:

1874 - Pacific Coast Railway is founded between Avila and San Luis Obispo 1894 - Southern Pacific Railroad connects San Francisco and San Luis Obispo 1901 - Southern Pacific Railroad connects Los Angeles and San Luis Obispo 1940 - Demise of the Pacific Coast Railway; water tower built for Southern Pacific in rail yard

\subsection{Pre-World War I}

The Pacific Coast Railway and Port Harford played a major role in diversifying the economy of the City of San Luis Obispo and stimulated commerce and trade in the hinterland by enabling trade with a much larger region. Although there was access to San Francisco via the Cuesta Grade stagecoach road starting in the mid-1800s, it was impossible to transport large-scale materials on it and it was often muddy in the rainy season. Port Harford's status as an international port-of-entry meant that passengers and goods from as far away as the Pacific Rim and Europe disembarked daily at the port throughout the 1880s and 1890s. Capitalizing on the constant stream of visitors, the Ocean Hotel (later re-named the Hotel Marre) was built at the base of Harford Wharf in 1882. Unfortunately, seven years later in 1889 a near-disaster almost occurred at the port when the steam ship Queen of the Pacific sank in 22 feet of water within 500 feet of the pier. Luckily, because the ship was in shallow water, no lives were lost. In response to the incident, the Point San Luis Lighthouse Station (Figure 2.2) was constructed only one year later in 1889. 


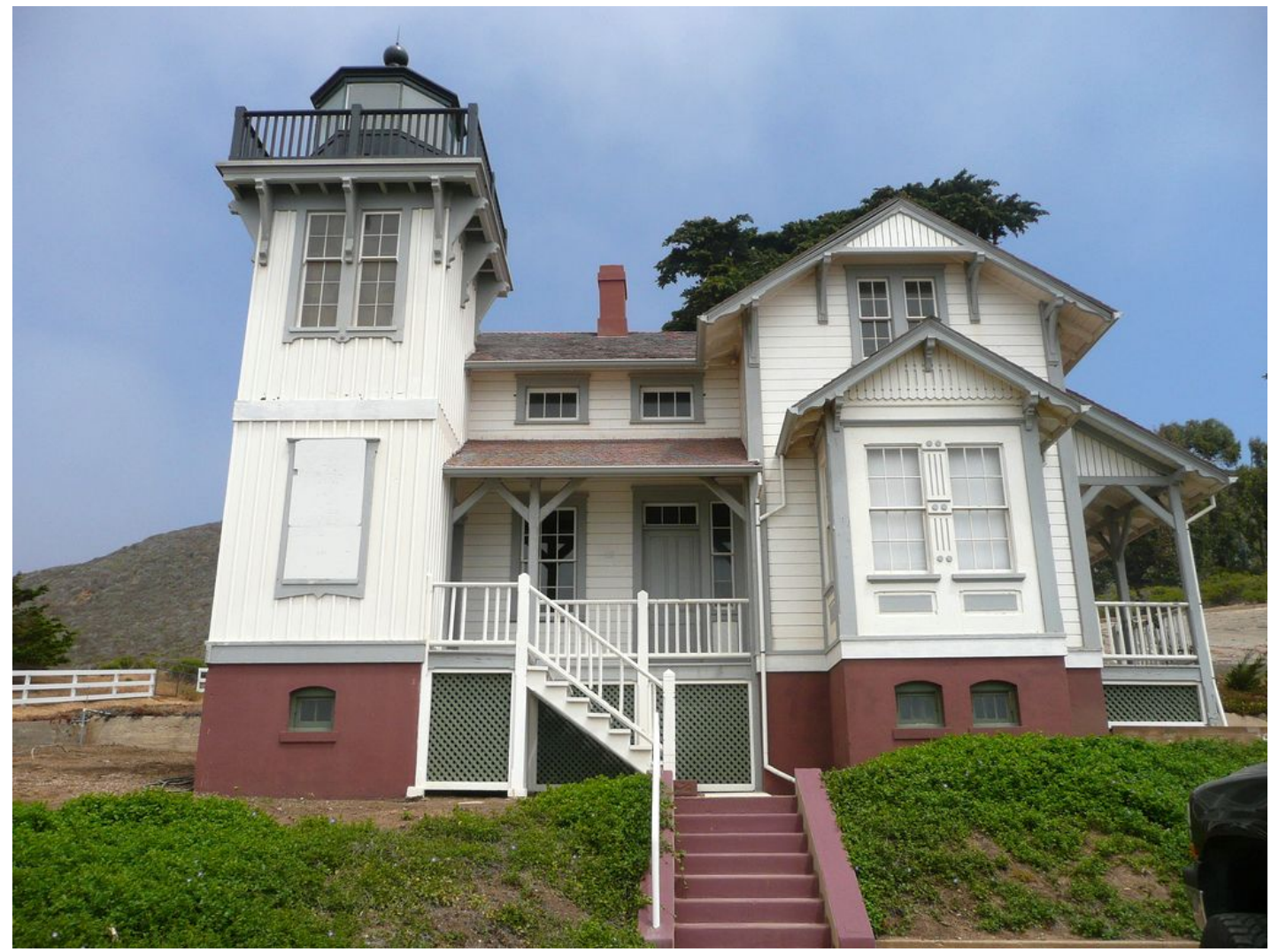

Figure 2.2: San Luis Lighthouse Station Courtesy of Lighthouse News (2011).

The arrival of the Southern Pacific in 1894 marked the beginning of a slow decline for the Pacific Coast Railway. The Southern Pacific Railroad offered lower freight rates from the City of San Luis Obispo than from other areas in Northern California so that it could compete with (and undercut) the Pacific Coast Railway. Additionally, all-railroad freight routes such as the Southern Pacific's tracks may have been viewed as a more reliable form of transportation since they were not as dependent on good weather as the steam ship route. Nonetheless, the Pacific Coast Railway and Port Harford moved forward with facility improvements.

Around the turn of the century the Pacific Coast Railway constructed two sets of spur tracks to Bishop’s Peak in San Luis Obispo so that it could transport stone from a rock quarry to the 
construction site of the breakwater at Port Harford. The quarry was founded by Dr. G.B. Nichols who purchased land on the southwestern slope of Bishop’s Peak. “A large pulley was placed at the quarry and a heavy, flexible cable fed through the pulley. The cable ends were each attached to a small railroad car. One car was loaded with stone and rolled down the slope, thereby pulling the other railroad car up the hill to the quarry for loading - no power required!” (Parsons, 1995) Due to meager congressional appropriations, this transport method was abandoned and the quarry eventually failed as a business (San Luis Obispo Morning Tribune, 1905). Despite the additional improvements, by the early 1900s Port Harford had lost most of its general shipping business and focused almost exclusively on exporting petroleum, which arrived via the 1906 Union Oil pipeline from Coalinga, in Fresno County, California. A couple years later, in 1908 the US Navy’s “Great White Fleet” anchored in San Luis Bay en route to complete its 1907-1909 circumnavigation of the globe in an effort to demonstrate the United State's blue water prowess. In response, the Pacific Coast Railway ran special excursion trains to Avila to bring in spectators (Krieger, 1989).

In an attempt to become more competitive, the Pacific Coast Railway created a spur line to the Southern Pacific Railroad Depot along what is now South Street to facilitate the direct transfer of goods and passengers in either direction. "However, by 1913 only a single daily mixed train (passenger and freight) ran between the Port and San Luis Obispo” (Rice, 2006).

During this same period, many of the Southern Pacific’s important structures were constructed (Figure 2.3), and between 1906 and 1926 both a Signal Repair shop and the Southern Pacific’s Transportation Company Building were built. The Signal Repair shop was located across from 
the present-day depot, and the Transportation Company building (located near the "Railroad Square" call-out in Figure 2.4) is still used today by Union Pacific but is in a state of minor neglect.

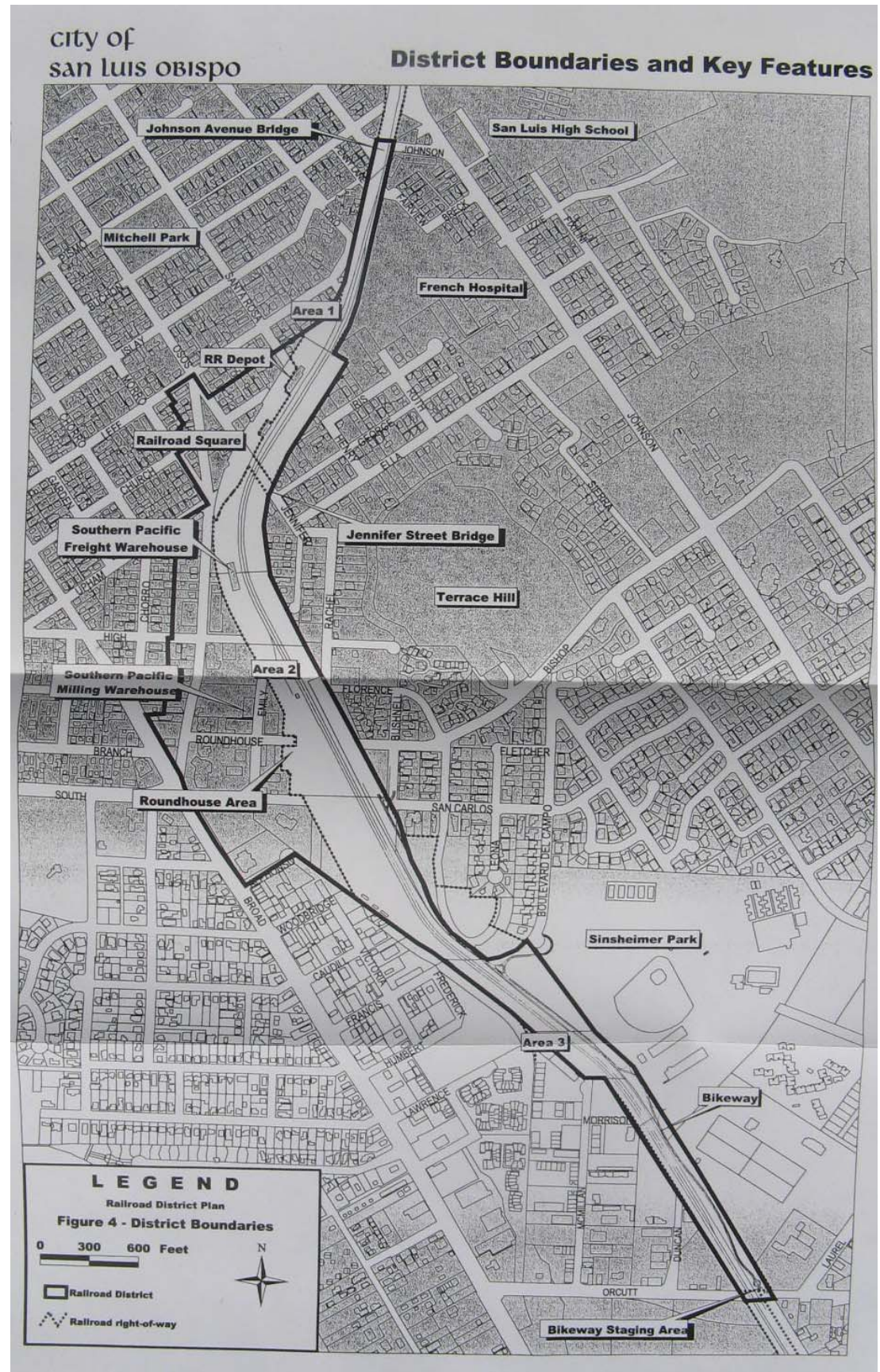

Figure 2.3: The Present-Day Layout of the Union Pacific Railyard Map Courtesy of the City of San Luis Obispo Railroad District Plan (1998). 


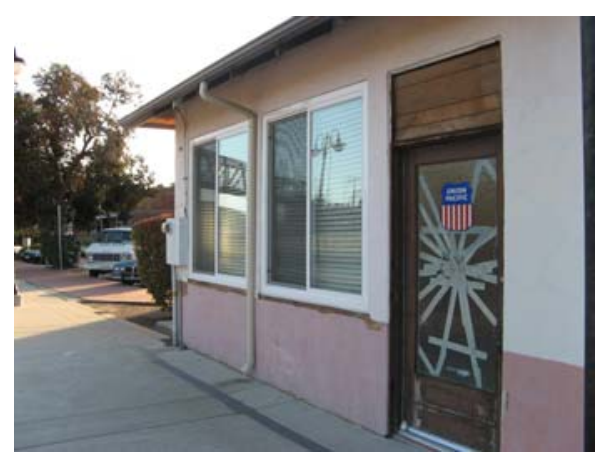

Figure 2.4: The Southern Pacific Transportation Company Building Photo: Adrianna Jordan.

\subsection{World War I to World War II}

As the automobile gained popularity as the de facto transportation mode of choice for community members who could afford it during the "Roaring '20s", it became apparent that local roads were woefully inadequate to handle the new form of transportation. Therefore, in the 1920s, a series of operational improvements were made to the Cuesta Grade Road, and additional road linkages to the south of the City of San Luis Obispo were also improved. Unfortunately, these improvements had the downside of chipping away more of the railroad's customer base as people chose to drive rather than take the train.

As the city of San Luis Obispo headed into the 1930s, the Great Depression hit. Suddenly, most families could not afford to travel for leisure, regardless of the mode of travel. The rail industry suffered as a result. “As revenues declined passenger service all but disappeared, freight schedules became infrequent and trackage was reduced. Further, the physical plant and rolling stock not only was rapidly becoming obsolete but was worn out after years of deferred service” (Rice 2006). However, the necessity to move troops and the changing economic realities of the 
forthcoming war would provide a brief respite for at least the Southern Pacific, even if by this time it was too late for the Pacific Coast Railway.

During World War II, passenger traffic on the Southern Pacific reached all-time record highs. In 1940 up to 10 passenger trains per day were stopping in the City of San Luis Obispo. Partly this is due to the fact that most local troops were transported by train to San Miguel before continuing on to Camp Roberts which was established that same year specifically to train troops for World War II combat. Additionally, during the war years, gas and rubber were rationed and therefore people were more likely to take the train for long-distance travel than to take their personal automobiles. Furthermore, train travel and car sharing were seen as more patriotic forms of transportation than the single-family automobile (Figure 2.5). Flush with revenue, the Southern Pacific continued to make improvements to its facilities in the City of San Luis Obispo first adding a water tower in 1940, and then in 1942 building the "Spanish Colonial" style Passenger Depot which is still in use today as the Amtrak Station. 


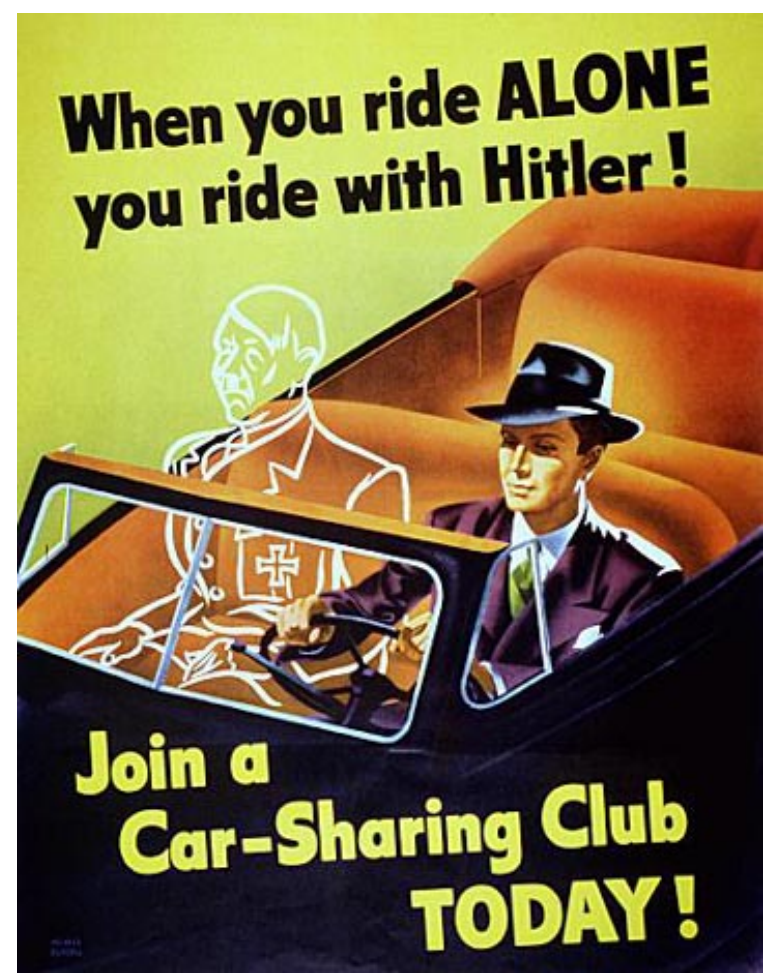

Figure 2.5: American World War II Propaganda Encouraging Citizens Not to Drive Alone Courtesy of US National Archives (2011).

Despite the nationwide record numbers of rail riders, ridership on the Pacific Coast Railway continued to suffer. In the early 1930s, ironically aided by the Pacific Coast Railway which carried road building materials shipped in via Port San Luis, the legendary Pacific Coast Highway and Highway 101 were completed through San Luis Obispo County. The new access to the coast meant that it was now easier to get to Avila via automobile than via train. This was the final death knell for the Pacific Coast Railway. By1940 the Pacific Coast Railway was suffering from a \$1 million deficit. “On December 20, 1941 the Pacific Coast Railway received government authorization to abandon its remaining trackage... The railway's last whistle sounded when on February 28, 1942 the ten miles of line between San Luis Obispo and the Port was sold to the Port San Luis Transportation Company” headed by Elton Tognazzini for a sum of $\$ 17,265$. That company ceased operations on October 29, 1942 (Rice, 2006). Meanwhile, the 
train equipment was sold to A. Feher and Sons (with exception to the train coaches destroyed during the 1935 filming of Diamond Jim Brady). A mere decade later most remnants of the Pacific Coast Railway had completely disappeared.

The Port itself fared better than its Pacific Coast Railway counterpart, and by World War II it was the largest crude oil shipping port in the world. Due to its strategic vulnerability, the Port was provided with naval protection during both wars. "From 1917 to 1918 a full company of infantry was stationed at the Union Oil Tank Farm operation in San Luis Obispo, while units of the Coast Artillery guarded the Point San Luis-Point Buchon area. Artillery and cavalry units also patrolled the cliffs and beaches during the panic-stricken days following the attack on Pearl Harbor. Between 90 and 300 men reinforced the Coast Guard detachment at the lighthouse, from 1941 to $1943 ”$ (Krieger, 1989).

\subsection{The Postwar Period}

During and after the war, the Southern Pacific set out to improve its capital rolling stock and spent most of the mid to late 1940s replacing its steam locomotives with diesel electric locomotives. Engine 4449 was one of the last streamline steam engines based in the City of San Luis Obispo and remained in operation through the 1940s. After it was decommissioned, it ended up in Portland, Oregon. On rare occasions, it is still operated for special events. The last steam locomotive in operation on the Coast Route was decommissioned in 1956. 
As goods movement declined at Port San Luis through the post-war period, it became known more for fishing and recreation. In 1954, county residents voted to create the Port San Luis Harbor District which bought Tognazzini's property and the pier in 1964. The purpose of creating the Harbor District was to fix up the aging facilities and increase ocean-driven commerce. Unfortunately, oil leaking from the pipeline that Unocal had built years earlier had been slowly seeping into the harbor. Finally, in the late 1990s, Unocal transported 6,750 truckloads of contaminated material to the Bakersfield Landfill in Kern County and replaced it with sand from the Guadalupe Dunes. The half mile wide excavation necessitated the razing and redevelopment of the oceanfront portion of the beach community. It also enabled construction of the new vacation homes, shops, and restaurants that now front the ocean and are billed as a regional tourist attraction.

At roughly the same time that Unocal began its clean-up of Avila Beach; the financially troubled Southern Pacific Railroad was merged with, and took the name of, Union Pacific Railroad in 1995. This acquisition had actually been started back in 1901; however, a divestiture was ordered in 1913. By the time that the merger occurred, daily passenger trains in the City of San Luis Obispo had dwindled to six total trains and had been operated by Amtrak since 1971. Currently, the six daily passenger trains include two southbound Pacific Surfliner trains, two northbound Pacific Surfliner trains, one Coast Starlight southbound train, and one Coast Starlight northbound train. Through the years, neglect has taken its toll on the passenger rail facilities and although it took approximately 10 hours in the 1950s to make the trip between Oakland, California and Los Angeles, California, it now takes 12 hours to complete the trip. 
The decline of the railroads in general can be correlated to the rise of the automobile as the preferred mode of travel. This decline follows the creation of the interstate freeway system which revolutionized the geography of central places throughout the nation. The automobile brought with it personal freedom for individuals and families to chose when, how, and where to travel. The mobility it gave to Americans and the way of life the automobile represented was the envy of the world, and emerging and established nations sought to emulate the American ideal. By the 1980’s, passenger rail traffic stopping in the City of San Luis Obispo had decreased to insignificance, even though Caltrans records show an increase in overall Surfliner ridership during the same period (California Department of Transportation, 2008), resulting in a decline of neighborhoods surrounding the station. The area’s gradual slide into obscurity attracted the city’s attention in the 1990’s and a major effort was undertaken to create new opportunities for reinvestment in sites adjacent to, and near, the rail tracks.

Indubitably, the automobile had dire consequences for the railroad industry and reshaped the way that people traveled and shipped freight. Chapter 3 explores how the advent of the railroad literally reshaped the layout of land in the City of San Luis Obispo, and how newer forms of transportation learned to co-exist with the railroads once safety issues were resolved through alterations in the city form. 


\section{Chapter 3: City Fabric}

The railroads' heyday and the impact it left on the landscape of the city, as well as the railroad's significant influence on land use, safety, and social stratification are explored in this chapter.

\subsection{Historic Shifts in the Street Grid}

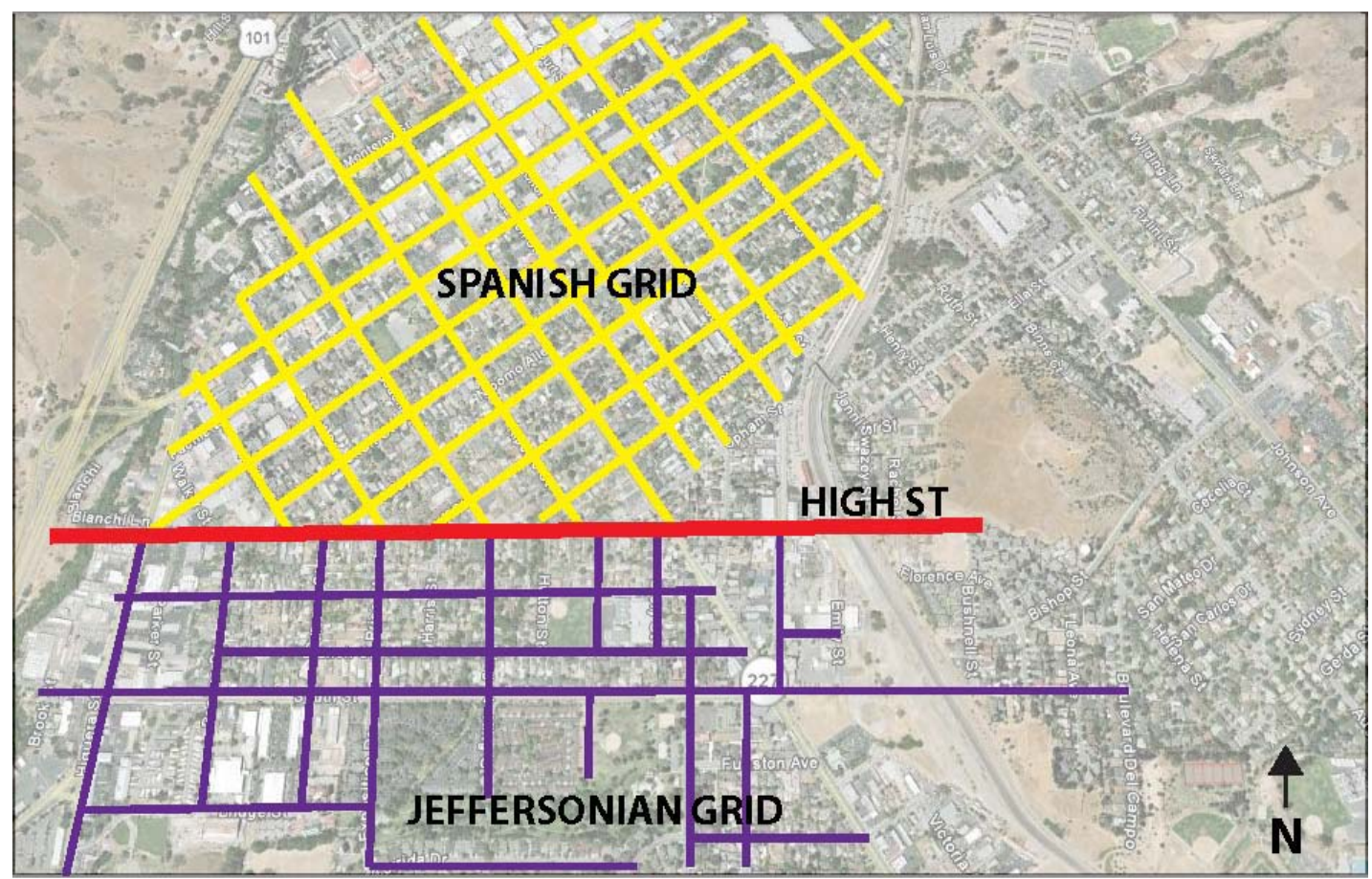

Figure 3.1: Shift in the city's grid at High Street.

Graphic: Adrianna Jordan.

Before the first train whistle was ever heard in San Luis Obispo the city's street grid had already undergone a number of changes that owed more to the societal customs and politics of various eras than to topographic necessity. When the original mission town was plotted under Spanish rule in 1772, the street axis was designed according to the Spanish Grid which is rotated approximately 26 degrees off of the north/south axis (Figure 3.1). This orientation provides access on every street to both light and heat in the winter. In the summer, the streets receive shade and shadows for the majority of the day except for two brief periods in mid-morning and 
mid-afternoon (Knowles, 1999). The pattern of sunlight and shadow in the downtown is also advantageous for commercial development because it allows developers to build taller buildings without casting the sidewalks and streets in shadows. In contrast, the newer end of the city, located just south of High Street and plotted in the years after the U.S. took over control of California in 1847, was designed along a straight north/south and east/west axis in accordance with a Jeffersonian Grid. "Jefferson's plan, set down in the Land Ordinance of 1785, reflected the rational spirit of the time and not the implications of natural topography. Discarding the traditional surveying concept of 'metes and bounds' (which took natural features of the land into account), he designed a strict grid system.” (US Gen Net, 2011). Unfortunately, unlike the Spanish Grid, the Jeffersonian Grid creates large shadows on streets in the winter and provides less shade in the summer (Figure 3.2). Newer subdivisions plotted using the Jeffersonian Grid include Weil's Addition (1887), Southside Addition (1891), Norton Addition (1901), and Bonita Terrace (1951).

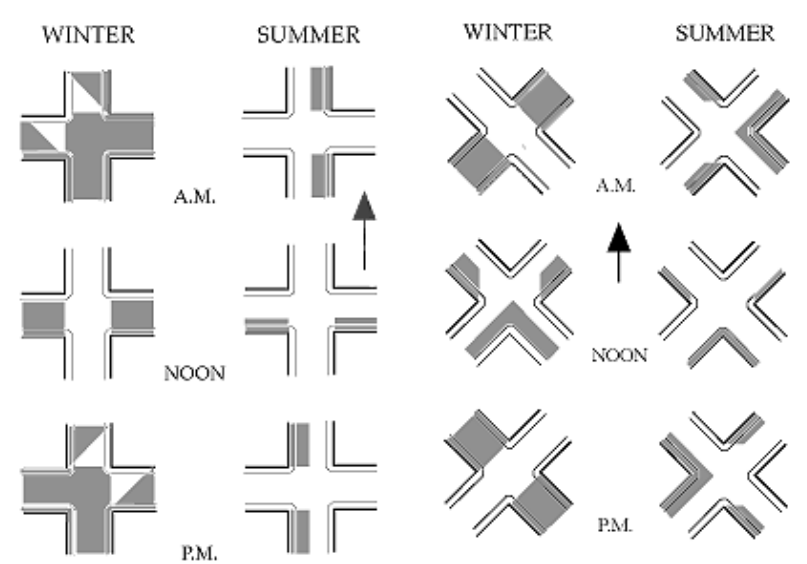

Figure 3.2: Street shadow patterns in a Jeffersonian Grid (left) and a Spanish Grid (right) Courtesy of US Gen Net (2011). 


\subsection{The City's Residential Expansion}

The arrival of the railroad, in particular the Southern Pacific, helped open up new residential areas in the City of San Luis Obispo. Residential tracts developed between 1874 and 1894 are noted and located on the map (Figure 3.3), and illustrate the ring growth that occurred around the city core in this period. The map of land annexations between 1874 and 1891 clearly illustrates a pattern of land speculation adjacent to and overlapping the Southern Pacific railroad track rightof-way, and a general shift in new residential development towards the eastern and southern limits of the city.

The land annexations are coded by number on the map and correspond to the chronology list below:

1. Phillips Addition (1874)

2. Deleissigues Tract (1876)

3. Buena Vista Tract (1885)

4. Loomis Tract (1887)

5. Deleissigues Subdivision (1887)

6. McBride Tract (1887),

7. Homestead Tract (1887)

8. Hathway Addition (1887)

9. Buena Vista Addition (1887)

10. Fairview Addition (1887)

11. Deleissigues Addition (Block 5) (1887)

12. Central Addition (1888)

13. Maymont Addition (1889)

14. Scwartz Addition (1889)

15. South Side Addition (1891)

16. Imperial Addition (1891)

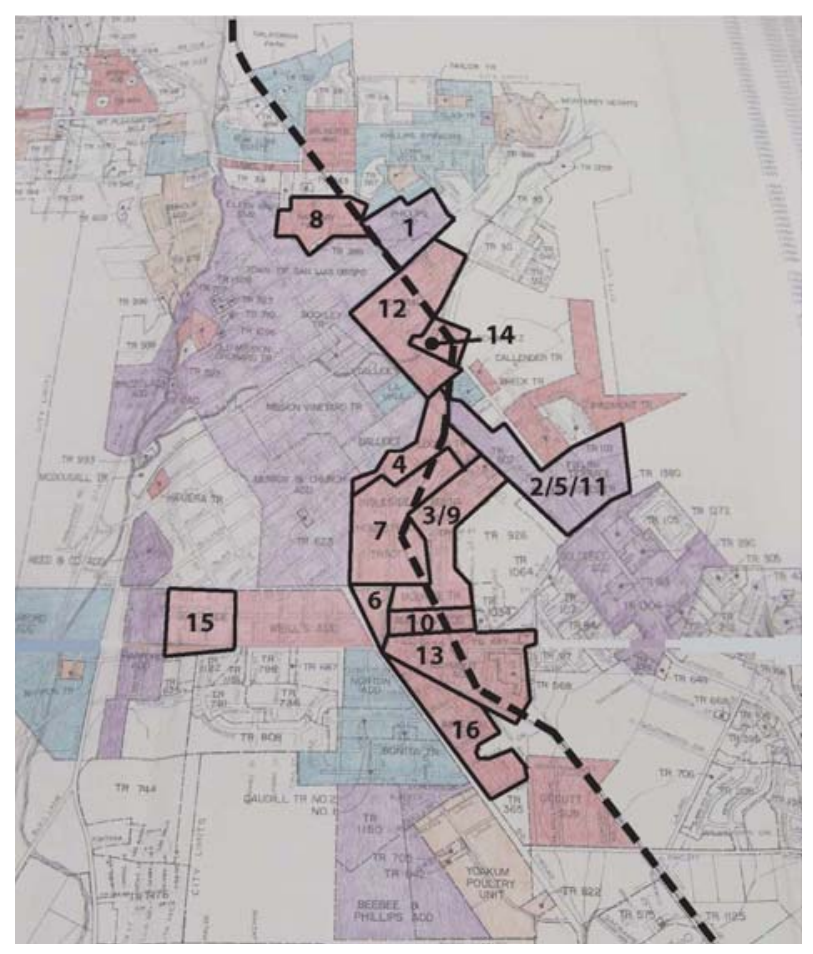

Figure 3.3: 1874-1891 Land Annexations Around the Proposed Right of Way of the Southern Pacific Railroad Graphic: Adrianna Jordan; basemap courtesy of the City of San Luis Obispo 
Most of the Pacific Coast and Southern Pacific railroad workers living in the City of San Luis Obispo at the turn of the century who could afford it chose to locate their families in downtown San Luis Obispo. Echoing modern real-estate patterns, the older neighborhoods on the Spanish Grid had a much higher prevalence of occupancy by railroad managers, conductors, and engineers - especially if they were also at a higher elevation than the railroad tracks. Meanwhile, the newer subdivisions on the south end of town closer to the railroad tracks were typically occupied by working or middle class railroad families.

Overall, the majority of the new subdivisions annexed by the city between 1874 and 1891 attracted mostly working class railroad workers. However, turn-of-the-century telephone directories that list occupations and addresses, as well as the general size of plots of land within the subdivisions reveal that the Deleissigues Addition was solidly middle class in composition (Figures 3.4). In addition, the Loomis Tract and McBride Tract were popular with both middle and working class families, most likely because they were within walking distance of both the downtown and the Southern Pacific rail yard and service facilities. 


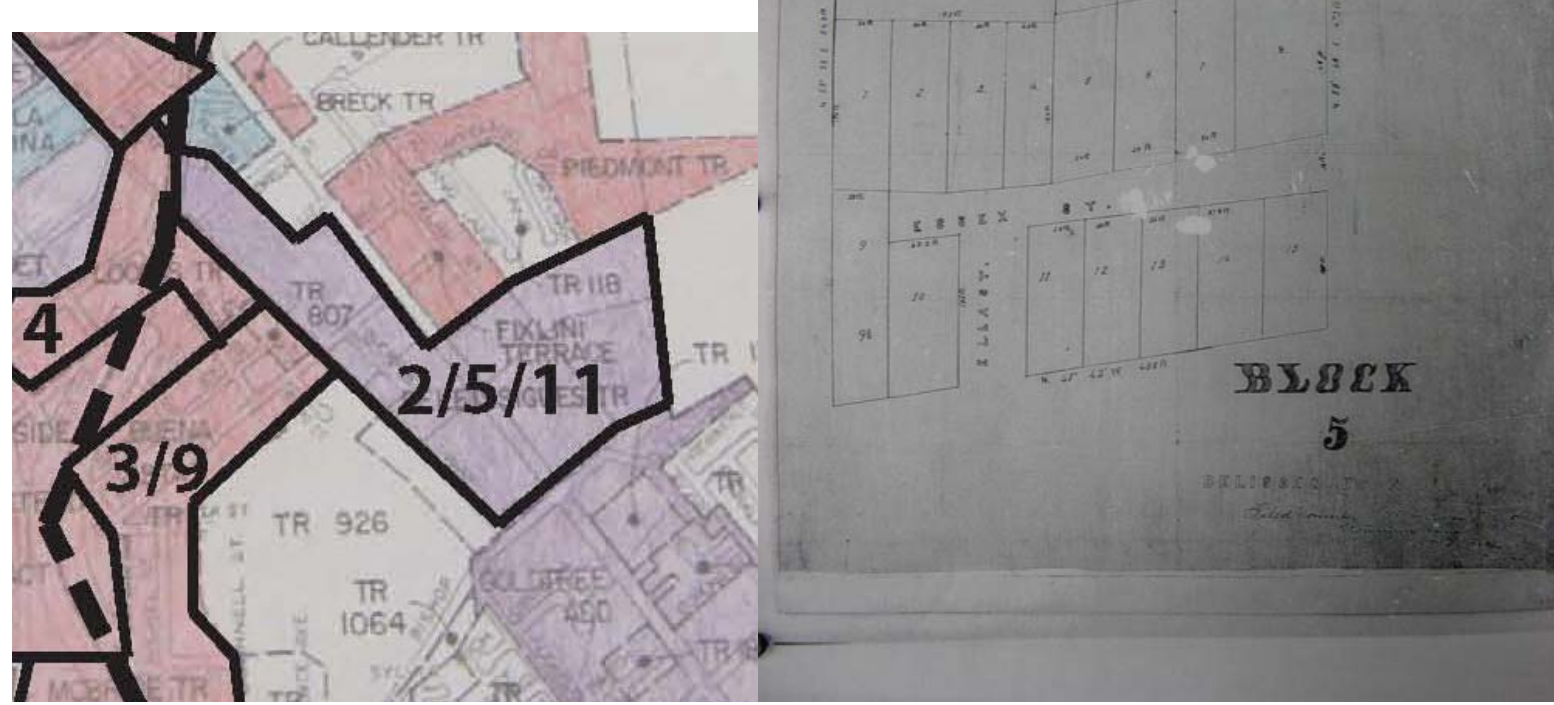

Figure 3.4: 1887 - Deleissigues Addition (block 5). Labeled Nos. 2/5/11 on left map. Graphic: Adrianna Jordan; basemaps courtesy of the City of San Luis Obispo 


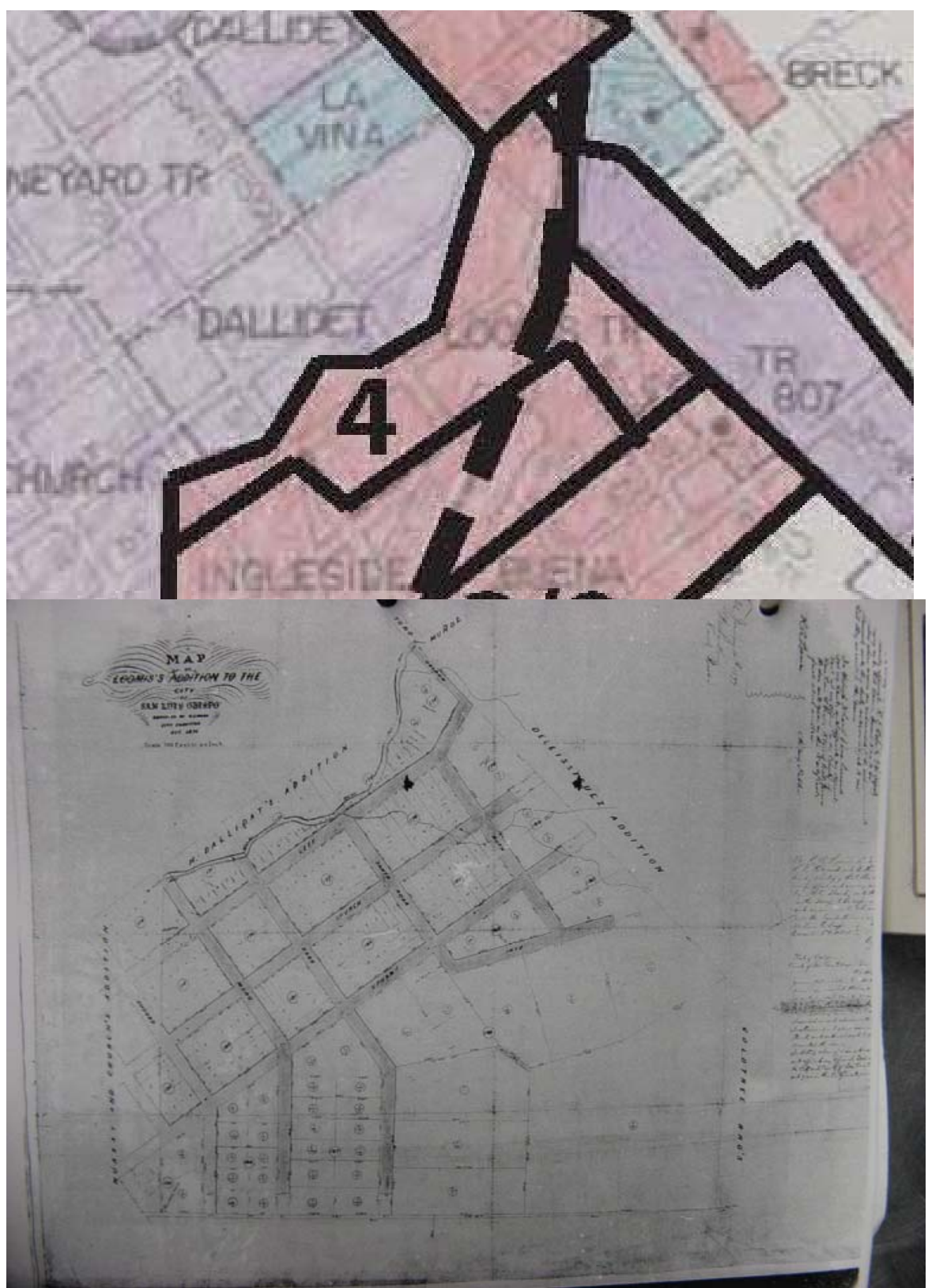

Figure 3.5: 1887 - Loomis Tract. Labeled No. 4 on upper map.

Graphic: Adrianna Jordan; basemaps courtesy of the City of San Luis Obispo 


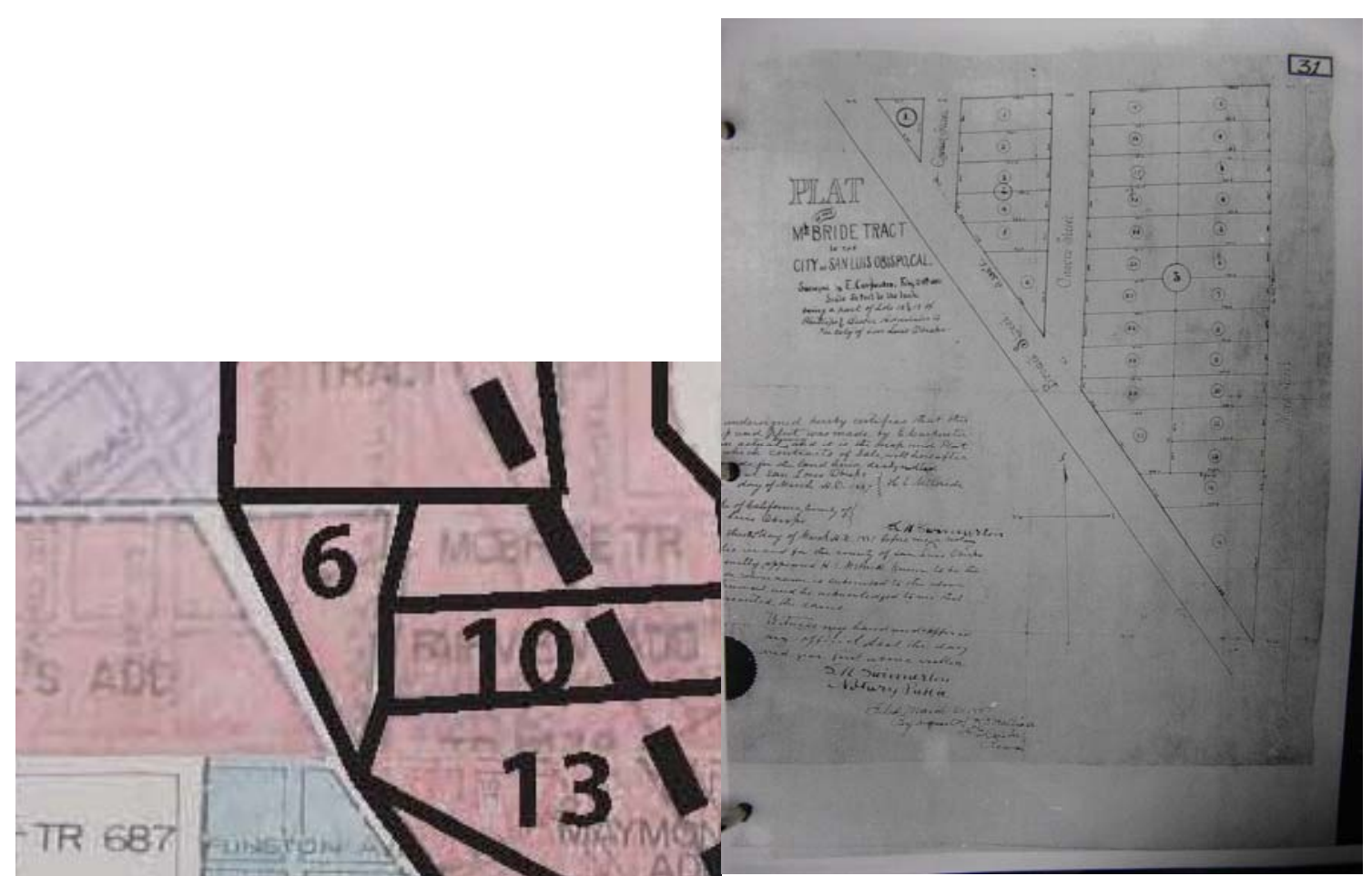

Figure 3.6: 1887 - McBride Tract. Labeled No. 6 on left map.

Graphic: Adrianna Jordan; basemaps courtesy of the City of San Luis Obispo

Based on the professional occupations settled in the neighborhood by 1904, as well as the layout, large parcel size, and elevation of the subdivision above the soot and noise of the railroad yards, the Buena Vista Addition (Figure 3.7) was most likely upper middle class in nature and by far, the nicest of the newly annexed areas of the city. 


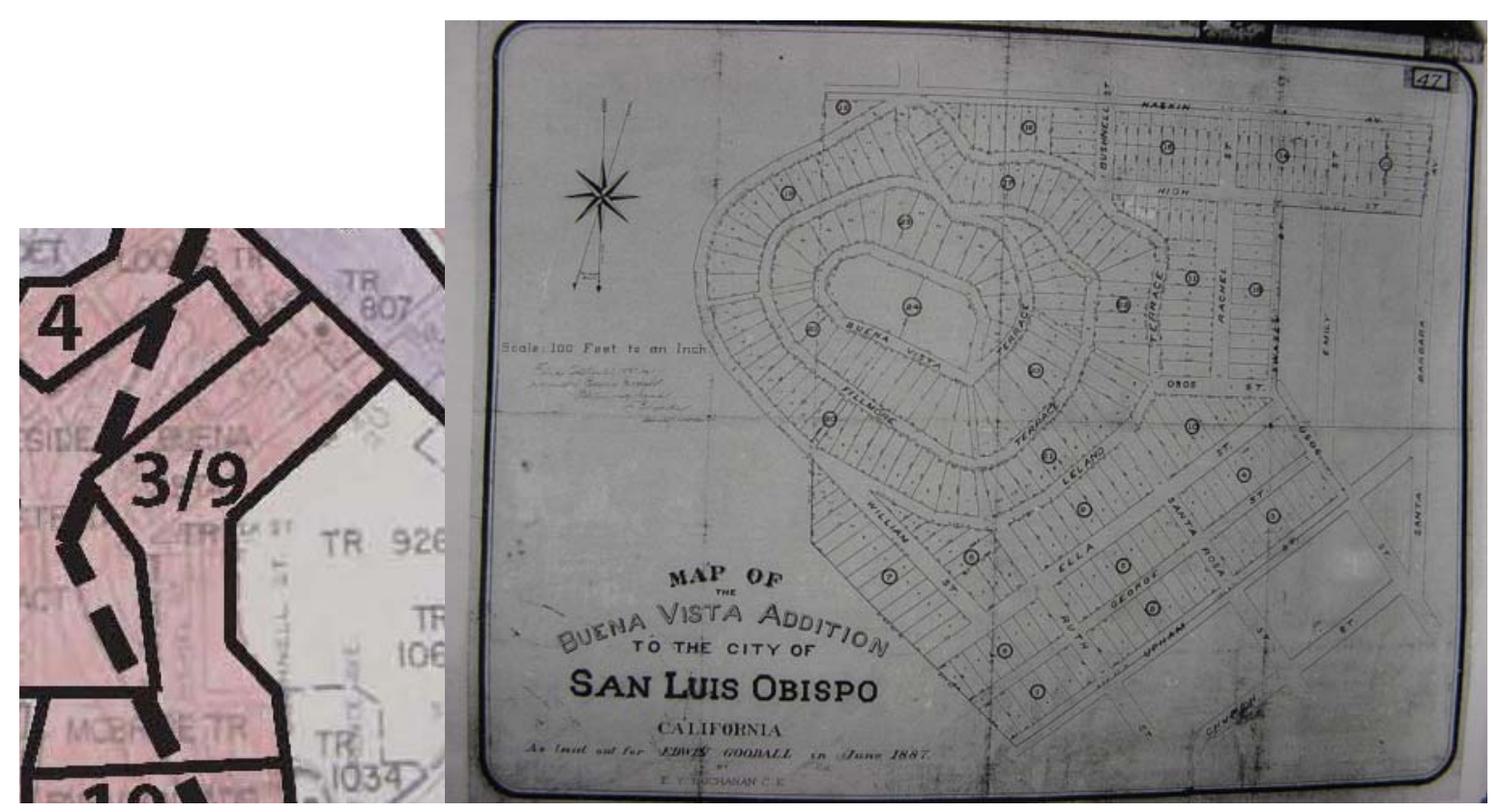

Figure 3.7: 1887 - Buena Vista Addition. Labeled Nos. 3/9 on left map. Graphic: Adrianna Jordan; basemaps courtesy of the City of San Luis Obispo

Much like the Buena Vista Addition, the majority of the subdivisions in the city were approved in 1887. That same year, the mainline of the Pacific Coast Railway reached Los Olivos in Santa Barbara County, marking the farthest geographical extent of the railroad. This was the peak period of the Pacific Coast Railway, at the time the dominant means of moving people and goods throughout the Central Coast region.

\subsection{City Plats, Street Configurations, and the Southern Pacific}

In addition to spurring the development of brand new subdivisions, the Southern Pacific also destroyed and reconfigured the existing fabric of the city by barreling straight through existing and up-and-coming neighborhoods, and cutting off streets and other access routes, essentially splitting the city in half. 
The Central Addition provides one example of the dramatic effect that the railroad right-of-way had on the existing configuration of land in the city. The Central Addition had to be completely re-platted when the Southern Pacific routed the railroad directly through it, effectively cutting the eastern end of the city in half and creating dangerous at-grade crossings for people living on the "wrong" eastern side of the tracks.

One the original at-grade crossings was located at Osos Street. According to the 1921 Pacific Reporter, around 5:30 pm on the evening of November 20, 1917, a local resident named Harry Green was walking his bicycle across the tracks at Osos when he was struck by a "gondola" car (an open-top type of rolling stock that is used for carrying loose bulk materials) and killed on his way to his home on the east side from his workplace on the west side of town (Pacific Reporter, 1921). Decades later, a local story claims that two World War II GIs who were home on leave were driving with their girlfriends across the railroad on Osos Street when their car stalled and they were hit and killed by a train. Following this incident, most of the remaining at-grade crossings, including Osos Street, were permanently closed. Despite significant advances in the safety of the city's railroad crossings over the last 50 years, the decisions made by the railroad's financiers in the $19^{\text {th }}$ century continue to create controversy and impact the local transportation infrastructure. On July 19 ${ }^{\text {th }}$, 2011, “the San Luis Obispo City Council unanimously approved changes to the lane configuration on Johnson Avenue near the Union Pacific Railroad bridge” over the objections of former Mayor Dave Romero who believes that moving the left-turn lane up to the light will create gridlock (Cornejo, 2011). 


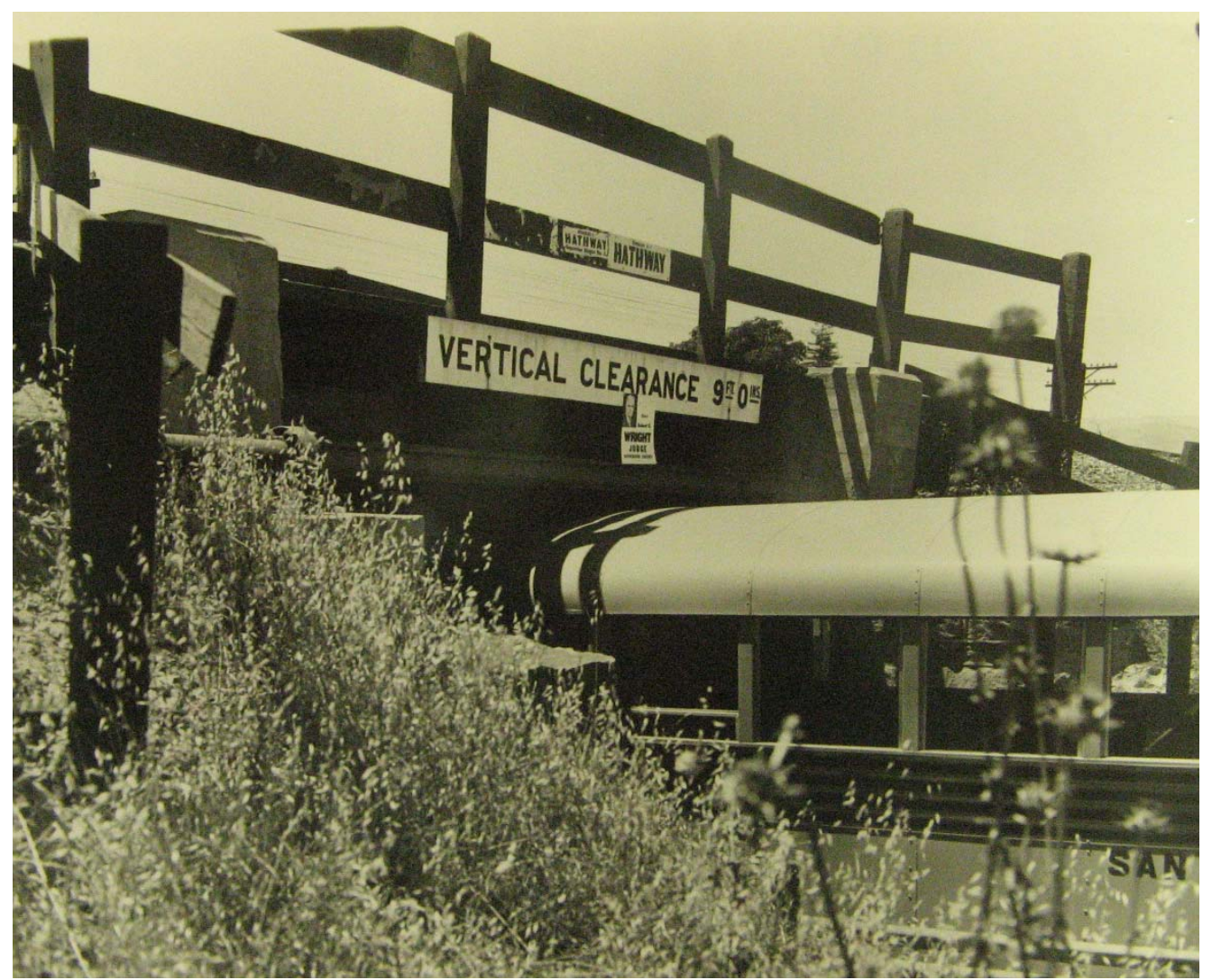

Figure 3.8: Original Johnson Avenue Railroad Bridge Undercrossing shown just before it was replaced with a wider undercrossing in 1958. Photo Courtesy of San Luis Obispo County History Center.

Although the safety of getting between the west side and east side of town has increased substantially with the elimination of the most dangerous at-grade crossings, and the creation of under-passes such as the Johnson Avenue bridge (Figure 3.8) and over-passes such as the Jennifer Street Bridge, the demarcation of what is considered close to downtown (west) and what is not, (east) of the railroad continues to linger today. The railroad affected the Loomis Tract parcel configurations in the present-day blocks between Upham, Morro, Osos, and Leff, transforming them from the original grid plan (Figures 3.9 and 3.10). Today this reconfiguration lends an unpredictability and charm to the city fabric in that area of town and helps to attract new residents to the district. 

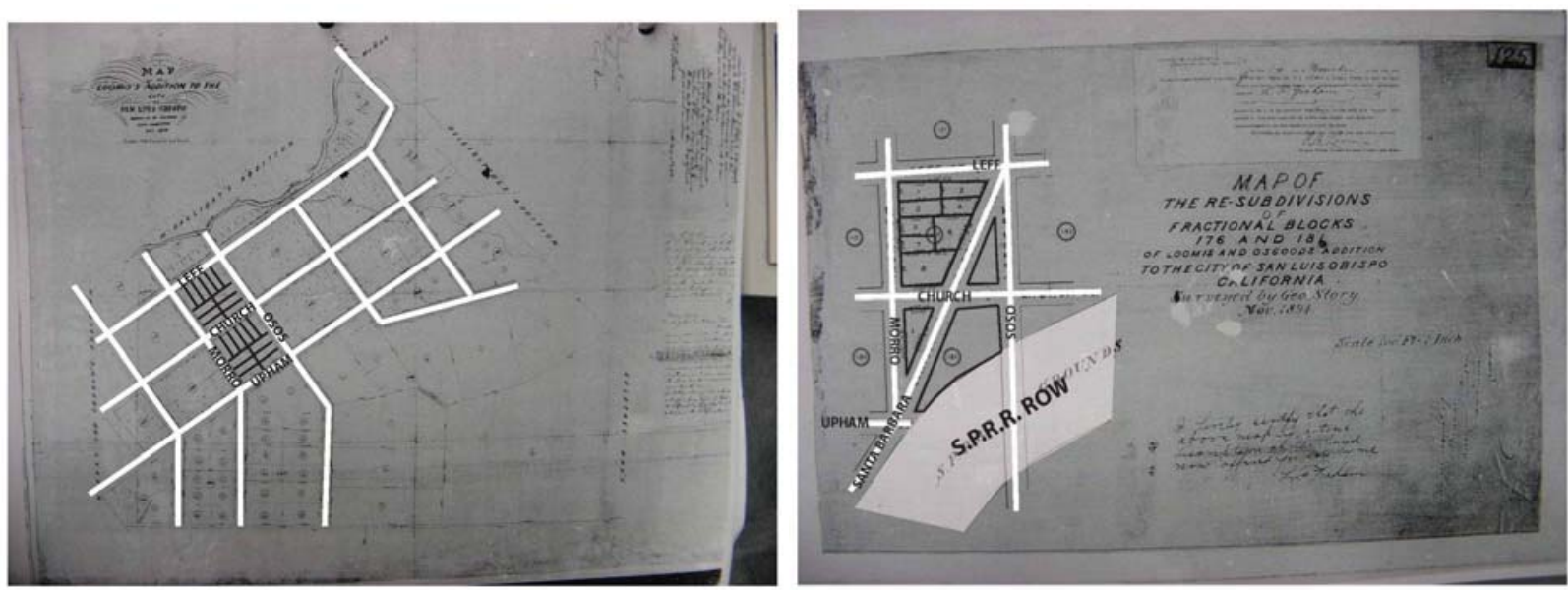

Figures 3.9 and 3.10: The Loomis Tract (1887) and the Loomis and Osgood Re-subdivision (1894)

Graphic: Adrianna Jordan; basemaps courtesy of the City of San Luis Obispo

The railroads' influence on the urban form of the city was pervasive and shaped almost every land use decision around the turn of the $20^{\text {th }}$ century. The next chapter explores the railroads' influence in more detail, delving into its effect on tourism and local infrastructure improvements such as the creation of a public transportation system, sewer system, and street lights. In addition, the next chapter's discussion also covers the local commercial industries that were reliant on the railroad to ship their products both nationally and abroad. 


\section{Chapter 4: Historic Tourism, Economic Development, and the Railroad}

Chapter 3 deals with the mark that the railroads' heyday left on the landscape of the city and how the railroads not only influenced the expansion of the city, but also land use and social stratification within the city. This chapter provides more specific examples of how the railroad influenced economic development such as the development of the Ramona Hotel and the Andrews Hotel which turned San Luis Obispo into a vacation destination. In addition, this chapter illustrates how the railroad facilitated the shifting of the locus of the county's economic activity from the town of Cambria to the City of San Luis Obispo.

\subsection{The Southern Pacific and Tourism}

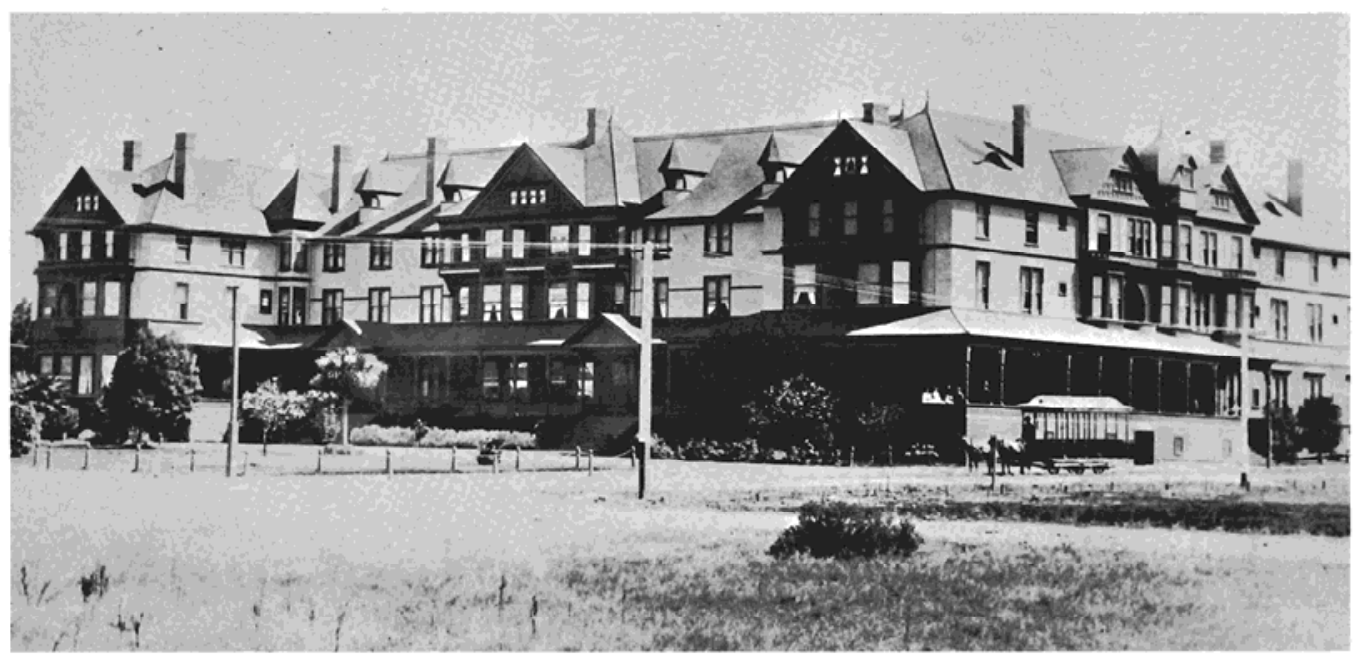

Figure 4.1: The Ramona Hotel with convenient horsecar to the railway station Photo Courtesy of Best (1964). 


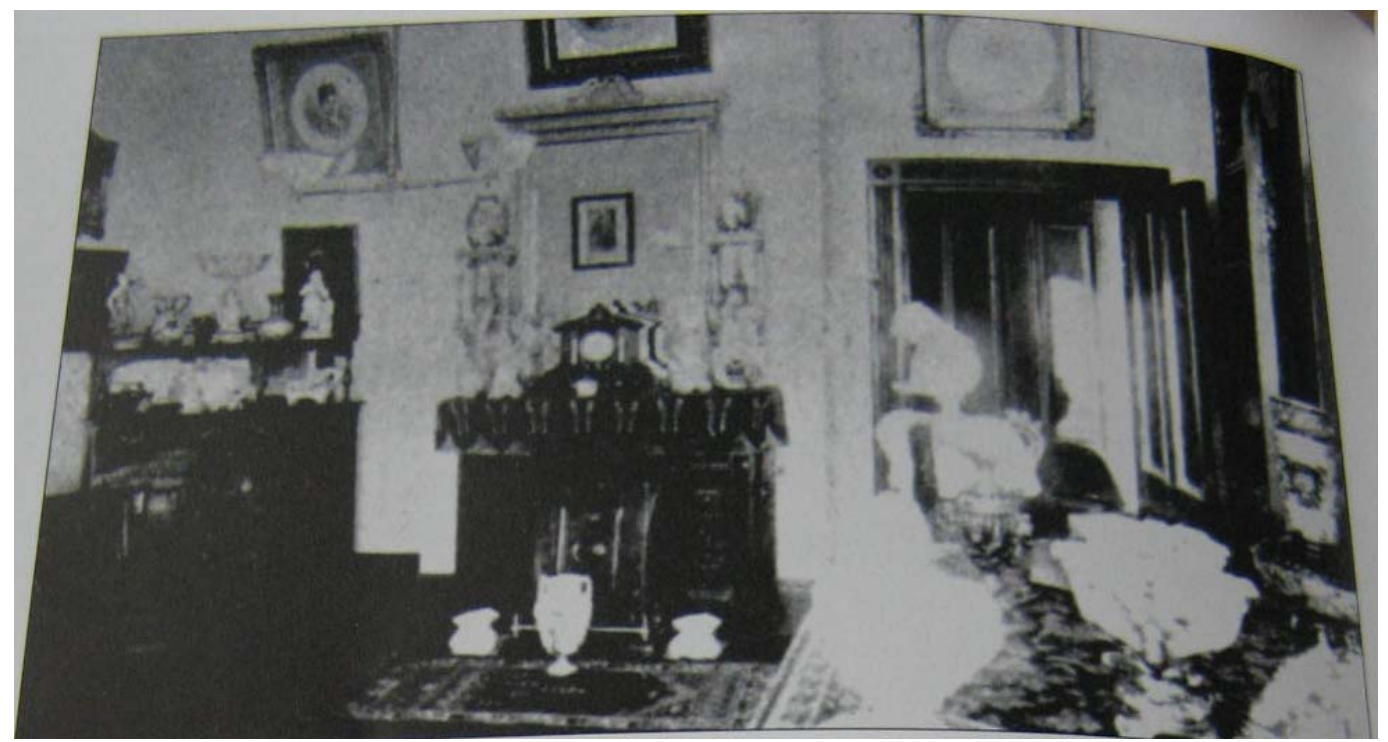

Figure 4.2: The interior of a suite at the Ramona Hotel Photo Courtesy of Franks (2004).

The arrival of the railroad created an instant tourism industry in the City of San Luis Obispo. The full-service Ramona Hotel and the Central Addition subdivision in which it was located were speculative developments based solely on the Southern Pacific's arrival. In fact, on the day that the Southern Pacific finally arrived in San Luis Obispo, a massive celebration was held at the hotel and included “a giant barbeque serving \$330 worth of meat and food” (Krieger, 1989). The 200-room Ramona Hotel (Figure 4.1) was located close to the Southern Pacific tracks on a city block bounded by Higuera, Johnson, Marsh, and Essex (present-day Pepper Street).

The hotel was built with all the best modern amenities such as electric lights, hot and cold running water, and a call system that could summon hotel staff to guest's suites at the touch of the button (Figure 4.2). The better appointed rooms even had dumbwaiters. Its construction and development was a speculative investment so based on the advent of the railroad that the hotel constructed its own Southern Pacific Train Depot (Figures 4.3 and 4.4). This depot is now 
preserved and available for viewing at the Dallidet Adobe Gardens in the City of San Luis Obispo $^{1}$. The Historical Marker at the depot provides some insight on the relationship of the railroad and tourism, noting as follows:

In March of 1896, the Southern Pacific Railroad officially declared that the Ramona Hotel will be an eating station for passengers heading north and south. "It is expected that within a few days tickets can be purchased from the Ramona station and baggage checked from the same point. The station building has been completed several days...so that the station may present an attractive appearance to strangers." San Luis Obispo Morning Tribune 1896). Trains which did not include a dining car stopped to allow passengers a meal at the Ramona Hotel. A street railway running on Marsh Street to the rear of the hotel connected the street car line to the new depot” (The Historic Marker Database, 2011).

The street car was horse drawn and designed to allow the horses to be hitched to either end, eliminating the need for a turn-around at either end of the route.

\footnotetext{
${ }^{1}$ The Ramona Depot was all that remained after the 1905 fire that destroyed the Ramona Hotel. It was donated to the Dallidet Gardens by Life Members of the San Luis Obispo County Historical Society Robert and Elizabeth Leitcher. See The Historical Marker Database, http://www.hmdb.org/marker.asp?marker=38457
} 


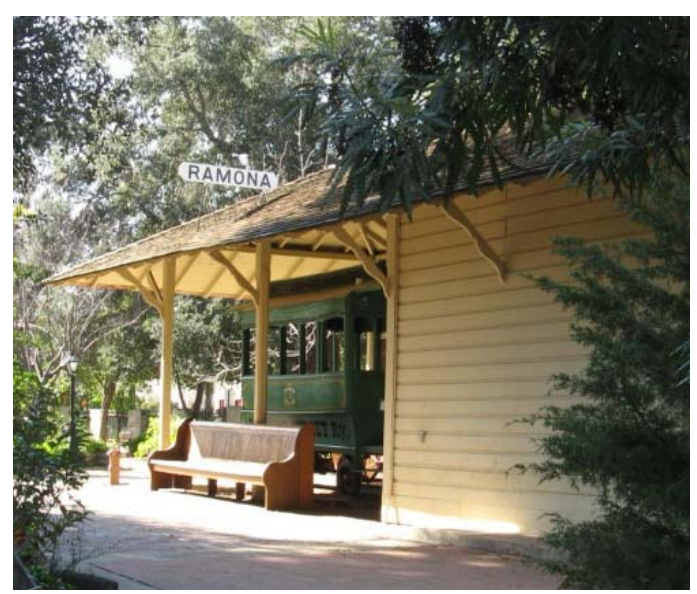

Figure 4.3: Current photograph of the Ramona Hotel Depot on the Dallidet Adobe Grounds

Photo: Adrianna Jordan.

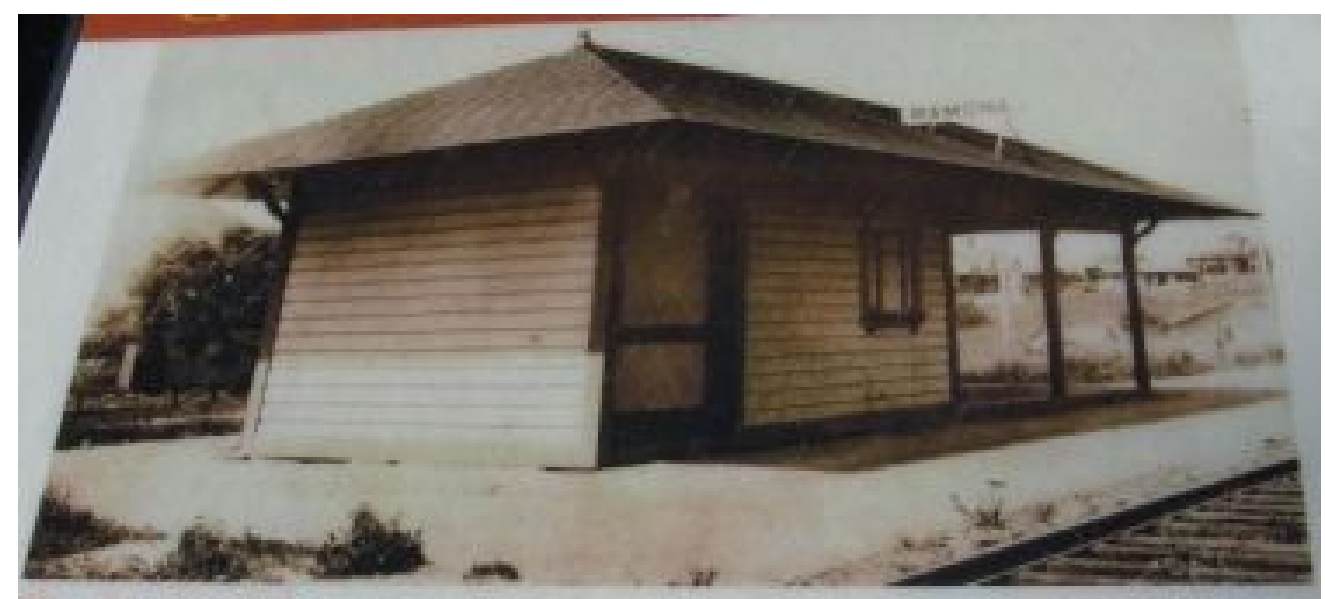

Figure 4.4: Ramona Hotel Depot in original location adjacent to the Southern Pacific tracks

Photo Courtesy of Franks (2004).

In direct competition with the Ramona Hotel, the 112-room Andrews Hotel (Figure 4.5) was

built nearby at the corner of Monterey and Osos Streets. Constructed in 1886, it was designed to cater to upscale travelers and featured 26 suites, 86 single rooms, and 16 bathrooms. Much like the Ramona, it had state-of-the-art amenities such as electric lights, hot and cold running water, and "a system of electric bells connected between the hotel office and all 144 rooms, as a 
safeguard against both fire and burglary” (Nicholson, 1980). Tragically, despite its modern safeguards, the hotel was destroyed twice by fire. The first time it burned down seven months after it opened. The re-built hotel was destroyed in 1905.

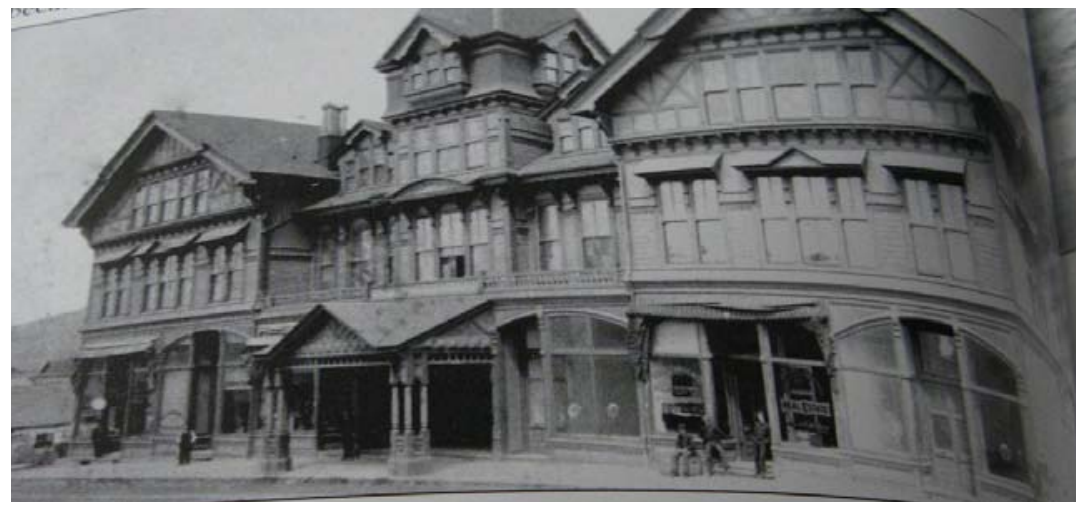

\section{Figure 4.5: The original Andrews Hotel Photo Courtesy of Franks (2004).}

Around the time that the grand tourist hotels were opening, the first Southern Pacific Passenger Rail Depot was built in the mid-1890s between Santa Rosa and Osos Streets. Tourists who disembarked at the station were greeted by uniformed porters. The original depot remained in service until the new depot was built in the 1940s, and was eventually demolished in the early 1970s.

In 1943, a new passenger depot was built for the Southern Pacific at 1011 Railroad Avenue. Standing just north of the old depot the new depot was a Mission Revival style building. The 157-by-33 foot stuccoed building had a broadly pitched red-tile roof, brick chimney, and a two-story central section with tall, arched windows. Thick wooden columns supported the walkway overhangs and square tile details adorned the base of the roofline. A 1942 Telegram-Tribune article reported that "the new station will have stucco interior 
walls, tile floors, decorative ceiling timber trusses, and retiring rooms will be modern in appointments and all public facilities will be of generous proportions” (Franks, 2004).

\section{$\underline{4.2}$ Traders and Businesses}

Before the railroad came to San Luis Obispo, the town, although a cultural and religious hub, consisted of little more than the mission with dusty ranches surrounding it. Until 1870, the center of Central Coast economic activity was actually 40 miles north in the town of Cambria, known as "Slabtown" due to the use of rough-hewn wood slabs in building construction. In the mid 1800s Cambria’s shipping industry was larger than the City of San Luis Obispo’s, and Cambria’s economy was driven by the exporting of cinnabar, lumber, grains, and cattle products. A few miles north of Cambria, San Simeon was also in the shipping business thanks to George Hearst:

In 1878 Hearst constructed a 1,000-foot wharf with a narrow-gauge, horse-drawn railroad to facilitate the loading and unloading of the coastal packet steamers. During the wharf's first year of operation it shipped butter, tallow, beef hides, wheat, barley, oats, dried seaweed, and abalone from the Chinese harvesters along the remote coast, and 169 flasks of mercury from the cinnabar mining operations in the Santa Lucias. Mercury prices were down so this was well below the production and shipping figures for 1866 through 1876 (Krieger, 1989).

Faced with cutthroat ocean shipping competition to the north, it was a life or death situation for the City of San Luis Obispo's burgeoning economy to attract the railroad so that they could capture the advantage of an overland shipping route. At the time, the Southern Pacific was considering running their route along the coast through Morro Bay and by-passing San Luis Obispo altogether. 
In order to convince the railroad to build the tracks through the city, local businessmen cut strategic deals with men from the San Francisco Bay Area such as Charles Crocker. Crocker was a land developer and a member of the "Big four", a group of businessmen who were closely involved with the building of the Southern Pacific. By 1886 "Crocker had already begun a game of hardball with the business community in the county seat of San Luis Obispo. The railroad was scheduled to turn west toward Morro Bay, following the route later taken by State Highway 41 . References had appeared in the San Luis Obispo Tribune suggesting that 'Crocker, being the last town before ascending the grade to Morro Bay, will very likely have machine shops and workshops of the Southern Pacific Railroad'” (Krieger, 1989). At the time, Crocker had named one of his real-estate investments (now known as Templeton) after himself. The name was later changed to the name of Crocker's son because of the unpopularity of Crocker within the local community due to his railroad and land dealings.

Despite Crocker's influence, and due in large part to extensive lobbying by Tribune Editor Myron Angel, the executives of the Southern Pacific eventually did decide to route the railroad through San Luis Obispo via Santa Margarita and the Cuesta Grade. Also playing a role in this decision were the various economic incentives such as free land for the rail right-of-way and infrastructure improvements such as a streetcar line that linked the rail depot to the rest of town. These incentives were provided to the railroad by the business community of the City of San Luis Obispo. 
In 1887, action was taken to create a street car system for public transportation in the city. Concurrently, a petition was filed to install electric street lights. A couple of months later, a Board of Trade was formed to promote immigration and land sales. The promotions undertaken by the board included the creation of literature touting the resources of the county (Figure 4.6), and an exhibition about local resources at a theater. Ironically and perhaps anticipating a symbiotic relationship, even the Pacific Coast Railway was involved with indirectly courting the Southern Pacific by offering to ship materials used for county promotional purposes free of charge. Overall, the board "published 25,000 brochures, sponsored 10,000 or more copies of the San Francisco Journal of Commerce with feature articles about San Luis Obispo, paid for 36,000 copies of the Tribune, distributed 25,000 copies of a thirty-eight page booklet, and sent an exhibition of products to various fairs" (Nicholson, 1980). 


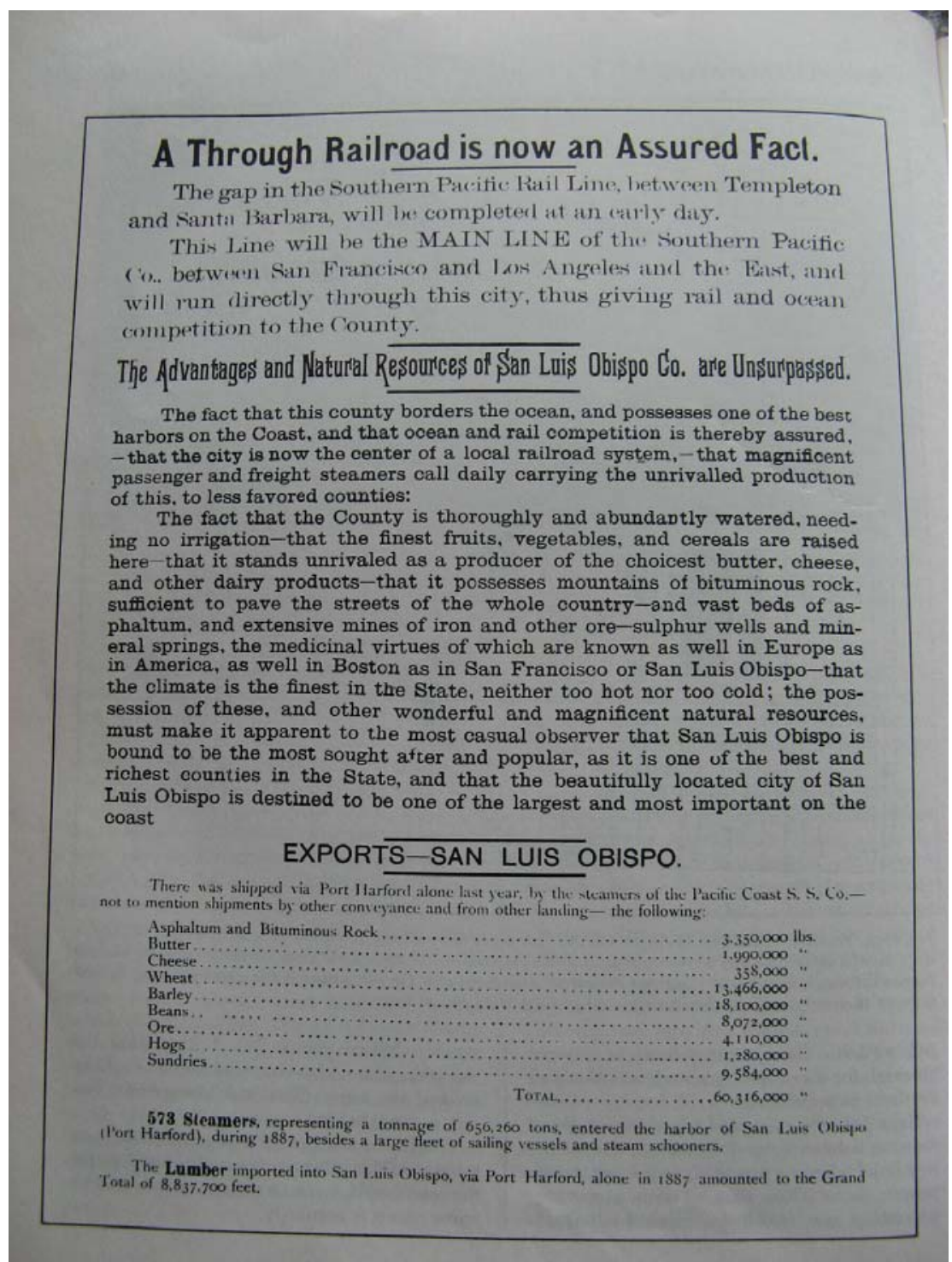

\section{Figure 4.6: An 1887 advertisement about local economic resources Figure Courtesy of Nicholson (1980).}

Unfortunately, despite all of the lobbying efforts, after the Southern Pacific railroad reached

Santa Margarita in 1889, it remained stuck there for six years because of economic uncertainty.

"The Panic of 1893 had frozen investment capital, and the Southern California land boom of the

1880s had resulted in a great deal of over-speculation” (Krieger, 1989). Railroad investors and

their capital all but disappeared until the economy improved in the mid 1890s and the railroad

finally reached the City of San Luis Obispo. 


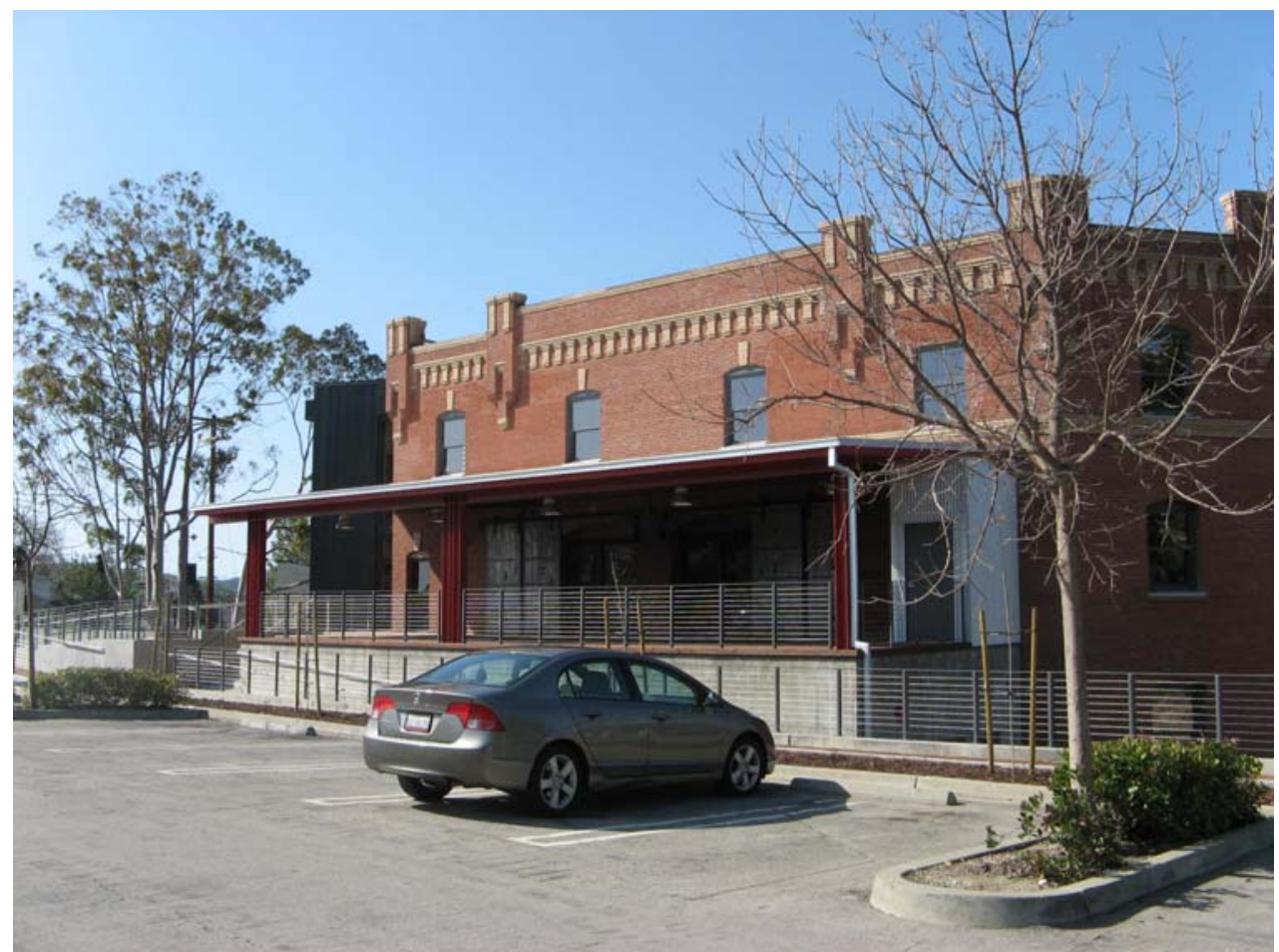

Figure 4.7: The back of the Channel Commercial building as it looks today Photo: Adrianna Jordan.

Evidence of San Luis Obispo's growing economic power could be found in sheer number of warehouses and lumber yards that filled the east side of Higuera Street between Beebee and High Streets. One facility of note was located in what's currently known as the Railroad Square Building (Figure 4.7). Starting in 1912, this building was occupied by the Channel Commercial Company which specialized in refrigerating most of the groceries that were imported to San Luis Obispo. "Beginning in the 1840s, refrigerated cars were used to transport milk and butter. By 1860, refrigerated transport was limited to mostly seafood and dairy products” (Krasner-Khait, 2003.) A spur track ran directly behind the building to facilitate convenient off-loading. This business remained in operation until the advent of refrigerated trucks around 1950. Another business, a brickyard, remained in operation from 1921 to 1980 when it was shut down for Air Pollution violations. 
In addition to providing a means for private businesses to conduct trade beyond the local area, the railroads also created a multitude of jobs for local citizens since both the Pacific Coast and the Southern Pacific railroads located their division headquarters and maintenance yards in San Luis Obispo. Possible railroad occupations included agents, brakemen, car inspectors, clerks, conductors, engineers, firemen, machinists, foremen, managers, switchmen, telegraph operators, and yardmen. Regardless of whether the job was working class or middle class, it was steady employment and helped raised the standard of living for the community, as well as increase local buying power.

The railroad's presence in the City of San Luis Obispo also had a positive effect on the neighboring communities of Arroyo Grande and Santa Maria. The cheap form of goods movement fueled agricultural and commercial development and shipped millions of tons of grains, beans, pears, and dairy products off to previously inaccessible markets.

During World War I, the strategic location of the County of San Luis Obispo's agricultural land in proximity to the Southern Pacific route helped drive the local economy at a time when the overall worldwide economy was faltering. Prices for agricultural commodities soared in the face of European shortages and local farmers were able to reap high profit margins on goods such as grains and beans. In particular, dried navy beans became a sought-after commodity for the U.S. Military during the war and Central Coast farmers grew millions of beans for export. Due to this: Virtually all of the Pacific Coast Railway warehouses added bean-cleaning towers. These devices sifted off dirt and stones from the picked beans through a series of sieves. The price of cleaned navy beans, which was subsidized under war emergency measures, rose 
from $11 \frac{1}{2}$ cents to nearly 30 cents a pound. Previously untilled pastureland [sic] was quickly turned to bean production [...] The war left many farmers unbelievably rich. However, many of them lost their newfound wealth when the government abruptly cut off the magnificently high subsidized prices in December 1918. (Krieger, 1989).” Although the Southern Pacific was the favored railroad for most goods and passengers, The Pacific Coast Railway continued to maintain a niche client base and non-perishable items that did not require speedy transport such as beans, some types of produce, and seed continued to be primarily shipped via the Pacific Coast Railway and steamers until after World War I. Therefore, most of the navy beans grown by local farmers were shipped around the world via Port Harford. Given impending food shortages worldwide, the Central Coast's continued agriculturally-driven economy could secure the region's self-sufficiency well into the future.

This chapter shows how the tourism industry got started with significant help from the city's location along the Southern Pacific railroad tracks. In addition, it provides a detailed overview of how the city's economic fortunes benefitted from the presence of the railroads. The next chapter covers lesser known aspects of the local economy such as the Chinese contribution to the railroads, road building, and many other jobs that were deemed "undesirable" by the majority of the population due to their back-breaking nature and low pay. 


\section{Chapter 5: Chinatown and the Chinese Contribution to the Railroad}

The importance of the Chinese contribution to the region's roads, railroads, and other public works projects cannot be overstated as they kept the local economic engines churning due to their reliability and willingness to work for lower wages than their American counterparts.

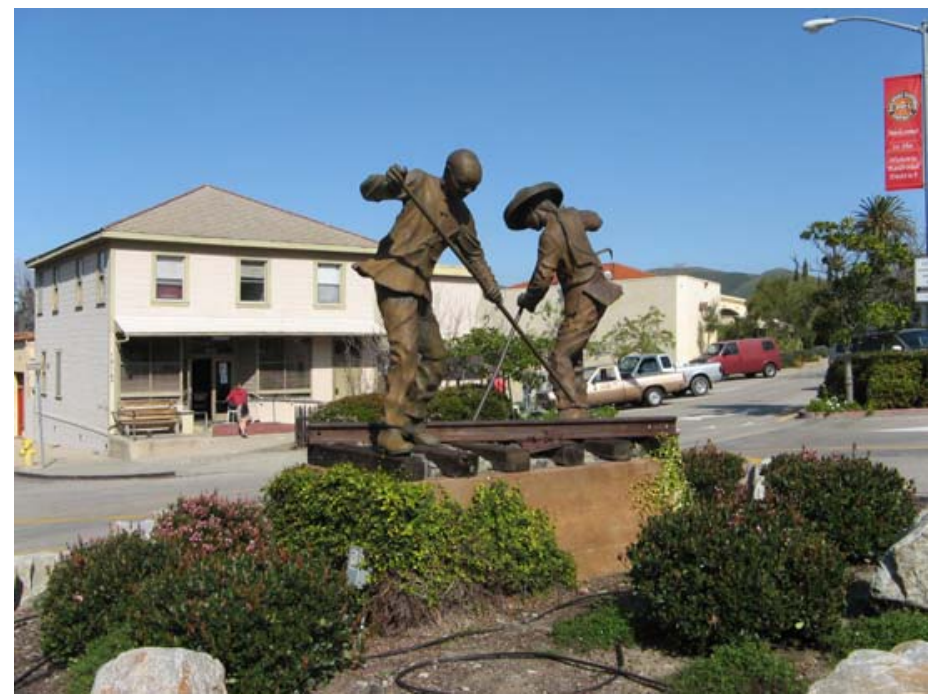

Figure 5.1: Iron Road Pioneers (2003)

Photo: Adrianna Jordan.

Chinatown, roughly considered the area between Chorro, Mill, Morro, and Monterey streets, flourished in the City of San Luis Obispo after Chinese immigrants came over to California to work on the various rail projects. Although most people knew the neighborhood as "Chinatown", the actual residents who lived there referred to it as Tong Yun Fow, or "Chinese People’s City" (Heritage Shared, 1998). Most Chinese were employed as contract laborers and took on the heaviest and toughest work related to building the rail lines; in return, they were typically paid one dollar a day plus board. In fact, the reason that the Chinese were able to find rail related jobs was because the work was so back-breaking and so poorly paid that there were not enough 
Americans willing to do it; therefore, much like the agricultural industry relies on Mexicans for labor today, it was necessary for the railroads to import their workforce. The Iron Road Pioneers sculpture located in the historic San Luis Obispo Railroad District pays homage to the Chinese contribution to the construction of the railroads (Figure 5.1).

“Between 1870 and 1900, Chinatown’s population varied from two to four hundred, peaking in the early1890s, when one out of every ten residents of San Luis Obispo was Chinese” (Heritage Shared, 1998). The undisputed leaders of the Chinese community were Wong On (Ah Louis) and Gin Sai Yuen (Quong Chung). Ah Louis “came to the county in 1869 and worked as a cook for the French Hotel. Within the next few years, on the advice of Captain John Harford, he began working as a labor contractor” (Krieger, 1989) for the narrow-gauge rail being built between San Luis Obispo, Avila, and Los Alamos. According to local legend, Ah Louis also got his moniker from Harford because it was easier to pronounce than his given name. "Ah” is a kind of Chinese nickname or greeting used in place of the full name for a friend or family member, and "Louis" originally started off as "Luis". Harford was a kind of friend of Ah Louis so he would affectionately refer to him as “Ah Luis”, which is sort of like jokingly saying “Mister San Luis Obispo". However, contrary to local legend, according to an interview given by Ah Louis in 1934 to Chester Newton Hess, Ah Louis is quoted as saying, “Ah Louis not my real name. Ah Louis name given me by John Morgan, owner of general merchandise store in Corvallis, Oregon” (Hess, 1934).

Ah Louis also ran a merchandise store that catered to the local Chinese population and doubled as a kind of recruitment office for railroad laborers. Although it started out in a different 
building, Ah Louis built a larger two-storey stuccoed structure with an iron rail balcony for the store in 1885:

"The main room on the lower floor was designed and furnished with shelving, drawers, counters, etc. for a store, another good-sized room for storage of goods, another for a private room and office and a hallway across the building in the rear. The upstairs is divided into six rooms for sleeping apartments. The partitions are of alternate strips of dark and light redwood, oiled, and varnished, giving a very pleasant effect” (Nicholson, 1980).

The building was added to the National Register of Historic Places on March $26^{\text {th }}$, 2008. Other stores in Chinatown included the Mee Heng Low chop suey shop (Figure 5.2), the Shanghai Low, Chong’s Hand Made Candies building (Figure 5.3), gambling dens, laundries, and various tenements (Figures 5.4 and 5.5). 


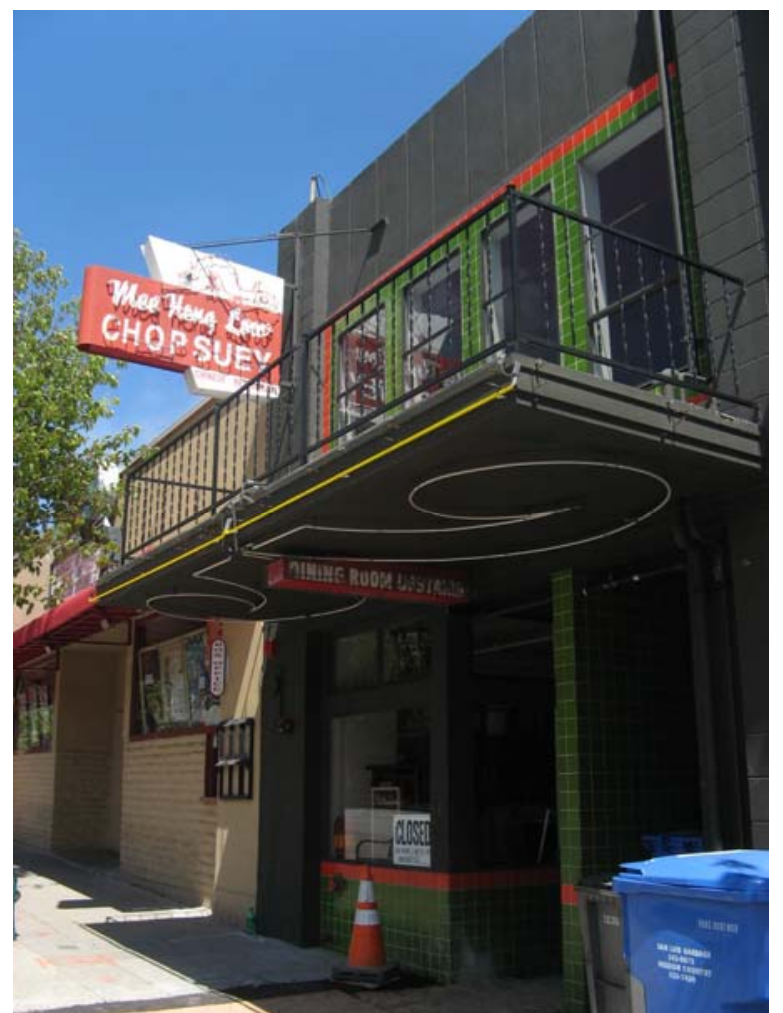

Figure 5.2: Mee Heng Low Chop Suey Shop Photo: Adrianna Jordan

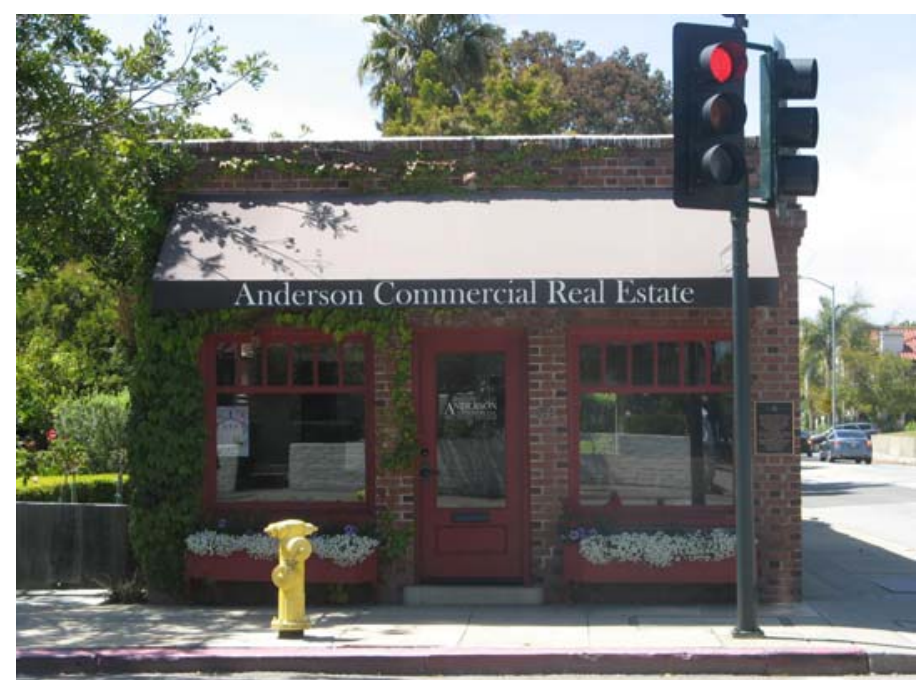

Figure 5.3: Chong's Hand Made Candies Photo: Adrianna Jordan 


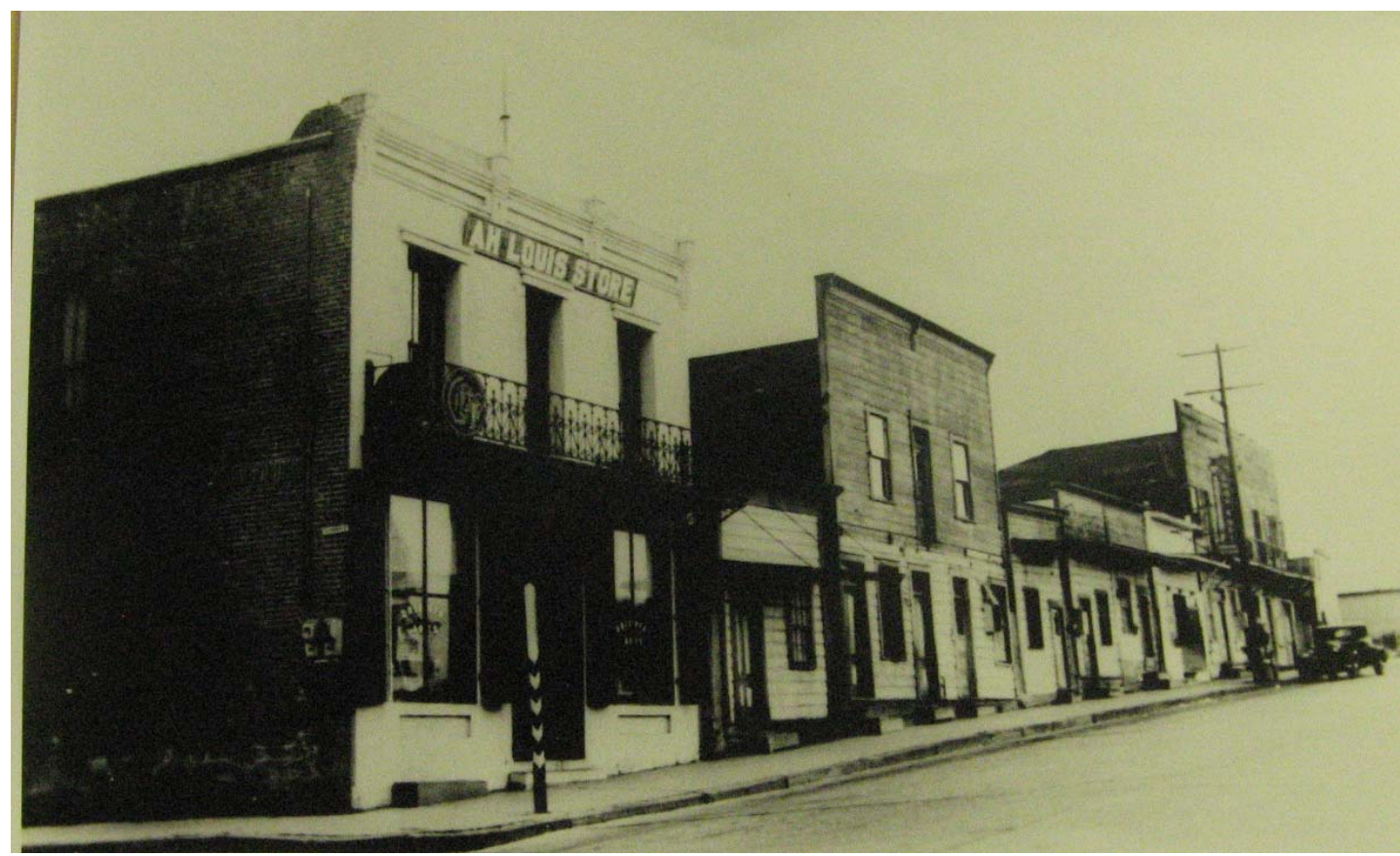

Figure 5.4: Looking east down Palm Street in turn of the century Chinatown. Photo Courtesy San Luis Obispo History Center.

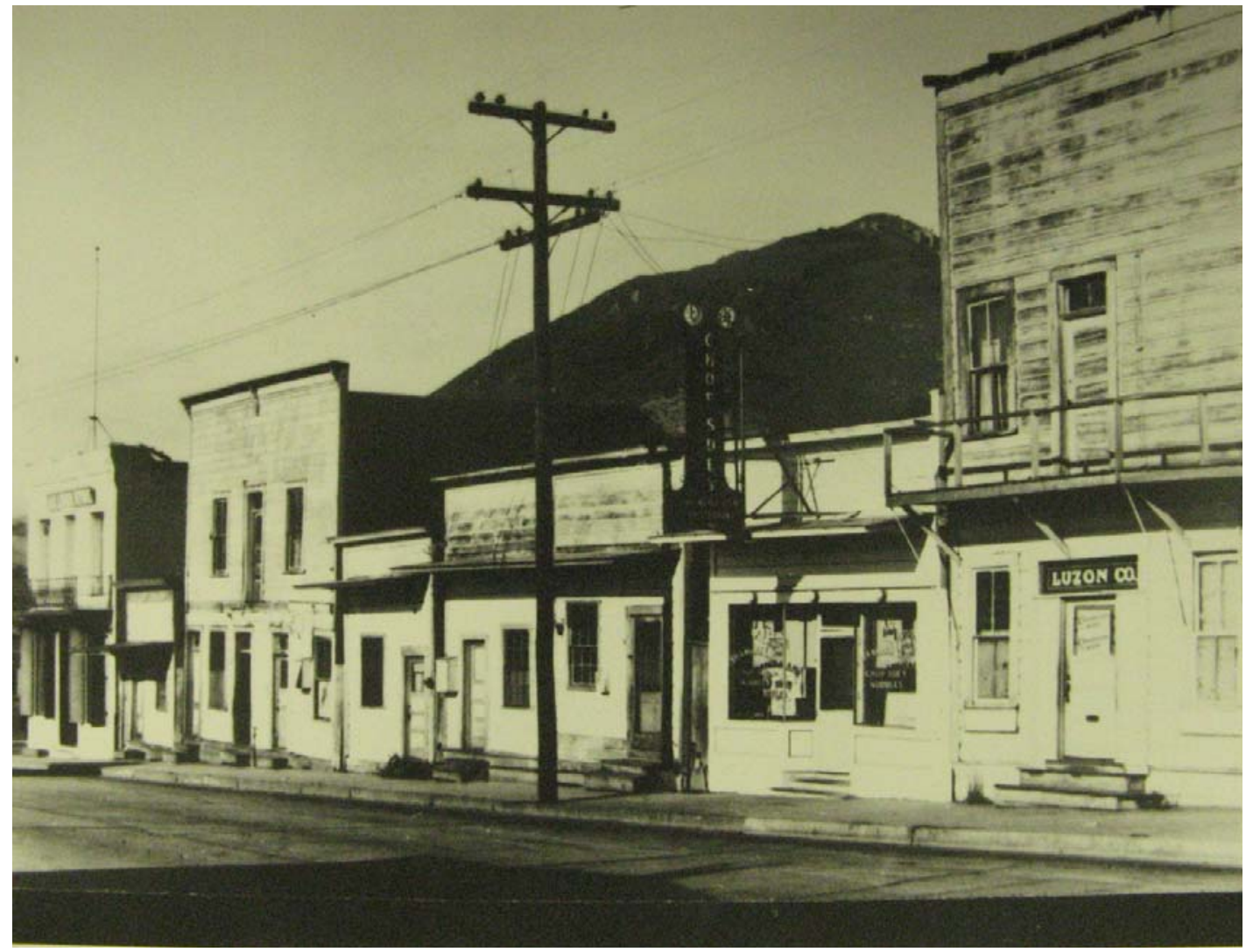

Figure 5.5: Looking west down Palm Street in turn of the century Chinatown. Photo Courtesy San Luis Obispo History Center.

Page 60 
Using money he earned as a contractor, Ah Louis bred large work horses, bought fast race horses, and "later started the first brickyard in the county and was involved in the early seed industry. A well-respected member of the community, he died in 1936 at the age of 98” (Krieger, 1989); however, his legacy lives on in his direct descendents who continue to play a prominent role in the community and still own the store (Figure 5.4). In fact, his youngest son, Howard Louis continued to operate the store until the 1990s, and recently passed away in 2008 at the age of 100. Currently, the building is owned by Ah Louis' great-grandson Dr. William Watson.

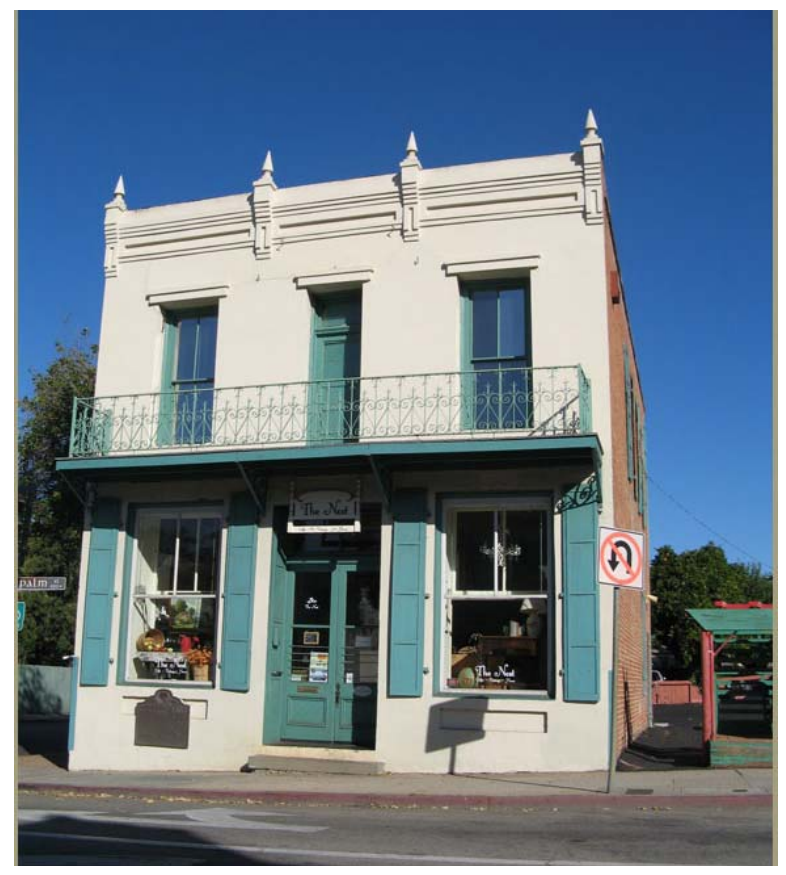

\section{Figure 5.6: The Ah Louis Store as it looks today. Courtesy of Heritage Shared (2011).}

Although the Chinese were primarily responsible for the construction of the Pacific Coast Railway, according to research conducted by local historian Loren Nicholson, they were used only sparingly to build the Southern Pacific line in San Luis Obispo County: 
In May 1886, the Tribune reported “1,500 Chinese coolies” were at work laying track south of Soledad. After the line reached Templeton, a long delay in construction occurred, but in October 1888, work started again, and the Tribune announced that "150 Chinamen, 100 white laborers, and 50 bridge carpenters” were at work. The next month, November 1888, the newspaper again reported "long lines of Chinamen” stretched along the ravine, "their shovels flying in the air with monotonous regularity" (Nicholson, 1980).

By the end of 1888, work had again stopped on the railroad, and Chinese immigrants had to find other ways to make a living. Other types of jobs available to them included mining for cinnabar in Cambria, harvesting seaweed and abalone along the Central Coast, laundering clothing, cooking in restaurant and hotel kitchens, building county roads, and laboring in the agricultural fields of San Miguel and Guadalupe.

Despite the earlier Chinese involvement, when the railroad again started up construction in the early 1890s, the Chinese were no longer employed by the Southern Pacific. According to Nicholson, by 1893 Southern Pacific’s Chief Engineer William Hood was concerned "about the labor problems the company had been experiencing along the gap. 'There are now from 1,000 to 1,200 men down there at work,' Hood was quoted as saying, 'but there are changes all the time, and we have to keep sending down new gangs. Not a Chinaman has yet been employed - except as a cook - but the work has to be done, and we may have yet to employ Chinese laborers'” (Nicholson, 1980). Despite Hood's claim that no Chinese were working on building the rail line over the Cuesta Grade, local historian Dan Krieger disagrees and believes that 2,000 Chinese 
workers dug seven tunnels through Cuesta Grade for the Southern Pacific segment located between Santa Margarita and San Luis Obispo.

Around 1894, a new federal law was passed that required the Chinese to obtain certificates of residency until penalty of deportation. Ah Louis quickly took on the responsibility for ensuring that all of his countrymen were properly registered within the appropriate time period. This new registration law operated as a supplement to the already draconian Chinese Exclusion Act of 1882 which allowed the U.S. to ban Chinese immigration. It was meant to stay in effect for approximately 10 years but did not actually get repealed until the Magnuson Act of 1943.

Between jobs, the Chinese community used the City of San Luis Obispo as a home base. Despite the fact that they were a substantial portion of the community, no Chinese are present in the 1904 telephone directory. Speculating on this, the reason no Chinese were in the directory could very well be because they typically lived in shared tenements with communal public telephones, or by 1904 they may have already moved on since the building of the railroad tracks in the area was complete.

By 1950, due to prohibitions on new immigration, an aging immigrant community, and the aftereffects of the Great Depression, the Chinese population of the City of San Luis Obispo had dwindled to only 50 individuals.

The Chinese were just one of many population groups associated with the railroads, and the next chapter unfurls the complicated relationship between farmers and the railroad in the late $19^{\text {th }}$ 
century. In addition, the chapter delves into detail on how the expanded freight movement offered by the railroads permanently changed the way buildings were constructed in the city. 


\section{Chapter 6: Shifting Nature of the Relationship between the City and the Railroad}

Most of the farmers in the area had a complicated relationship with the railroad in the late $19^{\text {th }}$ century. Although they depended on the railroads for their livelihood, farmers, much like the Chinese in the previous chapter, were exploited by the rail business. This chapter examines how the farmers were exploited by the railroads and what the farmers did about it in response.

Additionally, this chapter also discusses the way that the railroads influenced architectural styles in the city.

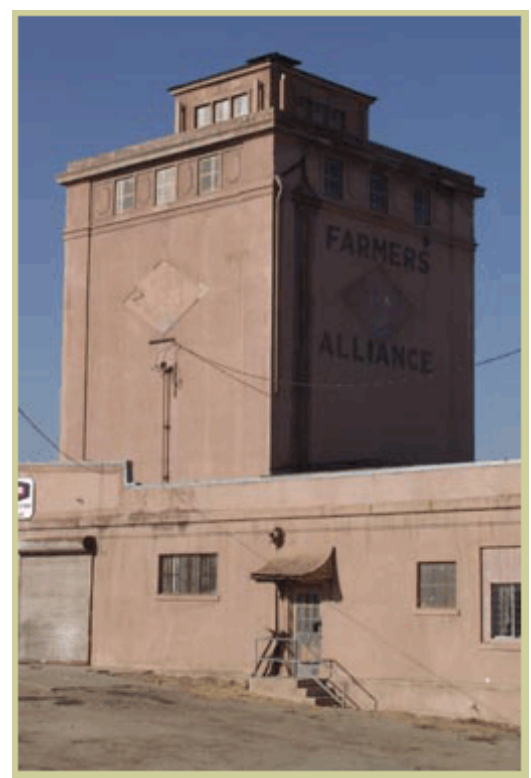

Figure 6.1: Farmers Alliance Building in Paso Robles. Courtesy of Heritage Shared (2011).

\subsection{Farmers and the Railroad}

In the late $19^{\text {th }}$ century the railroad was the primary means of marketing and transporting crops from farms to markets and therefore farmers were completely dependent on the railroad. In addition, farmers' profits also depended on the amount charged by the railroad for transportation, 
storage, milling, and marketing. The railroads were keenly aware of the farmers' position and kept their fees so high that often farmers had trouble paying their mortgage - even when crop yields were good. In response to the inherent inequality between the railroad and the farmers, the Farmers Alliance group was formed by U.S. farmers to strengthen their economic power.

The Farmers Alliance was strongly associated with the People's Party. One of the platforms of the People’s Party was that “all excess railroad and corporate lands would be reclaimed by the government and held for actual settlers”. This platform was important because the first Transcontinental Railroad, completed in 1869, was financed in part by a grant of bonds and gifts of public land by the U.S. Government that could, in turn, be sold to the public. "Congress provided land grants consisting of ten alternating square miles of land on either side of its proposed right-of-way to the transcontinental railroads as incentives for each mile of track actually laid... The long-awaited release of this land for private ownership created a land boom in northern and eastern San Luis Obispo County.” (San Luis Obispo County History Center, 2010). Often, the railroads engaged in a form of price gouging, setting the price per acre at one level, waiting for settlers to make improvements on said land before the land deed was formally exchanged, and then turning around and trying to sell it to the settler for ten times the original stated price. Due to the fact that many of the prospective land owners were farmers, this further entrenched the position of the Farmers’ Alliance.

The Farmers' Alliance organization reached its apex in the 1880s and then declined in response to retaliation from the railroads and commodities brokers. The historic Farmers Alliance building (Figure 6.1) in Paso Robles "may be the last building in the United States still bearing the words 
Farmers Alliance” (Retrieved from: http://www.heritageshared.org/docs/livinglandtour1.html, 2011).

\subsection{San Luis Obispo City Form}

The previous section described how the railroads were able to directly influence local land use. This next section shows how the railroads indirectly influenced land use, urban design, and architecture. In particular, the arrival of the railroads also meant the arrival of new building materials that would forever change the architectural character of the city.

Three major factors influenced the city's form throughout its history. Initially, the mission was the first factor and created a focal point for the town. In turn, the town grew up around the mission according to a centralized Spanish grid. During this period, the primary mode of travel around the town was walking.

The second factor was the introduction of the railroad to the City of San Luis Obispo community. The railroad shifted new residential development in the city to the east along the railroad right-of-way and also to the north and south in a linear pattern along the tracks. Around this time, the city decided to provide public transportation between the new subdivisions near the railroad tracks and the old Mission core. Following the same linear patterned development, a horse-drawn street car line was secured by Willard Kimbell in 1887 and operated on a fixed route along Monterey, Higuera, and Osos streets. Kimbell’s House at 690 Islay Street was built around 1902 and is still standing. 
The third factor to influence the city's growth was the founding of Cal Poly in the early $20^{\text {th }}$ century. By this time, cars were starting to become commonplace and some of the last subdivisions incorporated by the city are located northeast of the original mission center between Santa Rosa and California Streets adjacent to the Cal Poly campus. Cal Poly's enrollment tripled after the GI Bill and in the first five post-war years the city grew by almost $50 \%$. The housing market could not keep up and a 20\% gap was created between the number of households and the number of dwelling units. Although Cal Poly's recent dormitory construction has helped with the housing shortage, the gap is not closed yet and working families are often left competing with college students for rental housing that can run an average of $\$ 1,500$ per month for a twobedroom house or apartment.

\subsection{Notable Commercial Buildings Related to the Railroad}

The arrival of the railroad from San Francisco in 1894 was welcomed by local architects and builders because it made more exotic construction materials available. This meant that heavier, previously prohibitively expensive or altogether unattainable materials such as cast-iron and steel could now be used to construct commercial and residential buildings in the city. Despite this, most lumber destined for construction uses continued to be shipped via steamship and the Pacific Coast Railway. Prior to this turning point, most structures were constructed of adobe mud brick, stone, and sparing use of locally foraged woods such as pine and oak. Now, merchants could advertise their prosperity by designing decorated cast-iron storefronts such as the Sinsheimer Brothers storefront at 849 Monterey Street (Figure 6.2). "The facade, including its columns, was fabricated at the City Iron Works of San Francisco" and shipped in sections to San Luis Obispo (History in San Luis Obispo County, 2001). 


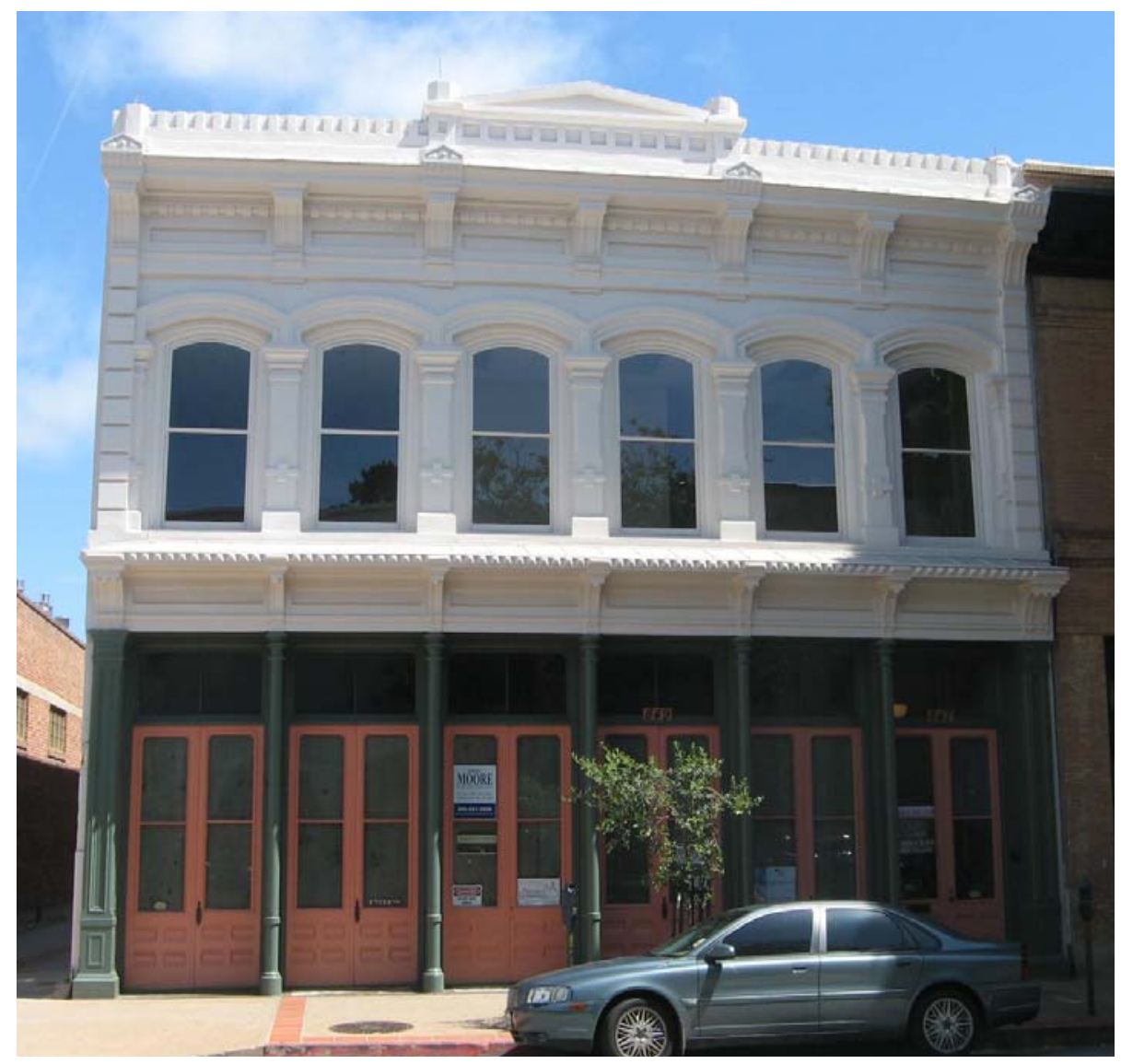

Figure 6.2: Cast-iron Sinsheimer Bros. storefront. Photo: Adrianna Jordan.

A number of notable commercial buildings were constructed in direct response to the Southern Pacific’s arrival in the City of San Luis Obispo. The Call/Parkview Hotel aka “The Establishment”, located at 1703 Santa Barbara Street (Figure 6.3) was built around 1886 and operated as a hotel and boarding house. The Tribune Republic Building, located at 1763 Santa Barbara Street was built in 1873. It is the oldest wooden commercial structure in San Luis Obispo, and has been occupied by a newspaper, hotel annex, rooming house, and residential apartments. The Del Monte Grocery at 1901 Santa Barbara Street (Figure 6.4) was built in 1922 in false-front style. Although it started as a barber shop serving locally living railroad workers, it later became a grocery, and has been operating as a restaurant since 1981. The three-story Glen Page 69 
Dell hotel at 1815 Osos Street (Figure 6.5) was constructed in 1906 for railroad engineer James Reidy and his wife, Dora, and operated as both a boarding house and a hotel. In 1920, it became "the Axtell Hotel, and in 1938, the Hotel Park. By the early 1980s, the structure had fallen into disrepair and was closed. In 1984, the historic hotel received a \$1 million renovation. The upper floors were converted into 21 low-cost apartments, and the ground level into retail space for restaurants and shops” (Franks, 2004). Another railroad era boarding house was the California Renaissance-style Allen House built at the turn of the century at 1443 Osos Street and known as “The Foundation”. Yet another boarding house was the Duff House at 1717 Santa Barbara Street. Built in 1901 in Queen Anne style for the Duff family, it was later sold to the Parson family who converted it into rental apartments for railroad workers until 1956 when it began to primarily cater to college students.

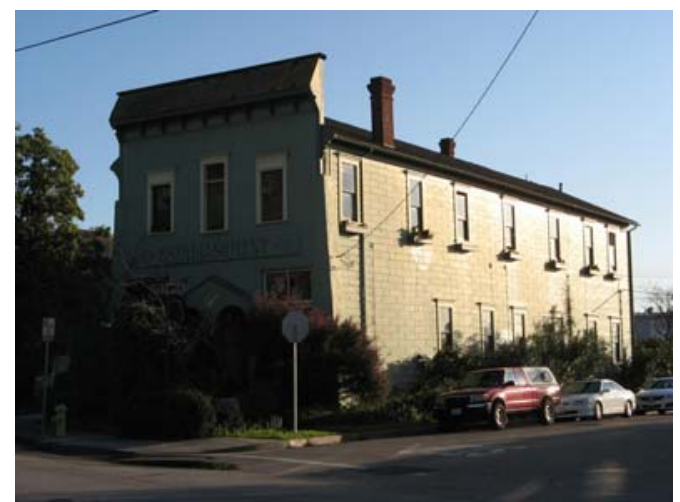

Figure 6.3: The Call/Parkview Hotel at 1703 Santa Barbara Street Photo: Adrianna Jordan. 


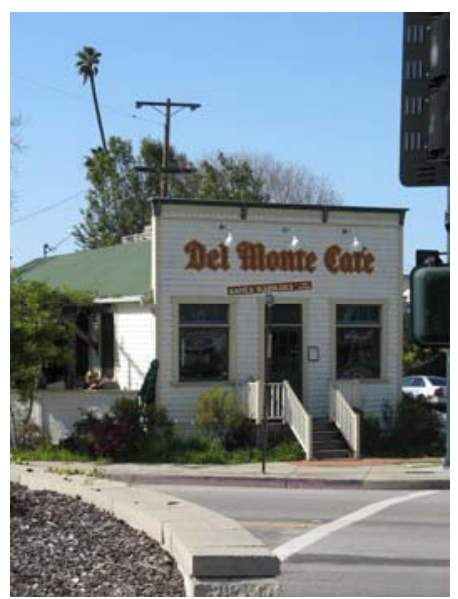

Figure 6.4: The Del Monte Grocery at 1901 Santa Barbara Street Photo: Adrianna Jordan.

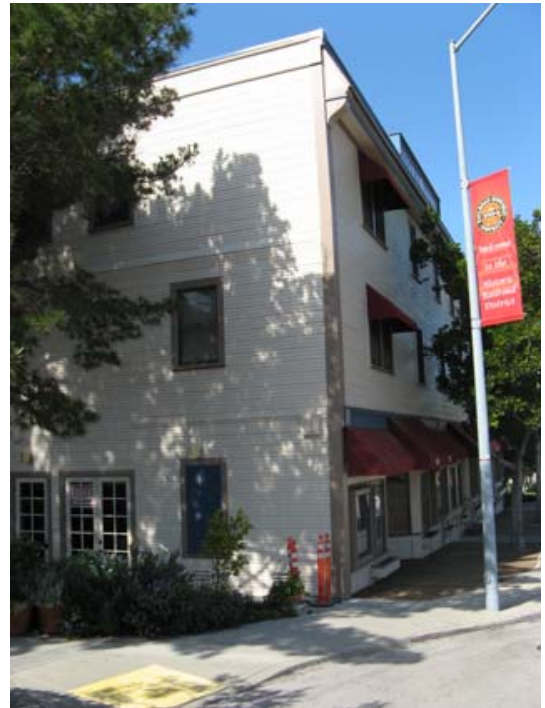

Figure 6.5: Hotel Park / The Glen Dell Hotel Photo: Adrianna Jordan. 


\subsection{Housing}

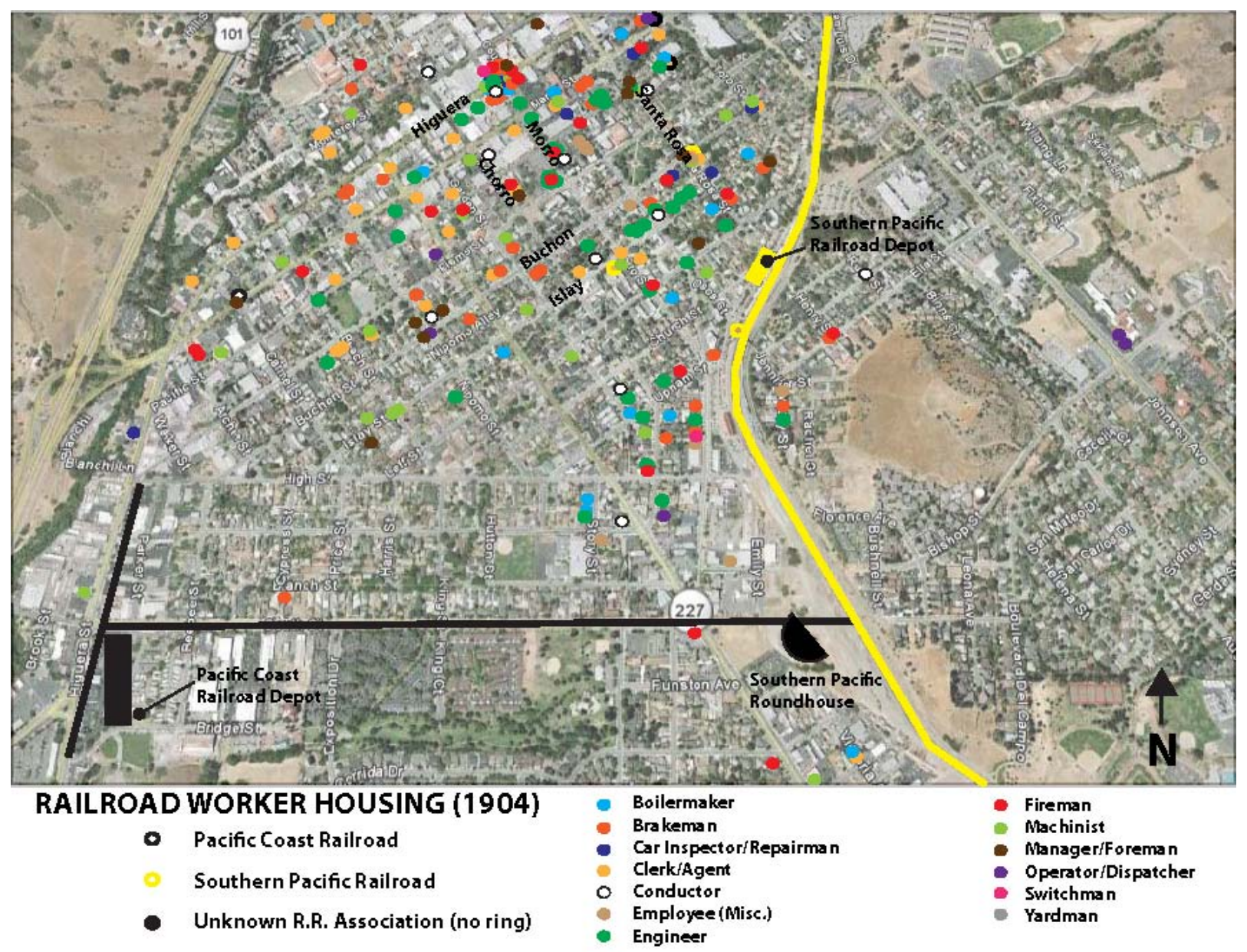

Figure 6.6: Location of railroad worker housing in 1904.

Graphic: Adrianna Jordan.

The advent of the Pacific Coast Railway in the city, and the subsequent arrival and dominance of commerce by the Southern Pacific, impacts the fabric of the city by substantially moving the city's center of gravity away from the Mission core. Telephone directories from the turn of the century provide some clues about this shift. A rough sketch of the locations of railroad worker housing helps delineate shifts in city morphology during the period when the Pacific Coast Railway was dominant, and then after the Southern Pacific's arrival. Figure 6.6 is a map of the 
City of San Luis Obispo illustrating where railroad workers were noted as living according to the 1904 city directory. It reveals that most of the railroad workers still lived in downtown San Luis Obispo with a very high concentration of lower-skilled workers living at the Laughery boarding house located at the corner of Higuera and Morro Streets. The boarders had European surnames such as Carter, Dixon, Hall, Hoogendyk, Kennedy, Lewis, Lynch, McComis, Phillips, and Schaumleffle reflecting who was migrating to this area and finding work on the railroad. Predictably, a cluster of managers and train conductors (included in the "Train Personnel” category) is found on the better location of Buchon Street. This street attracted higher income residents precisely because of its slightly higher elevation and distance away from the soot and grime created by the coal-powered steam engines. In contrast, the map reveals that most of the railroad engineers (also included in the "Train Personnel” category) lived along a two-block stretch of Islay Street between Morro and Santa Rosa Streets.

In contrast to the 1904 map, the 1914 map (Figure 6.7) illustrates a tangible shift in railroad worker housing from the downtown to the eastern edge of town near the tracks of the Southern Pacific Railroad. It also reveals that, by 1914, the vast majority of workers in the city worked for the Southern Pacific Railroad instead of the Pacific Coast Railway. It is also apparent that while the majority of Southern Pacific workers clustered near the tracks and each other, the workers of the Pacific Coast Railway were quite dispersed throughout the west side of the city. 


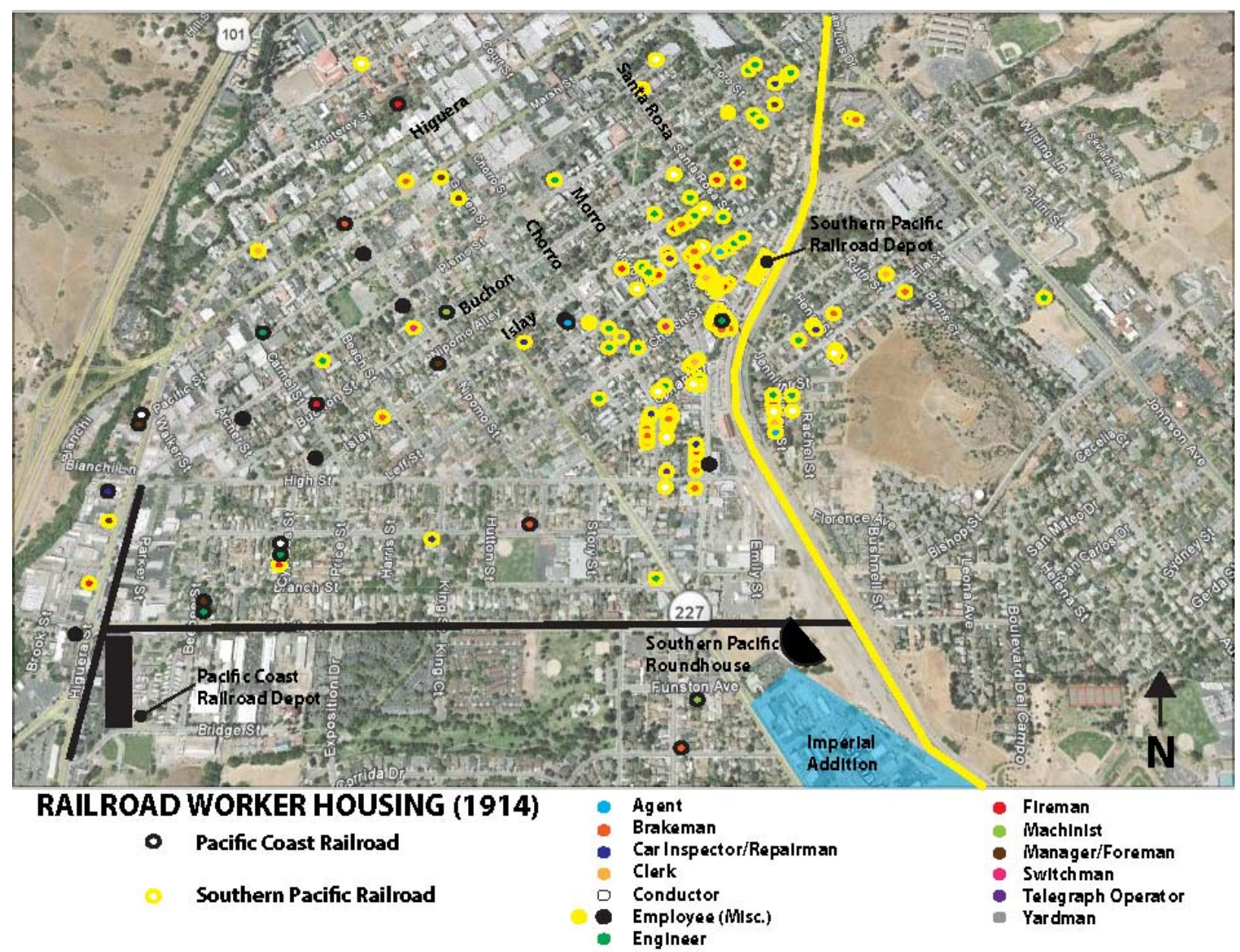

Figure 6.7: Location of railroad worker housing in 1914. Graphic: Adrianna Jordan.

New worker housing for the Southern Pacific railroad shifted the city’s growth towards the southeast of town in new subdivisions such as The Imperial Addition. It was a "Royal Subdivision” first mapped in 1894 and streets took after European and Asian monarchs with names such as Humbart, Victoria, George, Alphonse, Frederick, Mutsuhito, and Alexander (now Woodbridge). One of the streets was also named after the Chinese emperor Kuang Su/Kuang Hsii but the street name was changed in the mid- $20^{\text {th }}$ century to "Lawrence" due to suspected anti-Chinese sentiments. The location was convenient because of its proximity to the Southern Pacific roundhouse where steam engines were maintained and turned around on the locomotive 
turntable for their journey back up the grade. Eventually, the neighborhood became known as "Little Italy" due to the high percentage of Italian railroad workers living there. Like many of the working class dwellings in the city, most of the houses in the neighborhood were "railroad vernacular” kit-houses (Figure 6.8).

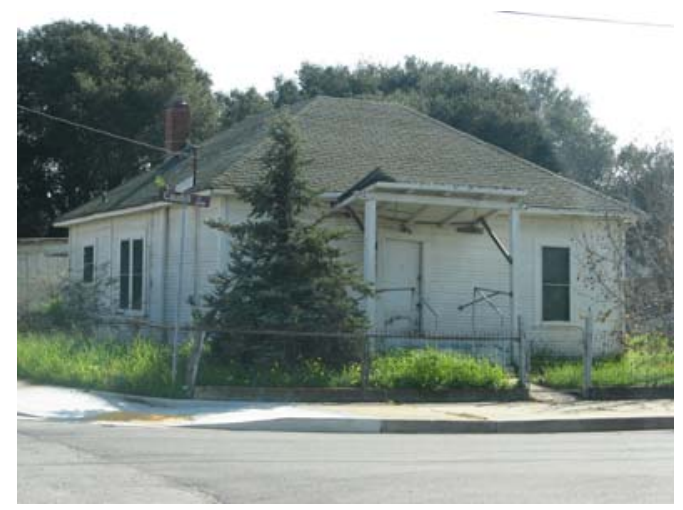

797 Caudill

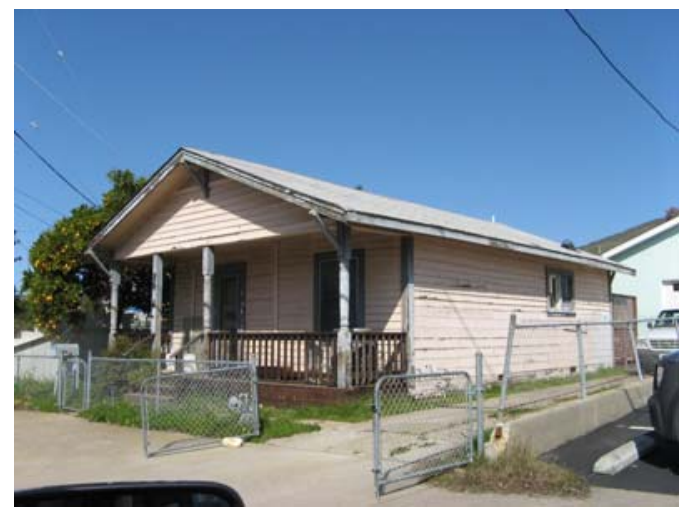

2502 Victoria

Figure 6.8: Two examples of "Imperial Addition" homes that typically housed railroad workers and their families. Photos: Adrianna Jordan.

In contrast, more middle class workers moved into the higher elevation neighborhood sited in the shadow of Terrace Hill between the Southern Pacific Railroad tracks and Johnson Avenue on streets such as Ella, George, and Swayzey. This neighborhood is now known as the East Railroad Page 75 
District/Brook Street Area and a number of railroad vernacular homes (Figure 6.9) have been cited for their historic contributions to the area. Notable homes related to the railroads are highlighted in Figure 6.10.

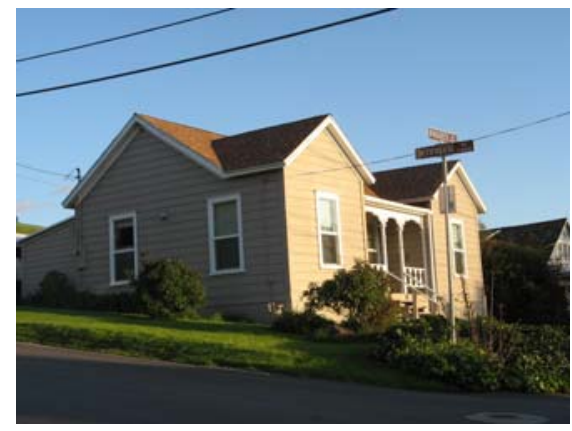

2006 Swazey - contributing

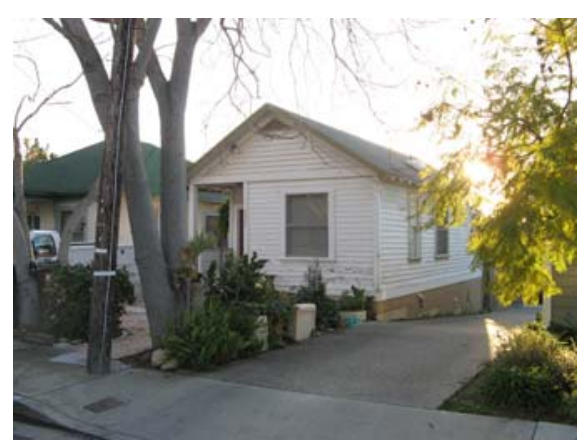

2027 Swazey - contributing

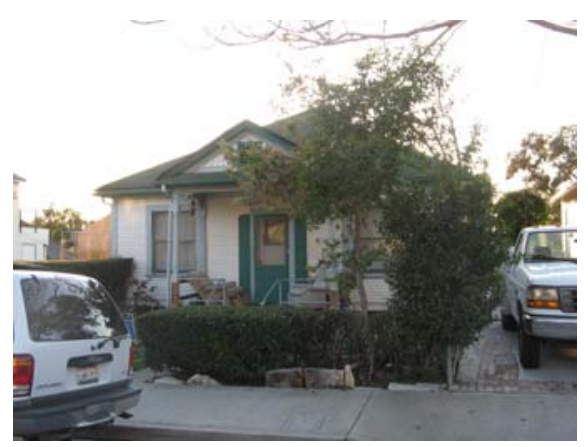

2033 Swazey - contributing

Figure 6.9: Three homes identified as potential contributors to the possible expansion of the Railroad District east of the railroad.

Photos: Adrianna Jordan. 


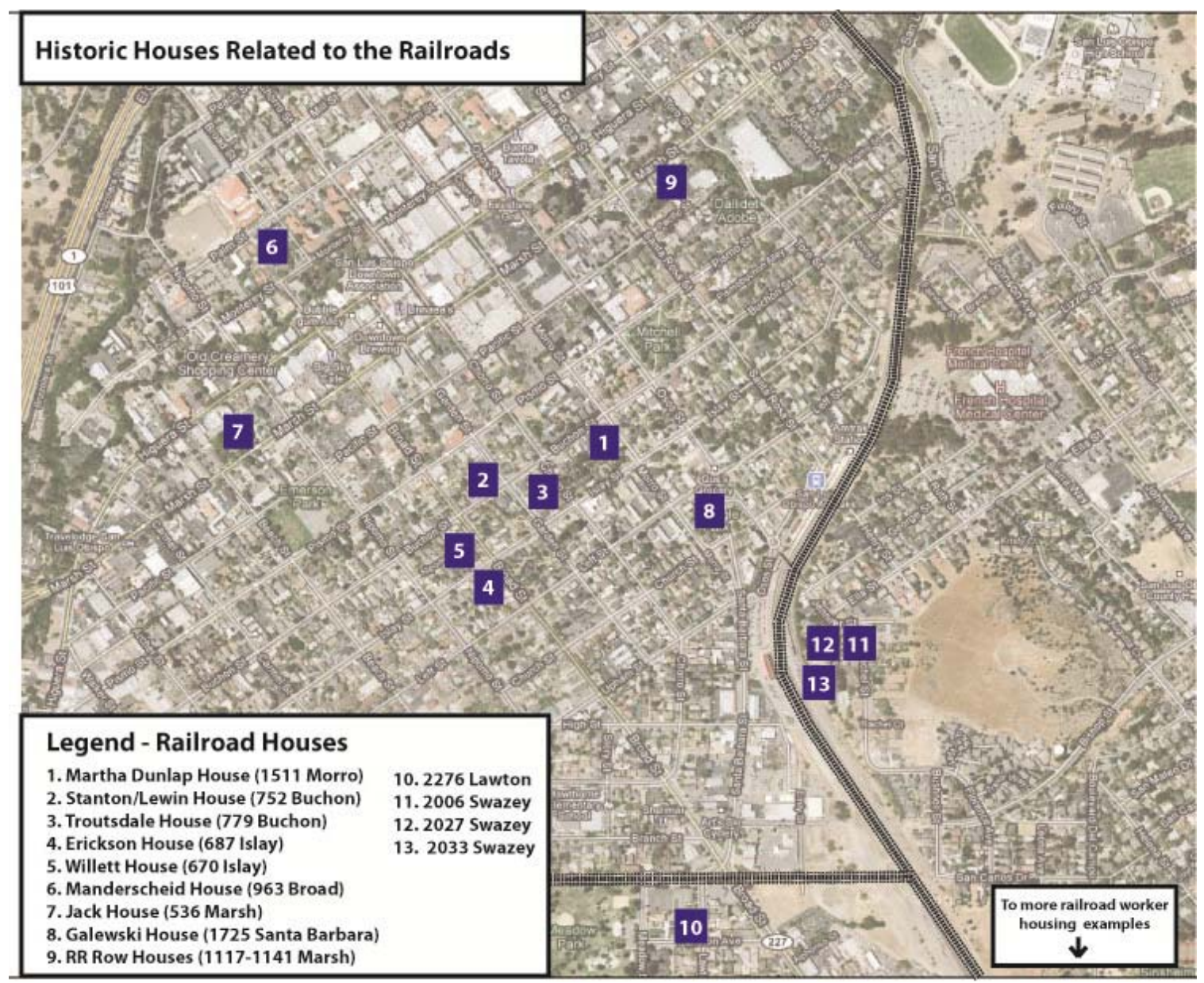

Figure 6.10: Notable homes related to the railroads. Graphic: Adrianna Jordan.

In addition to shifting the city's center away from the Mission, the Southern Pacific Railroad also attracted many new families to the city. Although the 1890s was a period of stagnant population growth for San Luis Obispo due to the economic depression, nearly 200 homes were built in the city in a span of 18 months between 1902 and 1904 and rented to workers for approximately $\$ 10$ per month (San Luis Obispo Fire Department, 1904). In response to all the new development, street paving began in 1908 and continued into the 1920s, and a sewer system and new streetlamps were installed around the same time period. 
The neighborhoods surrounding the Southern Pacific tracks continued to thrive through World War II when passenger rail traffic in the City of San Luis Obispo reached record numbers. However, after the war, the steam locomotives were gradually replaced by more efficient diesel engines that required less maintenance, and most of the local railroad workers found themselves out of a job. As the railroad's demand for workers diminished, the formerly thriving Imperial Addition neighborhood gradually turned into an industrial and warehouse area.

According to the book "San Luis Obispo: A History of Architecture", seven main architectural styles were used in the construction of homes and businesses. These styles include Adobe, California Renaissance, Spanish (Colonial), Contemporary Clapboard, Classical, Chicagoan, and Early American Commercial. Other popular styles for railroad-worker housing included California Bungalow, Mission Revival, Shotgun, and Cape Cod Saltbox. Whereas the Adobe, Spanish, and Mission styles were local to the area prior to the advent of the railroads, the other styles required access to railroad-transported goods. The typical construction of homes owned by railroad employees varied according to income, but most were simple bungalow kit homes ordered from Sears, Roebuck, and Company and built out of pre-cut redwood imported from places such as Santa Cruz and Redwood City (Figure 6.11). For those who could afford it, architects also designed many of the homes from this period and builder Harry Elmer Lyman was particularly active in the years between 1908 and 1928, constructing over 100 structures in and around the Railroad District, and especially along Upham Street. He favored 1,000 square foot California Bungalow style homes with porches. Nine of Lyman's properties are now on the city’s Master List of Historic Resources and four are on its contributing list. A notable example 
of his work is the Martha Dunlap House built circa 1916/1917 at 1511 Morro Street (Figure 6.12).

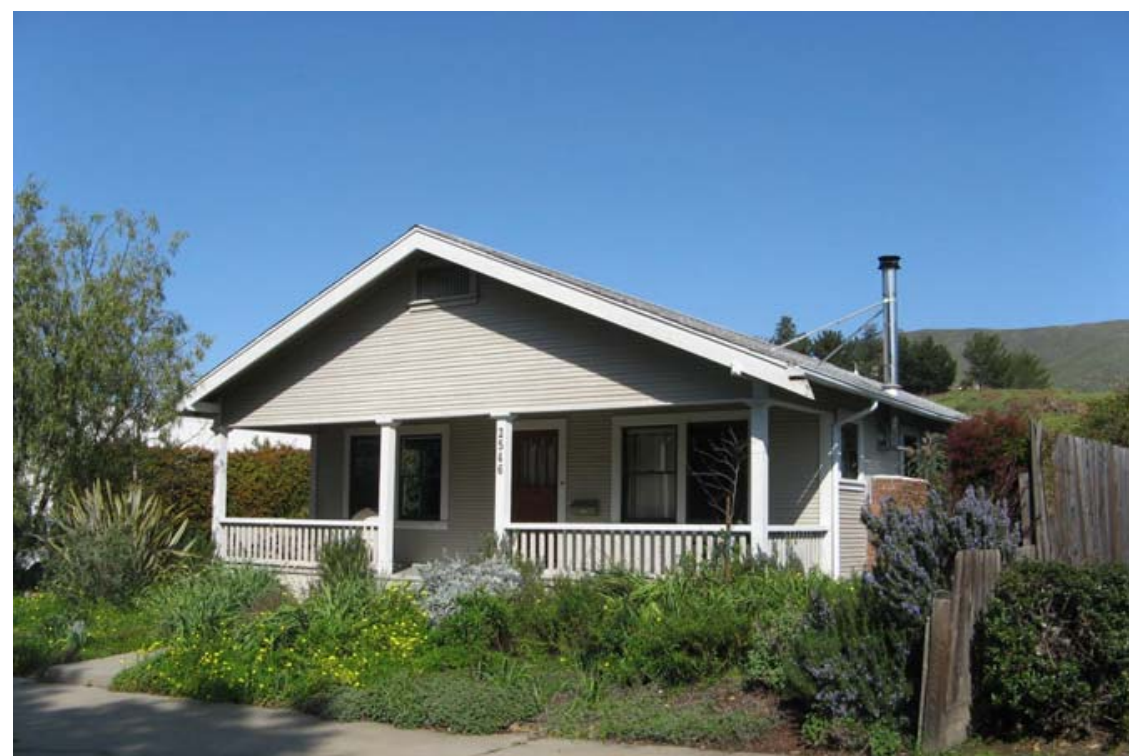

Figure 6.11: Typical railroad worker housing in San Luis Obispo. Photo: Adrianna Jordan.

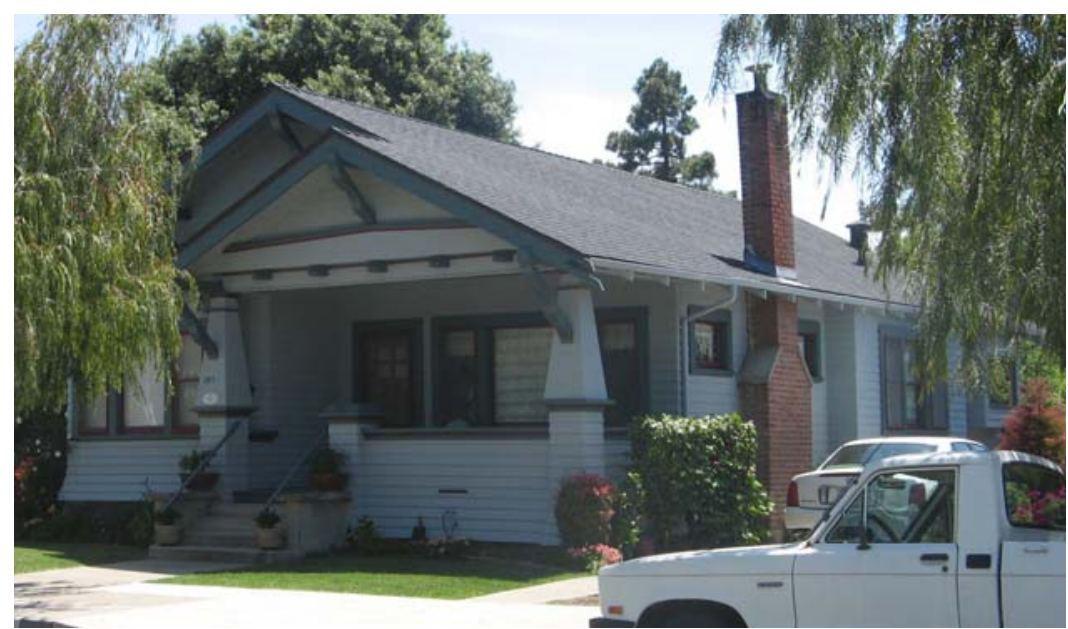

Figure 6.12: Martha Dunlap House at 1511 Morro Street. Photo: Adrianna Jordan.

Many well-known San Luis Obispo landmark homes have ties back to the railroad era. The Stanton/Lewin House at 752 Buchon Street (Figure 6.13) was constructed around 1902 by Edward Stanton who was an officer of the narrow-guage Pacific Coast Railroad. His wife, Irene 
Josephine Dana, was the daughter of Captain Charles William Dana, widely considered one of the main founders of the San Luis Obispo community. The home is notable for its bellcast roof, circular turrets, wrap-around porch, and stained glass windows.

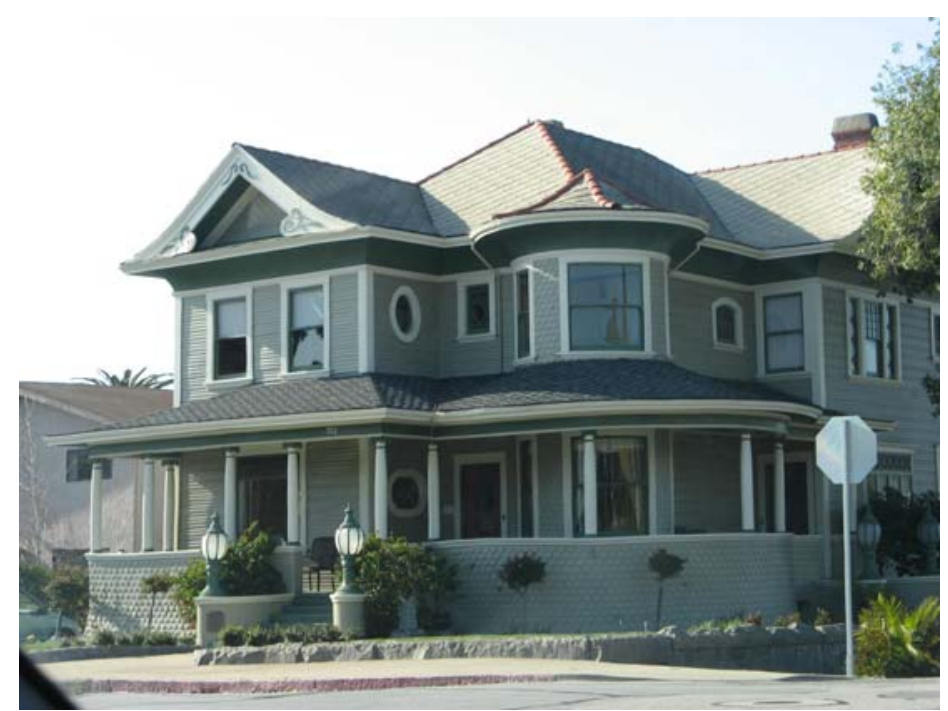

\section{Figure 6.13: Stanton/Lewin House at 752 Buchon Street Photo: Adrianna Jordan.}

The Carpenter Gothic Revival-style Troutsdale House at 779 Buchon Street (Figure 6.14) was constructed around 1904 by H.S. Troutsdale, a brakeman for the Pacific Coast Railroad. After changing ownership, it later housed local businessman J.P. Andrews when he moved in at the age of 90 to live with his daughter until his death in 1914. 


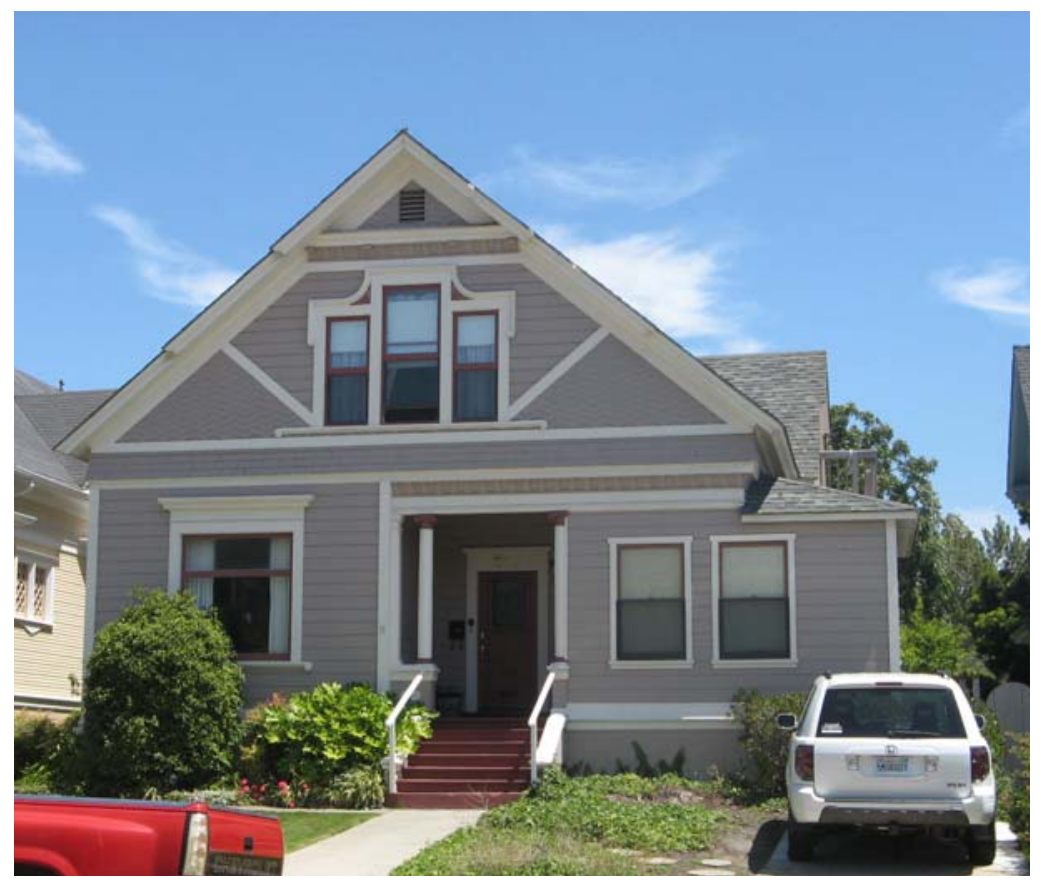

Figure 6.14: Troutsdale House at 779 Buchon Street Photo: Adrianna Jordan.

The Queen Anne-style Erickson House at 687 Islay Street (Figure 6.15) was constructed in the mid-1890s by Charles Erickson who was a contractor for the Southern Pacific Railroad from 1893-1906 and who was heavily involved with the construction of the Cuesta Grade tunnels. The home is notable for its turret, ornate peridment with "fish-scale” shingles, turned wood, and “keyhole” balcony. 


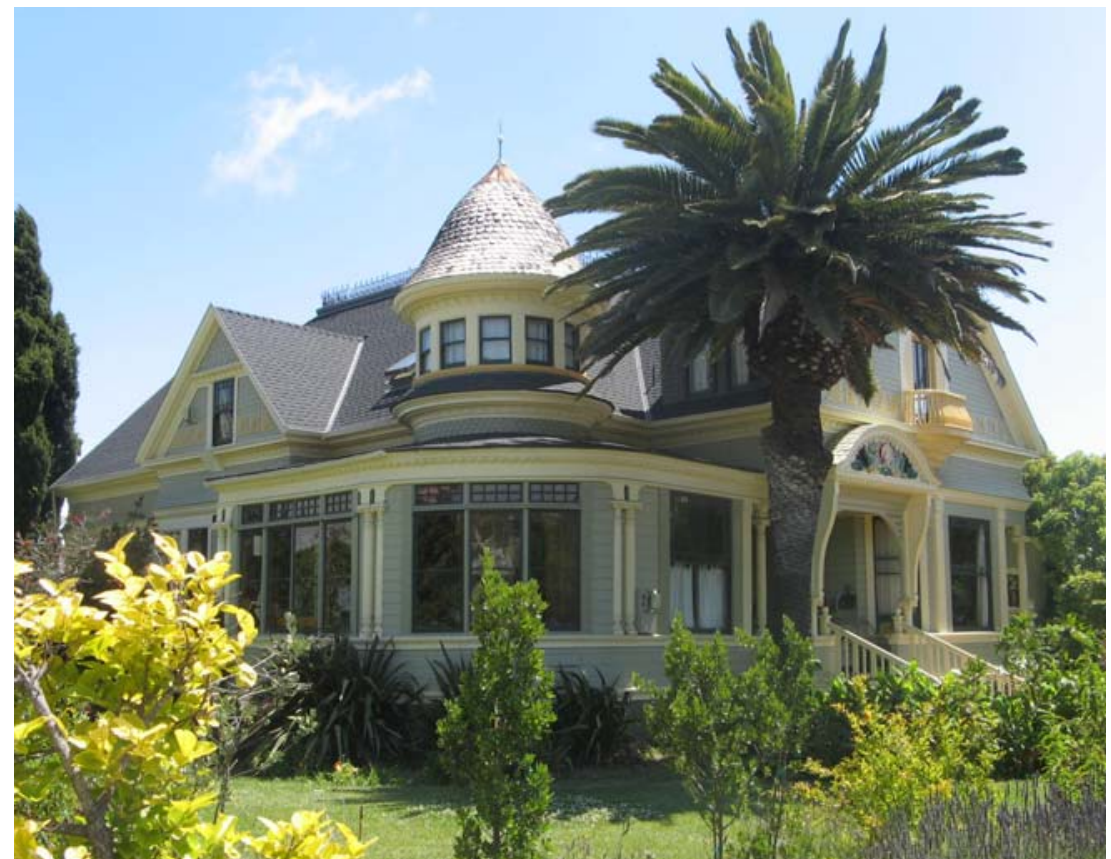

Figure 6.15: Erickson House at 687 Islay Street Photo: Adrianna Jordan.

The Jack House at 536 Marsh Street was constructed in 1882 by banker Robert Edgar Jack who made much of his fortune in land speculation tied directly to the advent of the Southern Pacific Railroad. He later became mayor of the City of San Luis Obispo from 1890 to 1893.

The Manderscheid House at 963 Broad Street (Figure 6.16) was built in 1891 and by 1914 it was owned by a Pacific Coast Railway condutor Richard Manderscheid. Additionally, the home located at 850 Buchon Street was owned around 1914 by Elmer Clark of the Pacific Coast Railway and mayor of the City of San Luis Obispo between 1908 and 1909. 


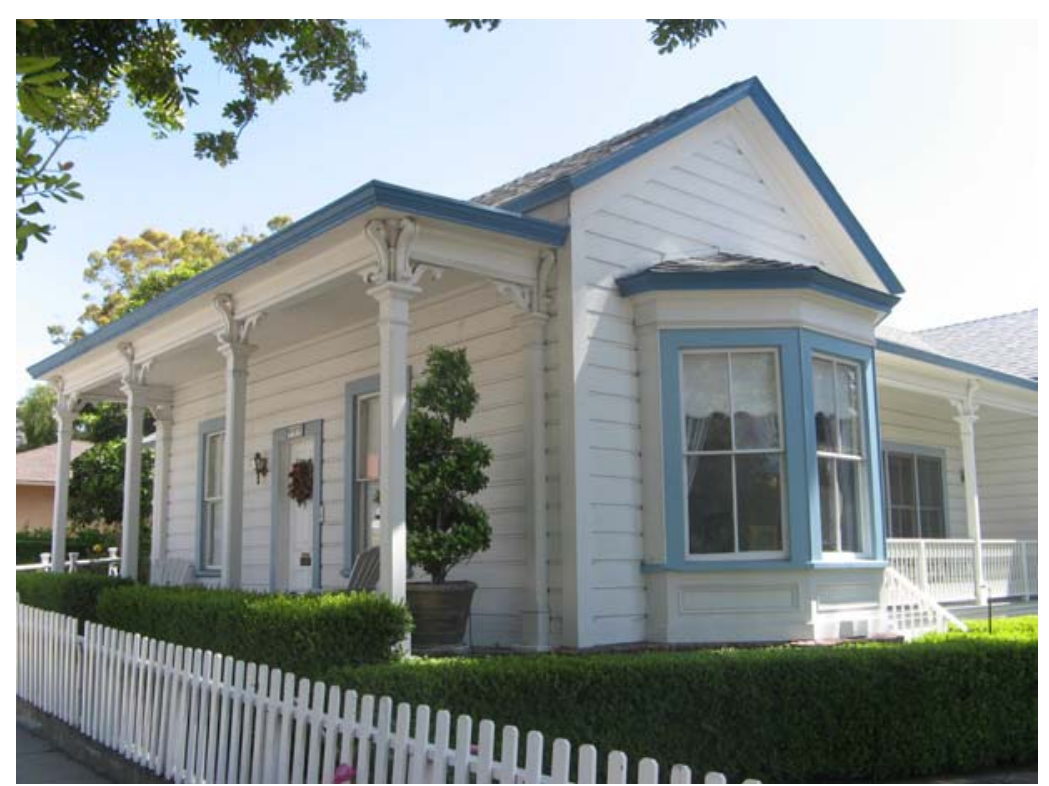

Figure 6.16: Manderscheid House at 963 Broad Street Photo: Adrianna Jordan.

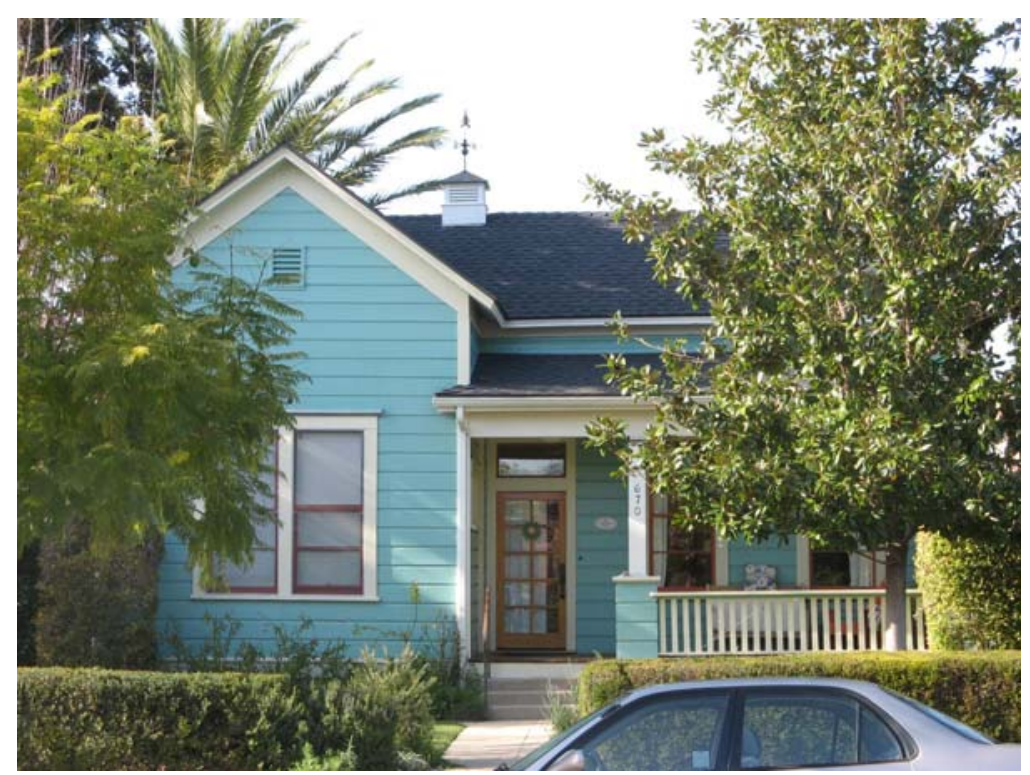

Figure 6.17: Willett House at 670 Islay Street Photo: Adrianna Jordan.

The Willett House at 670 Islay Street (Figure 6.17) was constructed in the 1880s and serves as an excellent example of the modest "railroad vernacular” style that was typically occupied by railroad workers and their families. Yet another good example of the "railroad vernacular" style 
is the Galewski House at 1725 Santa Barbara Street (Figure 6.18) which was built in1904 and owner-occupied for most of its existence.These types of homes were typically one-story, woodframed, and lacked decorative elements. Other examples of railroad worker occupied homes include the Greek Revival/Classic row houses built around 1880 and located at 1117, 1129, 1135, and 1141 Marsh Street (Figures 6.19 through 6.22 respectively). Occassionally, railroad workers would occupy shotgun-style houses such as the example at 2276 Lawton Street (Figure $6.23)$.

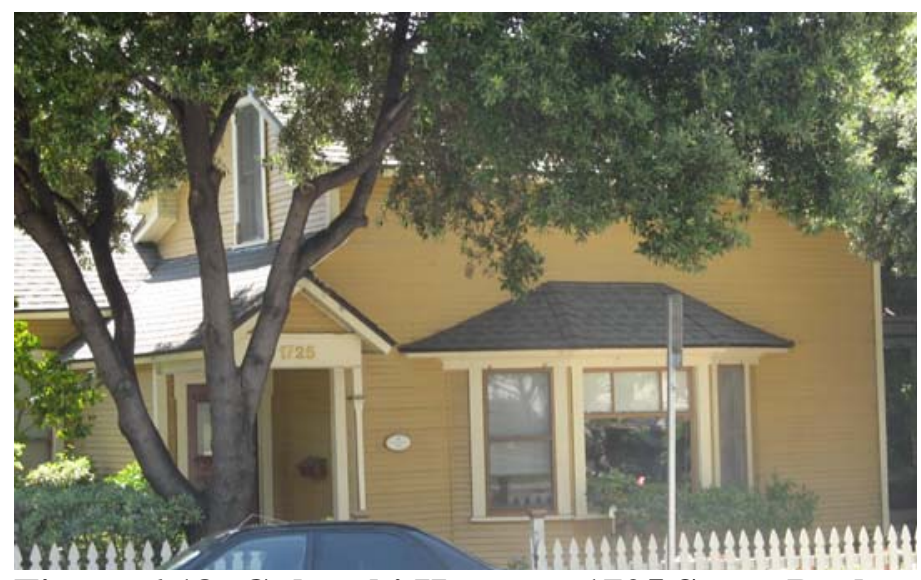

Figure 6.18: Galewski House at 1725 Santa Barbara Street Photo: Adrianna Jordan.

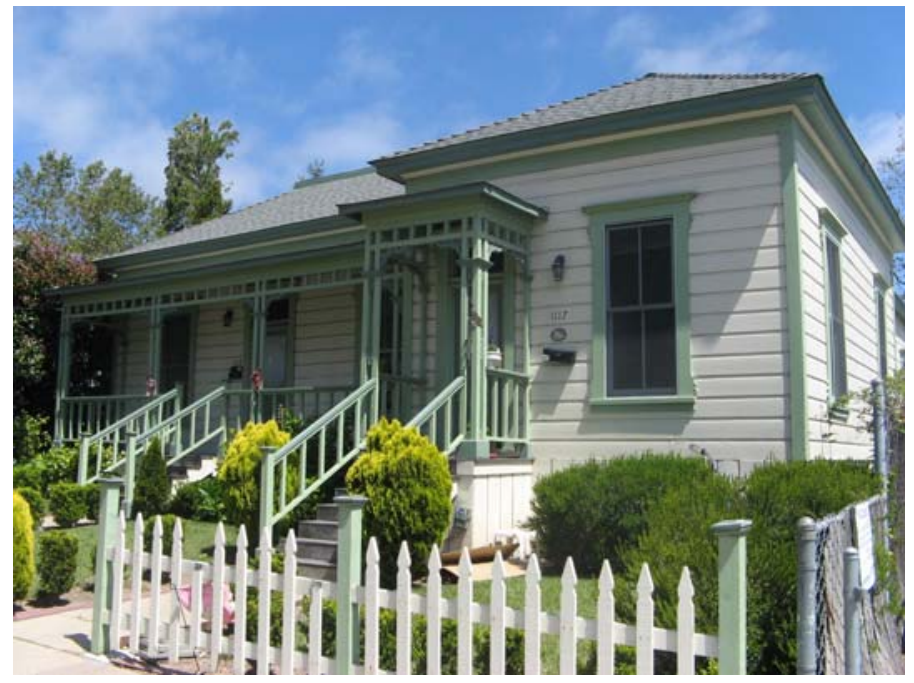

Figure 6.19: 1117 Marsh Street Photo: Adrianna Jordan. 


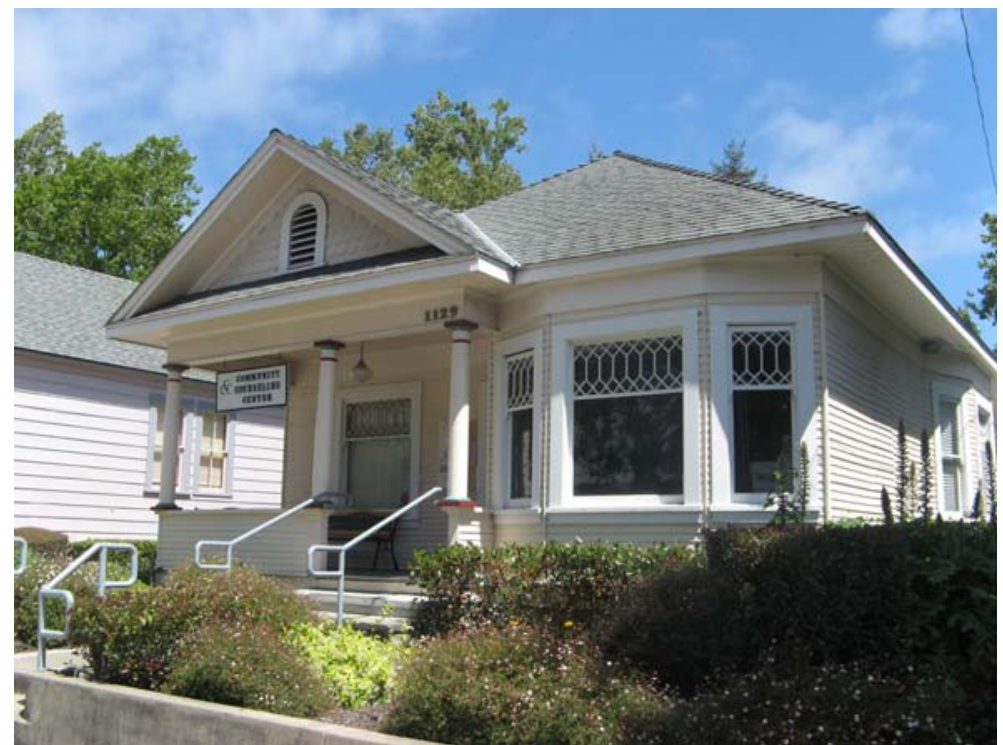

Figure 6.20: 1129 Marsh Street

Photo: Adrianna Jordan.

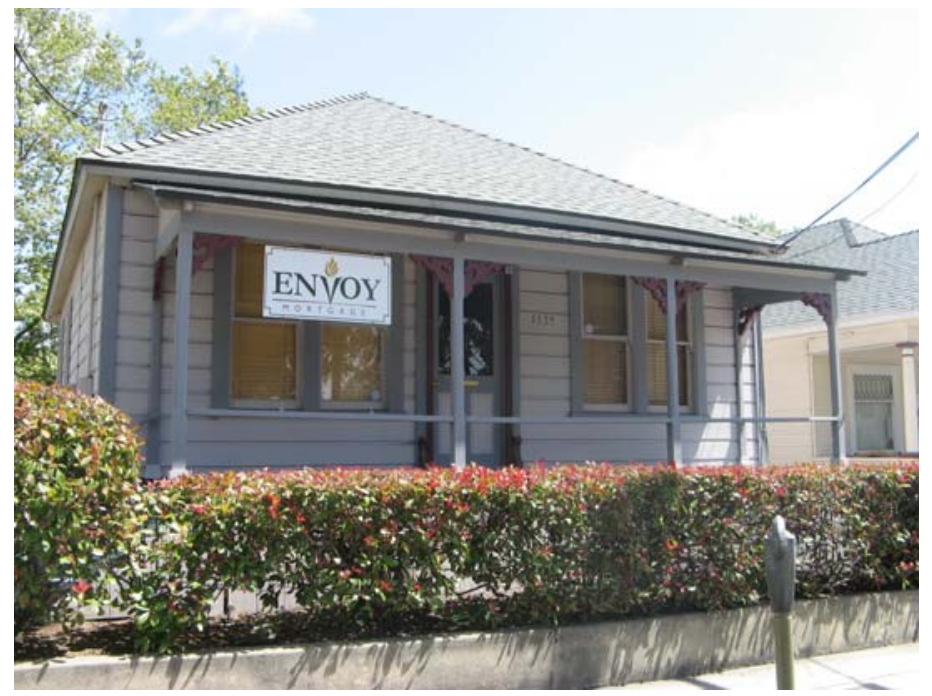

Figure 6.21: 1135 Marsh Street

Photo: Adrianna Jordan. 


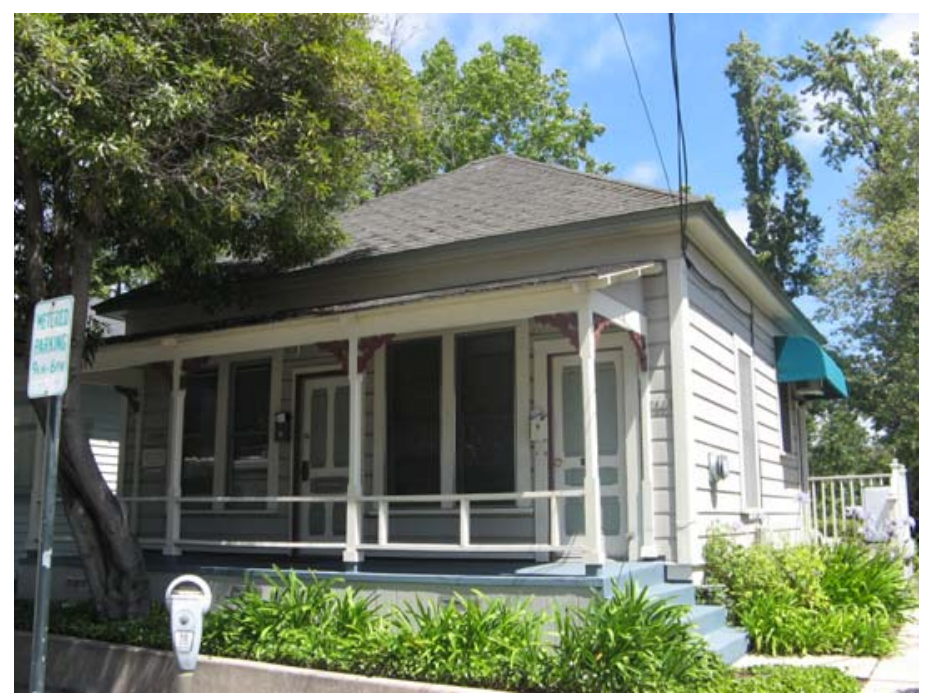

Figure 6.22: 1141 Marsh Street

Photo: Adrianna Jordan.

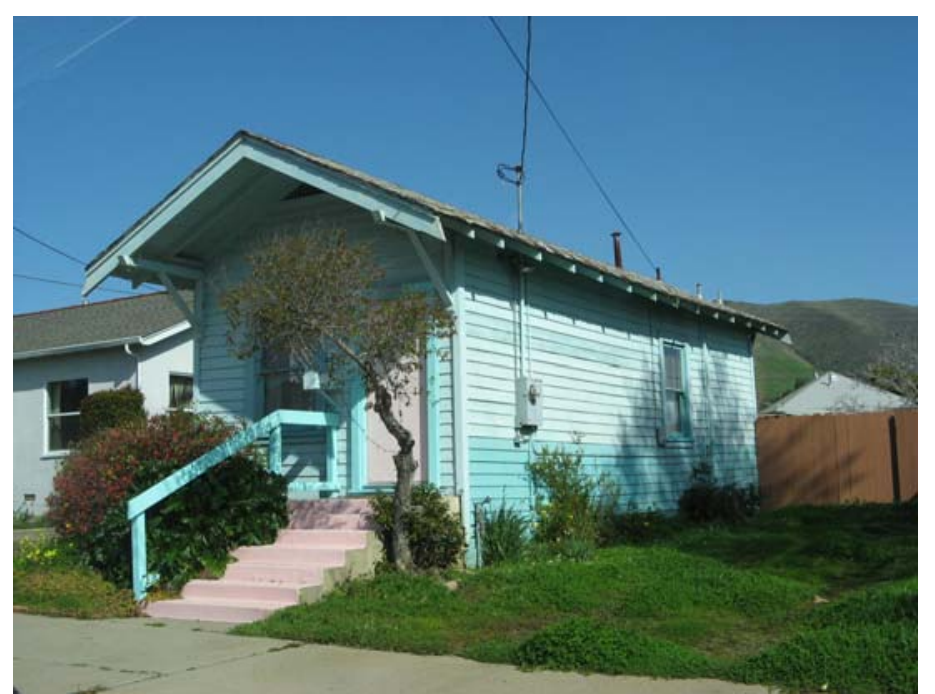

Figure 6.23: Good example of a "shotgun” house at 2276 Lawton Street Photo: Adrianna Jordan.

This chapter shows how influential the railroad exports (agricultural products) and imports (building materials) were on the population and character of the City of San Luis Obispo.

Chapter 7 takes a look at how the method of importing and exporting goods and people has changed in the $20^{\text {th }}$ century and debates whether the railroad can survive as a viable transportation option in the $21^{\text {st }}$ century. 


\section{Chapter 7: Reflection on the Railroads}

The previous chapter concentrates on the railroad's influence during the late $19^{\text {th }}$ century and how it permeated almost all aspects of everyday life for the citizens of the City of San Luis Obispo. Earlier chapters touch on the unwanted environmental impacts of the railroad on the early City of San Luis Obispo. Chapter 7 examines the role of the railroad in today's society and speculate on what the extent of its influence will be as we move through the $21^{\text {st }}$ century and consider re-embracing rail as a sustainable transportation solution.

\subsection{Transportation Eras in San Luis Obispo}

The history of modern transportation can be broken up into four distinct periods of time ${ }^{1}$. The first period of time is referred to as the "Walking-Horsecar Era" and lasted from 1800 to 1890. Characterized by towns and cities that grew in an organic circular manner and were traversed by foot, the Walking-Horsecar era ended around the time that the Southern Pacific arrived in the City of San Luis Obispo.

The second period in modern transportation is referred to as the "Streetcar Era" and lasted from approximately 1890 to 1920. It correlated with the height of railroad activity in the City of San Luis Obispo. In response to the linear tracks of the railroads and streetcars, most American towns and cities grew in spoke pattern during this time. In fact, the City of San Luis Obispo's own streetcar line (Figure 7.1), founded in 1887 by George P. Bell, began operations during this time and connected up to the Southern Pacific railroad at the Ramona Hotel terminal. Unfortunately,

\footnotetext{
${ }^{1}$ References for official transportation era names and dates retrieved on May $8^{\text {th }}, 2011$ from: http://people.hofstra.edu/geotrans/eng/ch6en/conc6en/evolurbformna.html 
this period was short-lived due to the advent of the automobile and the third era of modern transportation and by 1901 the streetcar line was already out of business (San Luis Obispo History Center, n.d.).

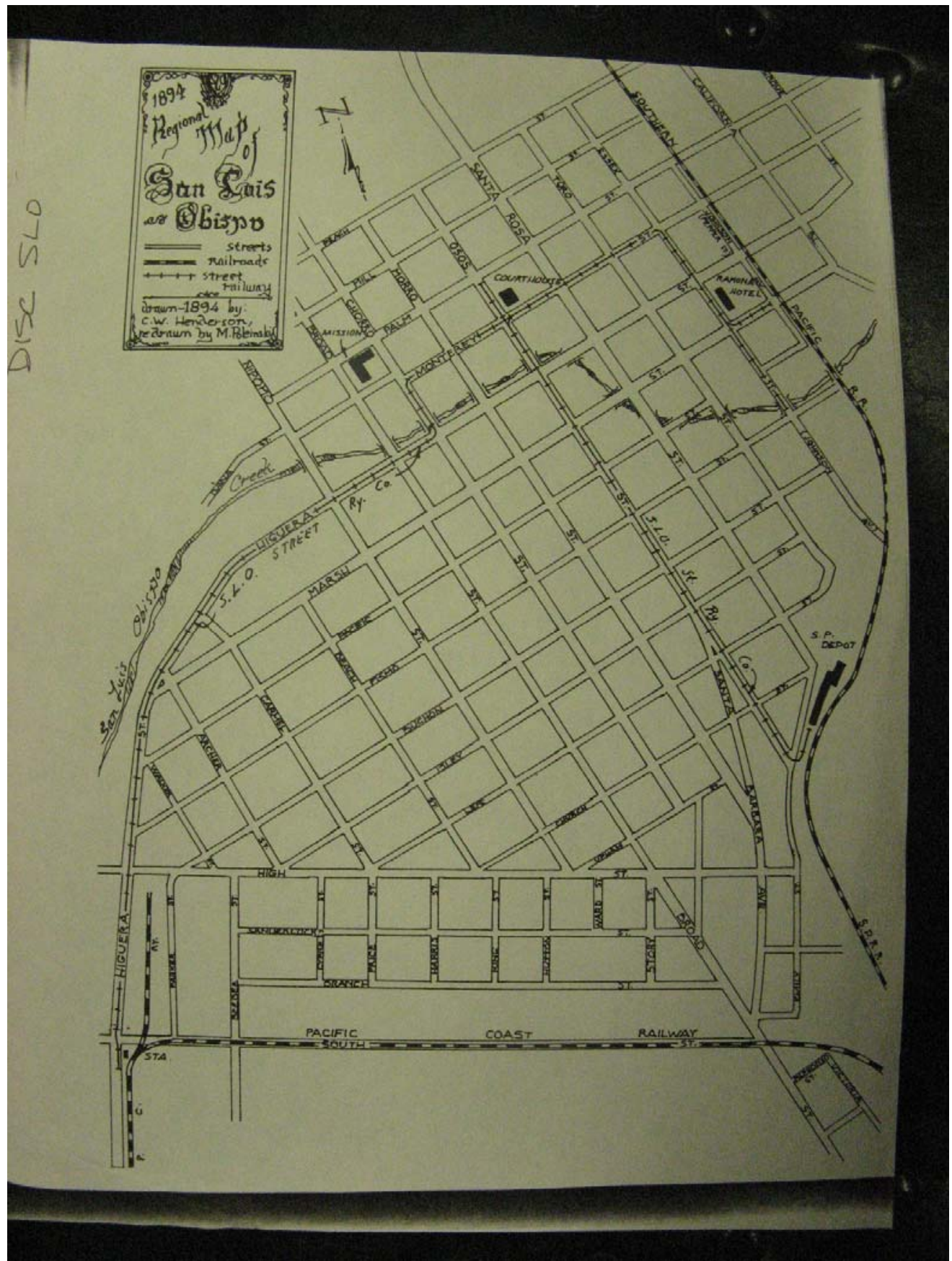

Figure 7.1: Map of the San Luis Obispo Street Railway. Map courtesy of the San Luis Obispo History Center. 
Starting around 1920 and lasting until the second World War, the "Automobile Era” was marked by the rise of the car and the demise of public transportation, in particular, "fixed rail" public transportation such as streetcars and the railroads were most directly affected. In 1941, following in the footsteps of the streetcar line decades before, the Pacific Coast Railway itself became defunct. The great advantage of the automobile was that it opened up large areas of land that were previously undevelopable because there was no reliable form of transportation available to reach them. The downside of this was that demand for the fixed route systems diminished as the local population dispersed across a wider area. By the end of the "Automobile Era", the only fixed route transportation system in the City of San Luis Obispo to survive was the Southern Pacific Railroad.

The final stage in the evolution of modern transportation took place during the post-war era and is commonly known as the "Freeway Era". This era was especially hard on the railroads; the freeways enabled the automobile to replace the low-cost long-distance travel that the railroads typically provided to their passengers. Due to declining revenues, essentially all railway passenger service in the United States was taken over by the federally owned Amtrak Corporation immediately following its formation in 1971. Up until this point, the Southern Pacific had been running the Coast Daylight train between Los Angeles and San Francisco. After Amtrak's consolidation of passenger rail service, the Coast Daylight was replaced by the Coast Starlight which continues to run between Seattle and Los Angeles but has longer run times than the Daylight between Los Angeles and San Francisco and is less reliable. Due to increasing commuter pressure to have a faster, more reliable route with better station stop times, the Coast Daylight is scheduled to resume service between Los Angeles and San Francisco around 2012. 
The Freeway Era is well-known for its booming suburbs that leap-frog across wide swaths of undeveloped land. It also signaled a slight return to the linear configuration of urban communities because most of the suburbs were located in a straight line from the core urban center along the freeway. In the case of the City of San Luis Obispo, open space preservationists were relatively successful in preventing excessive sprawl, although elements of sprawl are detectable in the new southern suburbs of San Luis Obispo along South Broad Street and South Higuera Street and west along Los Osos Valley Road; however, to a certain extent some sprawl is inevitable as cities struggle to balance population growth and land conservation.

\subsection{The Influence of the Airport on Land Use and Development}

Arguably, a sub-era in the evolution of the City of San Luis Obispo could be considered the "Era of Flight”. Although planes have existed since the Streetcar Era, the regional airport in San Luis Obispo was not constructed until 1940. Passenger service did not begin until 1946, and a control tower was not constructed until 1988. Much like the Southern Pacific, the San Luis Obispo County Airport had a huge influence on land use in the city. Since its construction, almost all of the new residential and commercial development has been located in the southern portion of the city, relatively close to the airport. Additionally, due to Federal Aviation Administration regulations, there is a large area of land in the county just outside of the city limits where development is restricted because it is in the direct flight path of the airplanes. This swath of land is prominently noticeable in the aviation safety map for the southern portion of the City of San Luis Obispo (Figure 7.2). 


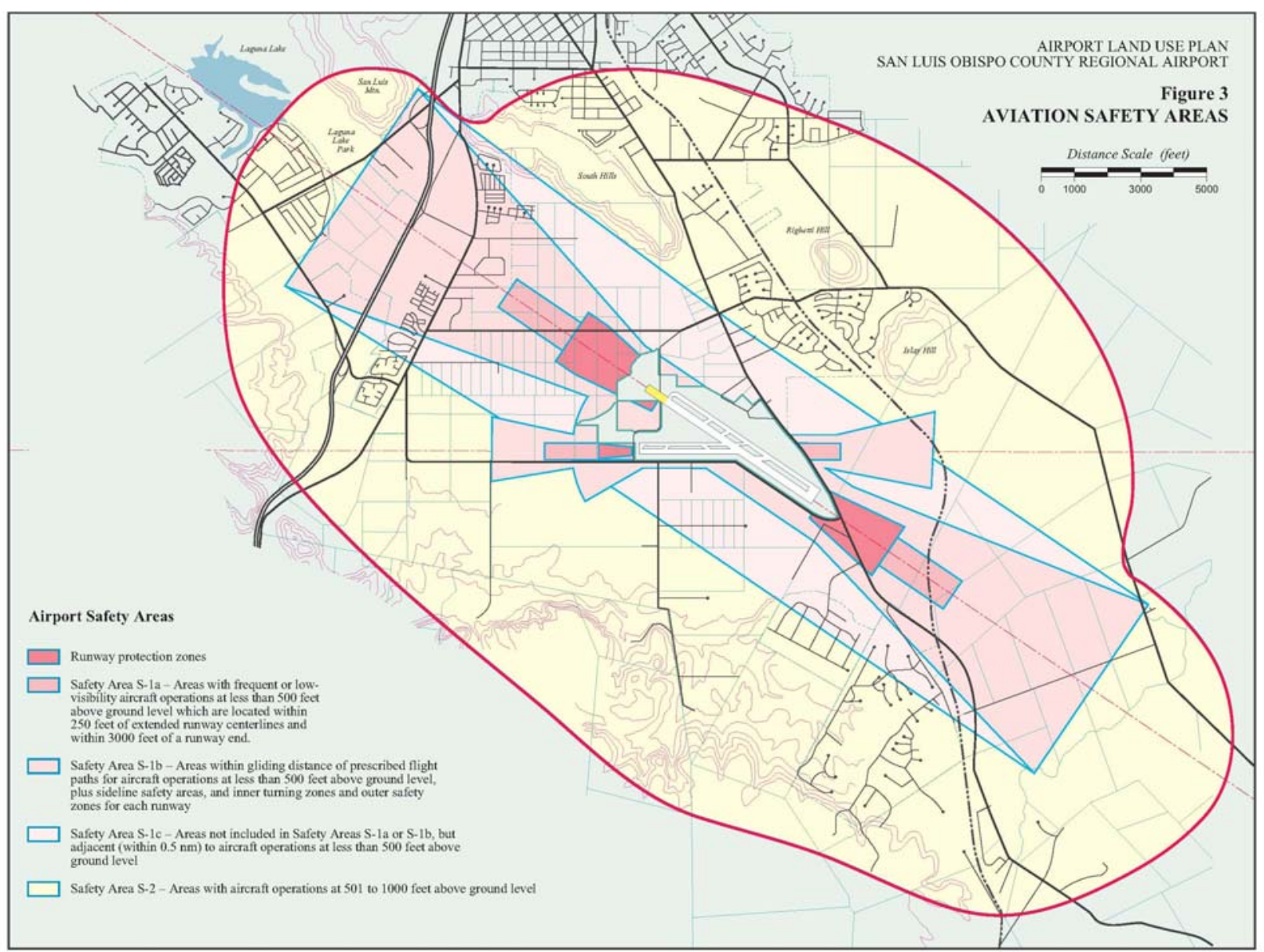

Figure 7.2: Aviation safety map of the southern portion of the City of San Luis Obispo. Courtesy of the San Luis Obispo Airport Land Use Plan (2011).

The flight path safety areas extend northwest in a diagonal band from the San Luis Obispo County Airport, eventually crossing Tank Farm Road which was the site of a lightning strike in 1926 that ignited a fire resulting in ground contamination from leaking oil tanks on both the north and south sides of Tank Farm Road. This severe contamination stymied development in the area long before the airport further limited development of the land; however, Chevron is currently taking steps to remediate the contamination and hopes to eventually build an office park on the site (City of San Luis Obispo, 2009). 


\subsection{The Union Pacific's Continued Influence on Land Use in the}

\section{$\underline{\text { City }}$}

Much like the restrictions on development around the airport, certain historical restrictions persist on the development of the land around the Union Pacific railroad tracks. For instance, the Union Pacific owns a 100 foot right-of-way (50 feet on each side) centered over their tracks through the City of San Luis Obispo. Anyone who enters the right-of-way is considered to be trespassing on Union Pacific property and can receive a ticket with a hefty fine if caught by Union Pacific Police. Obviously, this right-of-way issue has created land use conflicts in terms of the bicycle path that runs adjacent to the tracks, as well as public uses such as exhibition spur tracks associated with the forthcoming Railroad Museum.

\subsection{The Rise of the Southern Pacific as a Freight Railroad}

Although the Southern Pacific railroad started out carrying both freight and people, following the transfer of passenger services in 1971, it concentrated exclusively on shipping freight. However, the railroad could not easily compete with the geographic flexibility of the trucking industry, and by the late 1980s, the Southern Pacific was in a state of financial insolvency. Due to this financial instability, the Southern Pacific was taken over by Rio Grande Industries in 1988, but continued to retain the brand name Southern Pacific for the rail route through the City of San Luis Obispo. Following further financial troubles, the Southern Pacific was acquired by the Union Pacific in 1996. It was during the following year in 1997 that the historic locomotive turntable was demolished in the City of San Luis Obispo. It is worth speculating that the fresh acquisition by Union Pacific was playing a substantial role in the dismantling of various 
Southern Pacific artifacts that had remained in the San Luis Obispo rail yard through the 1990s. It is good business practice to "clean up" remnants of the acquired business if there is a possibility that the remnants could create environmental issues; therefore, this may have been the reasoning behind the Union Pacific’s dismantling of much of the remaining rail yard.

Today, Union Pacific hauls a variety of freight types. The Union Pacific California business mix is: $49 \%$ intermodal, $17 \%$ agricultural products, $15 \%$ industrial, $10 \%$ cars, $7 \%$ chemical, and $2 \%$ energy-related (Union Pacific, 2010).

\subsection{The Future of Passenger Rail in the City of San Luis Obispo}

As previously mentioned, the Coast Daylight is scheduled to resume service around 2012. When the original Coast Daylight was taken over by Amtrak in 1971 it took approximately 10 hours to travel from San Francisco to Los Angeles; however, due to the Union Pacific’s track monopoly and lack of up-to-date track maintenance, when the Coast Daylight starts back up again it will take approximately 12 hours to run between San Francisco and Los Angeles. Obstacles that increase the running time for the new train include a lack of "sidings" along the route and antiquated switching mechanisms.

Railroad "sidings" are the parallel tracks that a train can pull into to wait for a train running in the opposite direction (that has the right-of-way on the track) to pass by. If there are not enough sidings, that can substantially increase delays; this is especially true if the train running in the opposite direction is already behind schedule. Caltrans is working with the Union Pacific to fund 
and build new sidings along the San Luis Obispo to Los Angeles route such as the underdevelopment "Ortega” siding which is located in Summerland, California just east of Santa Barbara and the "Seacliff” siding just west of Carpinteria, California. In addition, although automated track switching mechanisms exist, they are so prohibitively expensive that the Union Pacific cannot afford to replace their antiquated manual track switching devices with automatic track switching devices. Unfortunately, using old technology also increases track delays.

The new Coast Daylight cannot run without acquiring the appropriate rolling stock. For its existing Surfliner route, Amtrak uses an EMD F59PHI diesel locomotive or as a backup a GE P32-8WH (Dash8) diesel locomotives and "California" cars which are a variant of the Superliner train cars. In addition, for its Coast Starlight route, Amtrak uses GE P42DC AMD-103 Genesis series locomotives or GE P32-8 (Dash 8) locomotives as a back-up, and uses the Superliner cars (Figure 7.3) to carry passengers. Furthermore, efforts are being made to secure new rolling stock for the revived Coast Daylight train. In addition, it was announced on May 2, 2011 in the San Luis Obispo Tribune that the Pacific Surfliner would also be replacing the single-level cars with nine new double-decker cars by 2017 thanks to a grant from the Federal Railroad Administration. 


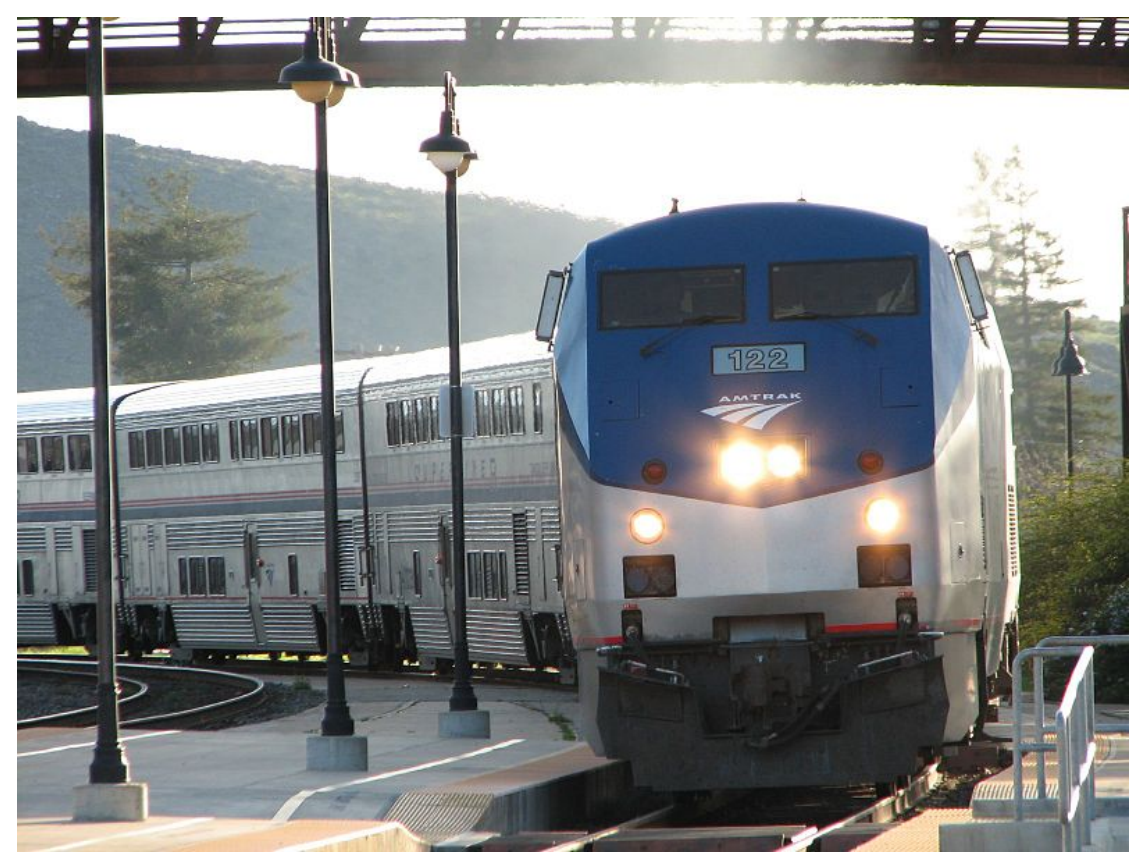

Figure 7.3: Amtrak Coast Starlight Locomotive and Superliner Cars in San Luis Obispo Photo Courtesy of Wikipedia Coast Starlight (n.d.)

Eventually, through track and other operational upgrades, the new Coast Daylight trains will be able to complete their trips in eight hours. At the moment, one train per day in each direction is planned to run two hours earlier than the Coast Starlight so that each train will arrive at its destination around 7 pm (Monterey Peninsula Information, 2011).

\subsection{Sustainability and the Railroad}

Although in recent decades the railroad's competitive strength against more modern forms of transportation such as cars, trucks, and planes has diminished, it is now poised to make a comeback in light of concerns about climate change and the future of oil. Unlike cars or trucks which have a limited capacity, railroads can typically transport very large numbers of people or freight using relatively little energy. In addition, unlike planes, trains do not require an 
increasingly expensive and scarce fuel such as jet fuel to operate because modern trains can run using either diesel fuel or electric locomotion.

The great disadvantages that trains have continue to be their limited geographic reach, their fixed routes, and their low speed. Although there is very little that can be done about the former, the California High Speed Rail will address the speed issue by competing directly with cars and planes since it is expected to reach speeds up to 220 miles per hour when it is finished sometime around 2026 (Cox and Vranich, 2008). Even though the City of San Luis Obispo is not located along the proposed route for the new high speed train, regional transportation will still be shaped by its presence through Amtrak buses that will most likely make runs out to the proposed Hanford high speed rail stop in the Central Valley thus connecting the city with the high speed rail. However, it stands to be seen whether ridership on Amtrak buses and trains will increase or decrease due to the new train. If the new train merely pulls people off of the slower coast trains without increasing state rail ridership overall, then the ridership through the City of San Luis Obispo could actually decrease. Yet, if the new train attracts new riders that never previously considered taking the train then activity at the San Luis Obispo station could actually increase. Much of the speculation about ridership ultimately hinges on the price of gasoline. If prices continue to rise, the bottom line is that more people will ride the train. The first segment of line is proposed in the Central Valley because of the high volume of population that regularly commutes into the large cities from the valley.

Recently, the Union Pacific began to re-brand itself as a kind of "green" transportation option and they tout an impressive number of facts about the environmental advantages of using trains 
for hauling freight instead of trucks. Among them, one double-stacked train removes a staggering 280 trucks from the roads, trains are nearly four times more fuel efficient than trucks, trains emit 1/3 the amount of Green House Gases (GHGs) of trucks on a ton-mile basis, and finally, trucks emit two to three times the amount of Nitrous Oxide (NOx) as trains on a ton-mile basis (Union Pacific, 2010).

Obviously, trains are just as much of a sustainable option for passengers as they are for freight. In 2007, the Amtrak Surfliner carried 2,685,194 passengers, or 136.1 passengers per mile and eliminated almost two million inter-city car trips (California Department of Transportation, 2008). In turn, the elimination of these car trips leads to large-scale reductions in GHG emissions including carbon dioxide, methane, nitrous oxide, and ozone.

The positions of Amtrak and the Union Pacific are further strengthened by recent California legislation including Assembly Bill (AB) 32 and Senate Bill (SB) 375. AB 32 deals directly with climate change and it mandates a reduction in Green House Gases (GHGs) to 1990 levels by 2020. SB 375 is intended as an implementation tool for AB 32 and requires communities to prepare Sustainable Community Strategies (SCS) documents that show a balance and nexus between land use and transportation. The centralized nature of railroads will likely elevate their profile as part of the strategy to better connect land use and transportation and subsequently lower GHGs by reducing car and truck trips through increased passenger rail and freight rail use.

The role that railroads can play in the future as they re-create their public image as a "green" form of transportation benefitting the environment is exciting. Chapter 8 continues the discussion 
of branding the experience of the railroad but concentrates on branding as it relates to tourism rather than sustainability; however, it also highlights sustainable modes of transportation that are new to the Railroad District and easily accessible to tourists and locals alike. 


\section{Chapter 8: A Conceptual Plan for the Future Role of Railroads in the City of San Luis Obispo}

The prior chapter demonstrates that railroad companies are savvy enough to re-market themselves as sustainable transportation providers. This last chapter provides an overview of the creative development tools available to help energize efforts to re-market the historic Railroad District as a tourist destination. The chapter also includes a discussion of how other locations with similar amenities have reached their full potential as niche railroad tourist towns.

\subsection{Tourism in Today's City of San Luis Obispo}

Scenically situated between the ocean and the mountains, the City of San Luis Obispo has few of the type of urban tourist attractions that typically make hub cities economically successful, yet it remains a regional tourist destination stemming from the time period of the luxurious Ramona Hotel. There are no major parks and no major public cultural facilities, with possible exception to the Christopher Cohen Performing Arts Center. Nonetheless, the mild climate, scenic beauty, Pacific Ocean, historic mission, local wineries, and quaint downtown make it a popular regional weekend destination. Adding to these assets, the City of San Luis Obipo benefits from a railroad yard in remarkably good condition. Therefore, it would be beneficial to market the historical transportation assets as a cornerstone of the tourism-based local economy. 


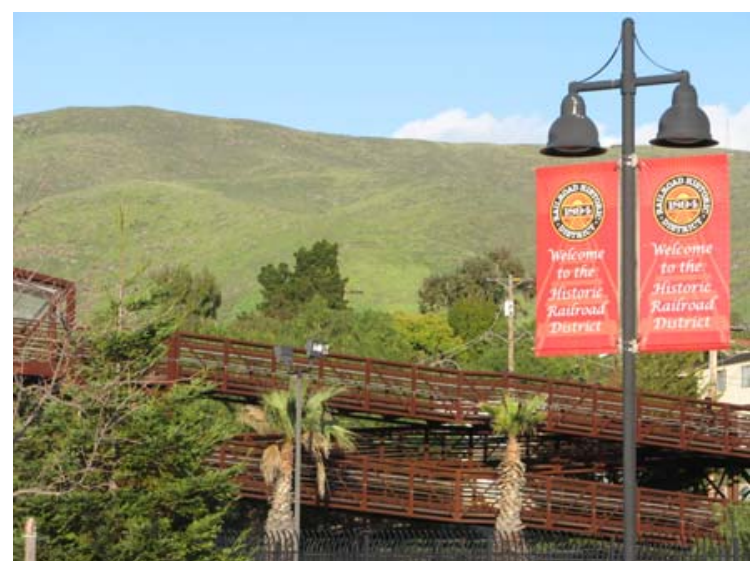

\section{Figure 8.1: The Jennifer Street Bridge in the Railroad District} Photo: Adrianna Jordan.

The ongoing revitalization of the railroad district (Figure 8.1) is a key component in the preservation of the city's historic resources, and in the quest to increase visitors to the area. The development of the Railroad Museum (Figure 8.2) is anticipated to provide the district with a cultural hub and greatly increase niche tourism due to a new influx in railroad-enthusiast related and educational-group related tourism. In addition, in order to channel visitors between the downtown and the railroad district, it is advisable to strengthen physical links between the Railroad Museum and the County Historical Museum (Figure 8.3). If a tourist is interested in visiting one of these places they may benefit from visiting the other one as well because both museums showcase local history.

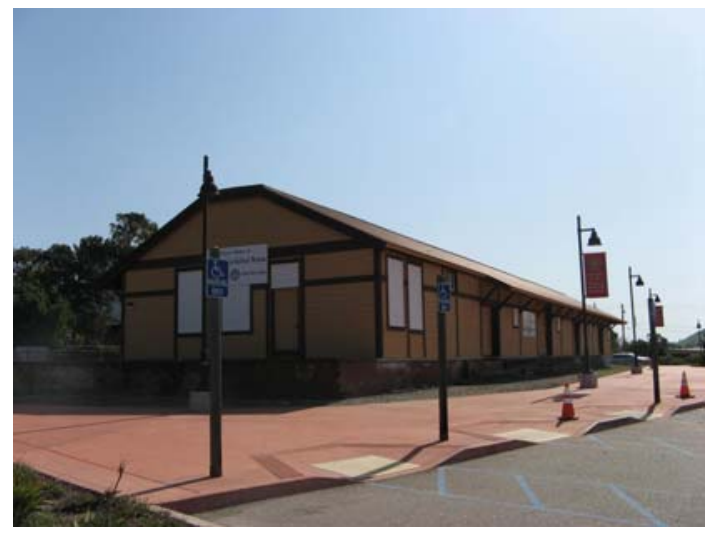

Figure 8.2: The Historic Freighthouse Building that will House the Railroad Museum Photo: Adrianna Jordan. 


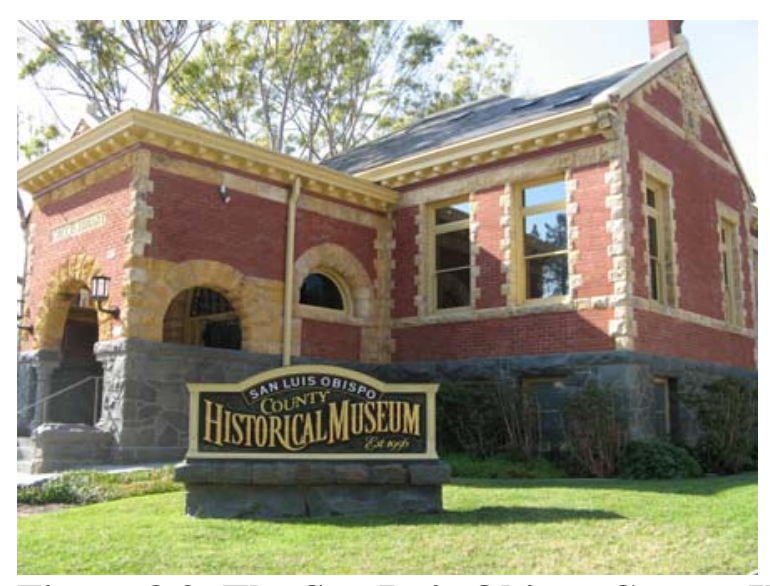

Figure 8.3: The San Luis Obispo County Historical Museum Photo: Adrianna Jordan.

Certain civic organizations such as Heritage Shared have been quite active in publishing tourist guides detailing historic walking or biking tours including a tour focusing the railroad. ${ }^{1}$

Additional tour ideas to connect the downtown and the Railroad District include the potential for a bicycle tour focusing on sustainable businesses which could start in the Railroad District at a bicycle rental facility.

In addition to creating linkages between the downtown and the Railroad District, a fully integrated City of San Luis Obispo railroad history tourist circuit would not be complete without a connection to Port San Luis and the historic Harford Pier and remnants of the Pacific Coast Railway. Possibly, the uncompleted Bob Jones Trail could serve as the main pedestrian and bicycle connection between the city and the pier and perhaps a tour guide could be created for this area pointing out Pacific Coast Railway historic resources. Port San Luis has recently

\footnotetext{
${ }^{1}$ Most of the Heritage Shared guides were published by Bruce Collier and Dick Miller. Barbara Machalo and Astrid Gallagher are the contacts for the group at (805) 549-9283 and (805) 549-9283, respectively.
} 
undergone a much-needed revitalization effort and now boasts extensive educational signage as well as new public art that highlights the importance of the railroad to the region (Figure 8.4).

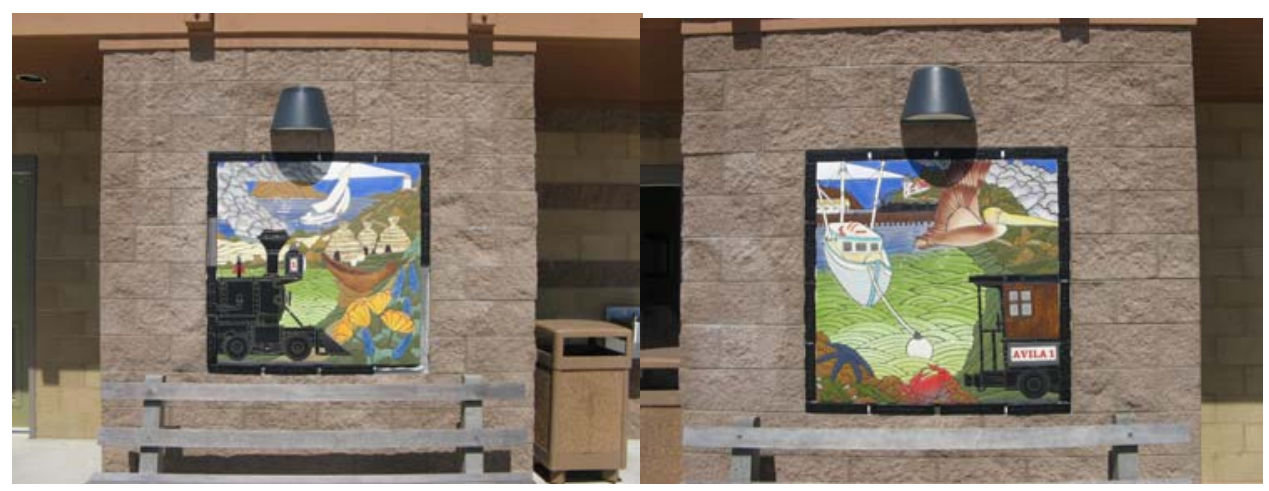

Figure 8.4: New public art at Port San Luis highlighting the Pacific Coast Railway Photo: Adrianna Jordan.

\subsection{The Railroad District Revitalization Plan}

Adopted in 1998, the Railroad District Revitalization Plan, which won an award from the American Planning Association (APA) in the "small cities" category, has been very successful in its implementation. In the time that has elapsed between the adoption of the plan and today, the Jennifer Street Pedestrian and Bicycle Bridge has been constructed and now links the Terrace Hill neighborhood to the downtown; the memorial sculpture to the Chinese railroad workers was erected; the Park Hotel has been restored; surface vehicular parking has been increased, bicycle racks have been installed, the Railroad Safety Trail was developed, the Railroad Museum moves closer to its grand opening, and the Coast Daylight route prepares to resume service. In addition to providing a kind of blueprint for long-term development of the area, the plan also emphasized the preservation of the area's architectural character. The success of the architectural design guidelines is on display in district buildings such as the Iron Horse Station built by Rarig Construction in 1998 (Figure 8.5). 


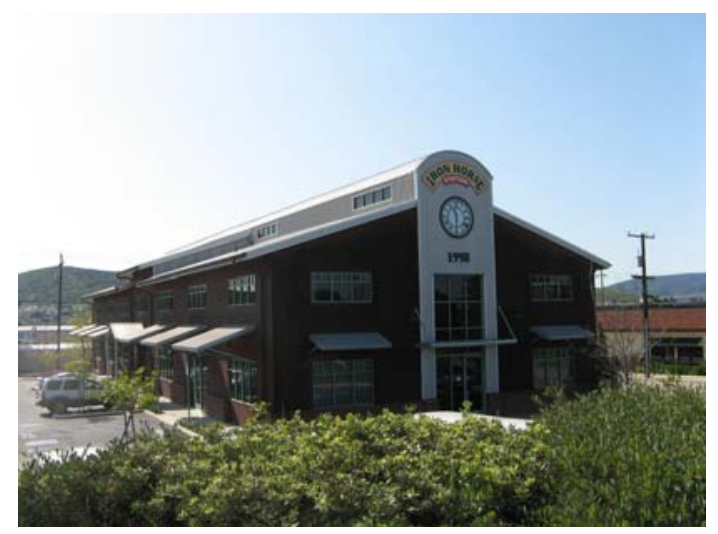

Figure 8.5: An Example of the Railroad Vernacular Architectural Style in the Railroad District

Photo: Adrianna Jordan.

The Railroad District Revitalization Plan “Opportunities and Constraints” section refers to “underused” street and railroad frontage adjacent to Santa Barbara between High and South Streets. This creates an unappealing landscape for pedestrians because buildings are set far back from the street, parking lots are located in the front or sides of shops, and there are numerous curb cuts. The recapturing of this "underused” street frontage through the creation of shared rear parking lots, elimination of curb cuts, and the development of new commercial pads with "build to” or “maximum” front setbacks could act as an energizing catalyst for expanding the district, creating a walkable area, and linking it to adjacent neighborhoods. Additionally, according to the city’s old Opportunities and Constraints map from 1998, there is a concern regarding noise and lighting sensitivity for the residential neighborhoods north of the Railroad District and any future developments, especially those oriented towards tourists, will need to address this issue in a sensitive manner.

\subsection{Potential for Economic Growth}

The potential for tourism and green industry-oriented economic growth in the Railroad District is well-documented in both the city’s award-winning Railroad District Historic Plan and the 
Railroad Museum Master Plan. In addition, as part of the research for this project, a detailed updated SWOT (Strengths, Weaknesses, Opportunities, and Constraints) analysis was conducted and the results were graphically rendered on an "Opportunities and Constraints” map (Figure 8.6). Prior to this effort, the last SWOT analysis had been conducted in 1998 as part of the Railroad District Historic Plan, and over the last 15 years extensive physical, economical, and political changes have occurred which necessitated the creation of a new SWOT analysis.

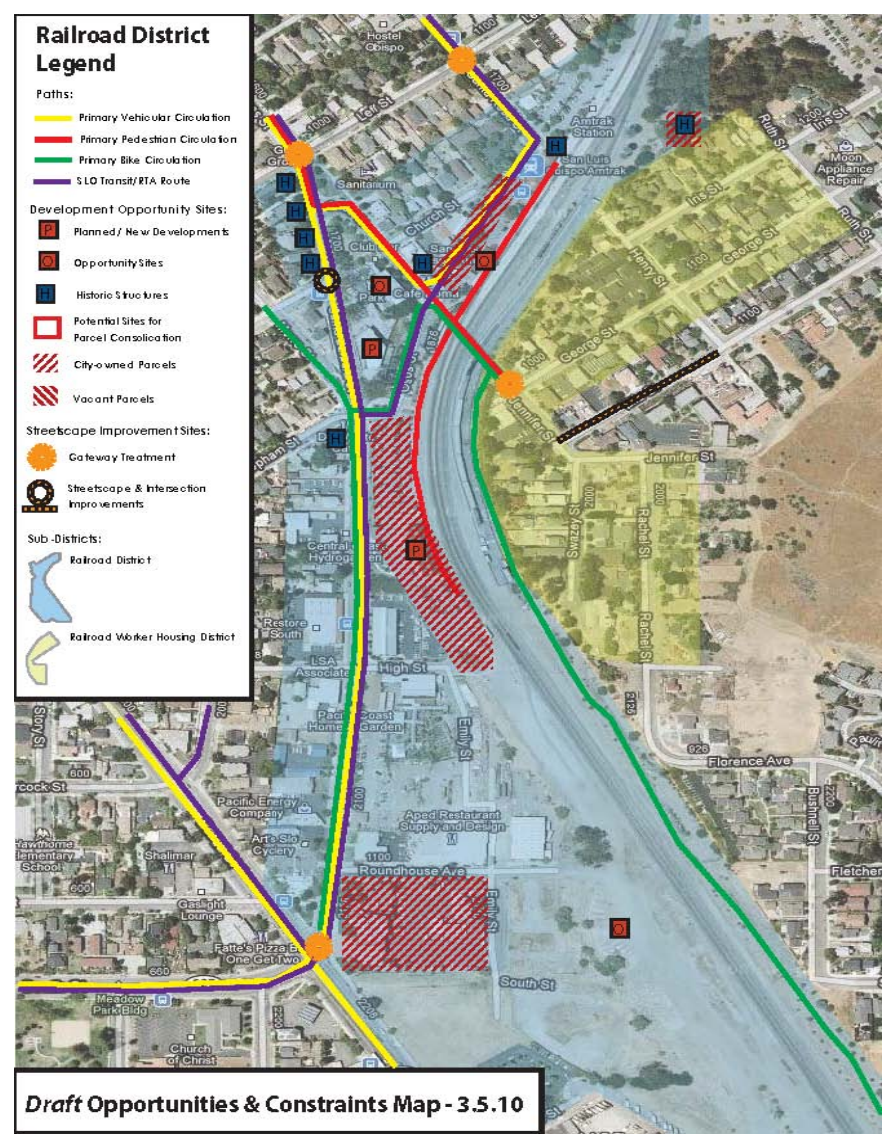

Figure 8.6: Opportunities and Constraints Map Graphic: Adrianna Jordan.

A summary of the Railroad District strengths, weaknesses, opportunities, and threats is as follows: 


\section{STRENGTHS}

- Well-preserved historic rail yard resources such as the art deco Amtrak Station (1942), Southern Pacific water tower (1940), Southern Pacific Transportation/REA Express Building (early 1900s), and the Railroad Museum/Southern Pacific freight warehouse building (1895).

- Well-preserved historic architecture within the Railroad District: Park Hotel (1906), Railroad Square Building (1912), Alano Club Building (1912), Call/Parkview Hotel ( 1886), Duff House (1901), Galewski House (1904), Tribune-Republic Building (1873), Del Monte Grocery (1922).

- Designated City of San Luis Obispo Parking District with ample public parking.

- Jennifer Street Bridge connects Railroad District to residential neighborhoods across the railroad tracks.

- Public art (Chinese Railroad Worker Memorial).

- Well-integrated with bicycle infrastructure and circulation (Railroad Safety Trail and specialized bicycle signal at intersection of Santa Barbara and Amtrak parking lot).

- District is well-landscaped.

- Multi-modal transit hub for the city (Amtrak trains and buses, Greyhound buses, SLO Transit buses, RTA buses).

- Central Coast Railroad Festival.

- Railroad Museum.

- New coffee shop (Sally Loo's) just opened up around the corner from the Amtrak Station.

- Well-established Café Roma restaurant across from the train station.

- Railroad District affords scenic views of the surrounding landscape.

- Good District branding and signage.

\section{WEAKNESSES}

- Vacant storefronts/lack of businesses to attract tourists (Park Hotel, Railroad Square).

- No decent all-ages lodging in the vicinity of the Amtrak Station. The existing Hostel caters primarily to young adults. 
- Alano Club is an incompatible use for the Railroad District.

- Visible evidence of soil contamination near the roundhouse foundations.

- Lack of historic signage in the District makes it difficult for visitors to decipher the area's historic resources.

- The area between the Amtrak Station and the Railroad Museum lacks sufficient street furniture and in particular - benches.

- There are maintenance issues with some existing streetscaping. For instance, the brick paving under the bench at the corner of Osos Street and Santa Barbara is being destroyed by tree roots.

- Some historic buildings in the District are becoming dilapidated.

- Osos Street between Santa Barbara and the railroad right-of-way lacks appropriate pedestrian-scaled street lighting.

\section{OPPORTUNITIES}

- Railroad District is easily accessible by car, foot, bicycle, train, or bus, and is located in the center of the City of San Luis Obispo.

- Amtrak station is serviced by both the Coast Starlight and the Pacific Surfliner passenger trains. Additionally, the Coast Daylight will resume passenger service between San Francisco and Los Angeles in 2011.

- Potential to extend Monterey Street tourist trolley loop from the Mission down to the Amtrak Station and the Railroad Museum.

- Restored Roundhouse could serve as a small business incubator for the city.

- District should capitalize on existing bicycle circulation by creating a "bike station" with bicycle rentals in the District.

\section{THREATS}

- Current economic conditions/lack of funding opportunities.

- Union Pacific Railroad does not appear to be interested in preserving its history in the San Luis Obispo area.

- Transient encampments along rail right-of-way.

- Railroad District is not very well-integrated with the historic downtown area. 


\subsection{Future Economic and Tourism Growth}

Ever since the adoption of the Railroad District Plan in 1998, significant positive momentum has been achieved in terms of plan implementation. For instance, current businesses in the Railroad District that enhance the revitalization efforts include restaurants, a coffee shop, a wine bar, and a bed \& breakfast. The upscale Sanitarium Bed \& Breakfast (Figure 8.7) was recently profiled in the Los Angeles Times, the New York Times, and Sunset Magazine. The Los Angeles times even made a special mention of the lodging's proximity to the train station: "We liked [owner Suzi Kyle's] style, from the whitewashed floorboards to the contemporary art on the walls to the wood-burning stoves and metal Moroccan soaking tubs in the guest rooms. And I love that next time we can arrive by train, stroll a block to the Sanitarium, then stroll six more blocks to the market” (Reynolds, 2007).

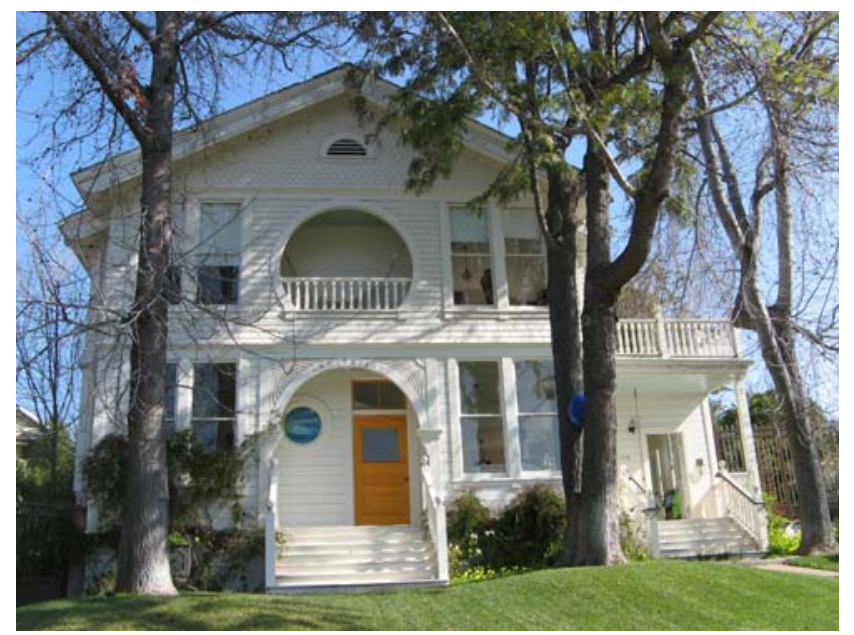

\section{Figure 8.7: The upscale Sanitarium Bed \& Breakfast Photo: Adrianna Jordan.}

One of the main business possibilities currently being proposed for the Railroad District is the reconstruction of the historic roundhouse. If Union Pacific could eventually be persuaded to sell 
the land (Figure 8.8) for a reasonable price, a reconstructed roundhouse could serve as a great space for innovative businesses in much the same way as the old Channel Commercial building houses small businesses today.

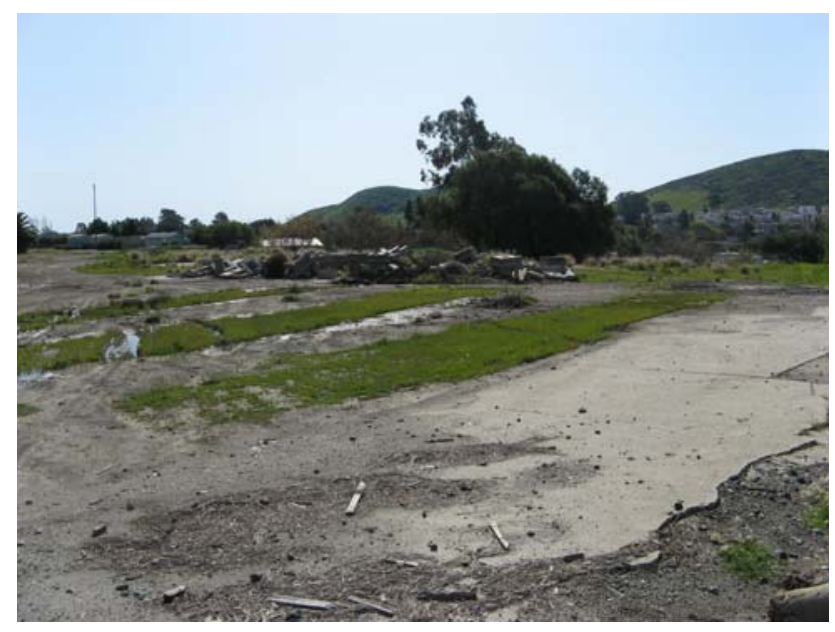

Figure 8.8: The Site of the Demolished Southern Pacific Steam Locomotive Roundhouse Photo: Adrianna Jordan.

Architectural components of the reconstructed roundhouse could also be open to the public for educational and railroad enthusiast tour groups, and portions of the structure could be used for the storage of Railroad Museum rolling stock. Additional land uses that could do well in the district include the adaptive re-use of old warehouses (Figure 8.9) into artists' live/work lofts, a model train store, the conversion of the Union Pacific security force office structure into a coffee/magazine shop, or a bicycle rentals shop (Figure 8.10). Also, although a successful Bed \& Breakfast already exists in the Railroad District, it is high-end and therefore unaffordable for the average family. Given that the Railroad Museum anticipates that middle-class families across California will take their children to the museum, there may be an untapped niche for a midmarket family-oriented Bed \& Breakfast in the Railroad District at the corner of Santa Barbara and Upham. 
In addition to commercial enterprises, the district will attract and keep tourists coming back if it mandates a healthy public art program. Possible means of including public art in the district could be to commission $3^{\text {rd }}, 4^{\text {th }}, 5^{\text {th }}$ year, and graduate Cal Poly students studying in artistic fields to design street furniture such as bicycle racks and information kiosks that double as public art that capitalizes on the theme of the railroad.

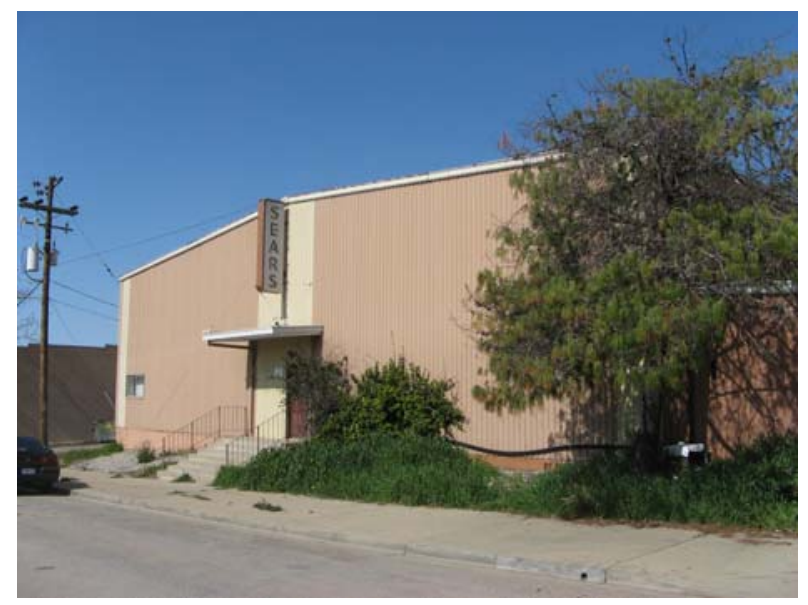

Figure 8.9: Old Sears Warehouse in the Railroad District Photo: Adrianna Jordan.

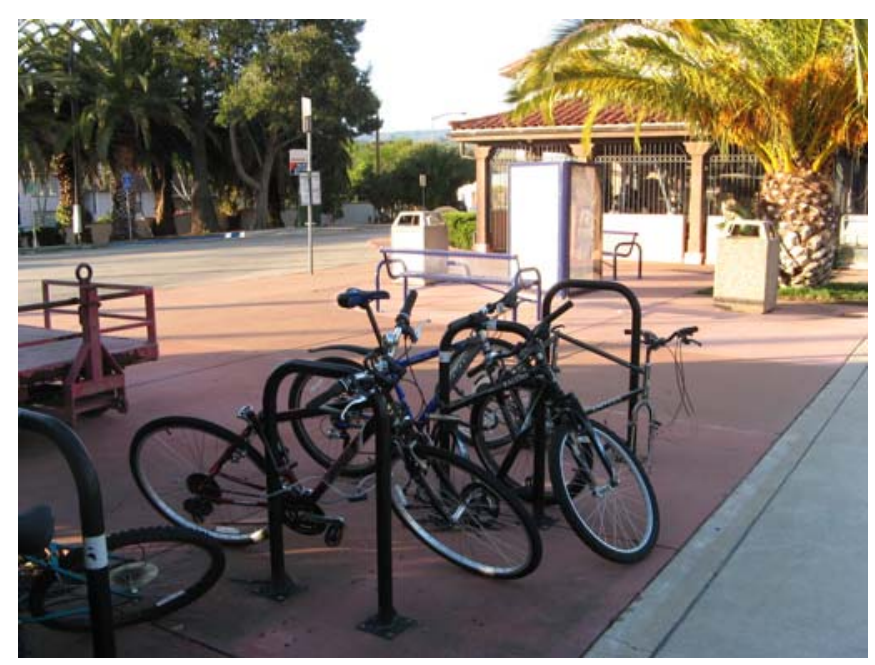

Figure 8.10: Existing Short-Term Bicycle Parking in the Railroad District Photo: Adrianna Jordan. 


\section{Connectivity}

One potential issue with the revitalization of the district concerns the surface parking. The district currently has enough shared parking to handle a potential influx of tourists, but if a portion of the parking is converted to other land uses it could decrease the visitors to the district without reliable alternative forms of travel put in place. The existing shared parking lot is one of only two shared surface parking lots in the city (the other is located downtown).

The use of alternative transportation facilities in the district would open up new possibilities such as the re-creation of the street car line between the Mission and the Railroad District. A streetcar line could increase tourism by providing a recorded narrative of historic points of interest along the route between the downtown and the district. Alternatively, the Monterey Street trolley route could be modified to run down to the Railroad District as part of its regular loop through the downtown area.

Another option to build the alternative transportation infrastructure in the area would be establishing a Bike Station. "Bike Stations" are facilities that provide long-term indoor bicycle storage, bathrooms, showers, bicycle maintenance facilities, and basic cycling supplies for sale (usually in the form of a vending machine). The first Bike Station was founded in Long Beach in 1996 and there are now Bike Stations located throughout California in Claremont, Covina, Long Beach, Palo Alto, and Santa Barbara. The location of the Bike Station would be very convenient due to its proximity to the city's Railroad Safety Trail which is a Class I bicycle facility that runs adjacent to the Union Pacific railroad tracks. Working in conjunction with the trail, the Americans with Disabilities Act (ADA) compliant Jennifer Street Bicycle and Pedestrian Bridge 
provides connectivity between downtown San Luis Obispo and the Terrace Hill residential neighborhoods located above the Union Pacific railroad tracks.

Additionally, Fun Ride has recently opened up in the Railroad District. Fun Ride is a car-sharing organization that allows members to pay a yearly fee to have access to cars that are strategically positioned around the City of San Luis Obipo. When a member checks out a car they pay for it on an hourly basis and the car insurance is included in the hourly fee.

Yet another use that might do well in the district, or might be a good attraction to have at Thursday's weekly downtown Farmers' Market is a "kiddie train” (Figures 8.11 and 8.12). A "kiddie train" at the market could act as a kind of advertisement for the district and the Railroad Museum, and perhaps it could even make special runs back and forth between the downtown and the museum.
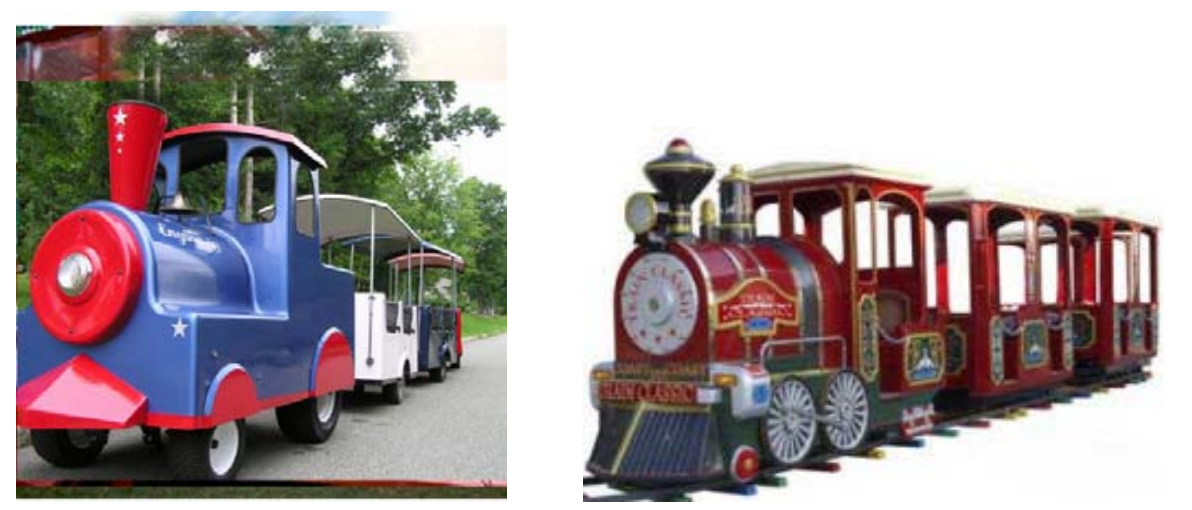

Figures 8.11 and 8.12: Two examples of "kiddie trains" Courtesy of Fun City Amusements (2011) and BMI Gaming (2011).

In the past, there was once a route created by the Chamber of Commerce called the Path of History Walking Tour. Although no longer maintained, it could be an option to connect the Page 111 
district to the former Path of History Walking Tour which is two miles long and takes approximately two hours to walk. It previously followed a green line through the city that used signage to highlight the Chamber’s program and the Historical Society’s Information. Despite the fact that the green line does not exist anywhere, the Chamber's Path of History Walking Tour still appears on the visitslo.com website and in the Chamber's Visitor Guide.

According to the City’s 1998 Opportunities and Constraints map, additional options for increasing connectivity within the Railroad District include possible pedestrian and cyclist connections over the Union Pacific Railroad at Penny Lane and at Lawrence Street, and a possible east-west street connection at Bishop Street. Finally, according to the same map, connectivity would be improved if street circulation was altered and traffic volumes more appropriately managed on Santa Barbara Street.

\section{Case Studies}

An important component of developing a plan for increasing growth and tourism in the railroad district was to review case studies of other notable railroad districts around the United States and to discover what types of development, infrastructure, and urban design worked best at increasing tourism. The results of the case study research are listed in Table 8.1. 
Table 8.1: Railroad District Case Studies

\begin{tabular}{|c|c|c|c|c|c|}
\hline Location & $\begin{array}{l}\text { Pop. } \\
\text { Size } \\
\text { (2000 } \\
\text { census) }\end{array}$ & District Name & $\begin{array}{l}\text { Date of } \\
\text { Revitalization }\end{array}$ & $\begin{array}{l}\text { Main } \\
\text { Attraction }\end{array}$ & Misc. Info \\
\hline $\begin{array}{l}\text { Ann Arbor, } \\
\text { MI }\end{array}$ & 114,024 & $\mathrm{n} / \mathrm{a}$ & 1970 & $\begin{array}{l}\text { Gandy Dancer } \\
\text { Restaurant (in } \\
\text { former depot) }\end{array}$ & $\begin{array}{l}\text { Original brick } \\
\text { streets }\end{array}$ \\
\hline $\begin{array}{l}\text { Ashland, } \\
\text { OR }\end{array}$ & 19,522 & $\begin{array}{l}\text { Historic Railroad } \\
\text { District }\end{array}$ & 1999 & $\begin{array}{l}\text { Railroad } \\
\text { Museum, Art } \\
\text { Galleries }\end{array}$ & Restaurants \\
\hline Chicago, IL & $\begin{array}{l}2.8 \\
\text { million }\end{array}$ & $\begin{array}{l}\text { Beverly/Morgan } \\
\text { Historic Railroad } \\
\text { District }\end{array}$ & 1995 & $\begin{array}{l}\text { Commuter Rail } \\
\text { Stations }\end{array}$ & $\mathrm{n} / \mathrm{a}$ \\
\hline Clovis, NM & 37,213 & $\begin{array}{l}\text { Historic Railroad } \\
\text { District }\end{array}$ & proposed & $\begin{array}{l}\text { Farmers' } \\
\text { Market, historic } \\
\text { locomotive }\end{array}$ & $\begin{array}{l}\text { Historic } \\
\text { residential } \\
\text { buildings }\end{array}$ \\
\hline $\begin{array}{l}\text { Flagstaff, } \\
\mathrm{AZ}\end{array}$ & 60,222 & $\begin{array}{l}\text { Historic } \\
\text { Downtown/Railroad } \\
\text { District }\end{array}$ & $\begin{array}{l}\text { Currently } \\
\text { undergoing } \\
\text { revitalization }\end{array}$ & $\begin{array}{l}\text { Historic } \\
\text { depot/visitor's } \\
\text { center }\end{array}$ & $\mathrm{n} / \mathrm{a}$ \\
\hline $\begin{array}{l}\text { Grapevine, } \\
\text { TX }\end{array}$ & 42,101 & $\begin{array}{l}\text { Cotton Belt Historic } \\
\text { Railroad District }\end{array}$ & 1992 & $\begin{array}{l}\text { Historic } \\
\text { depot/museum }\end{array}$ & $\begin{array}{l}\text { Blacksmith’s } \\
\text { shop, Farmers' } \\
\text { Market }\end{array}$ \\
\hline $\begin{array}{l}\text { Jamestown, } \\
\text { CA }\end{array}$ & 3,017 & $\begin{array}{l}\text { Railtown } 1897 \text { State } \\
\text { Historic Park }\end{array}$ & 1992 & $\begin{array}{l}\text { Preserved Sierra } \\
\text { Railway and } \\
\text { locomotive and } \\
\text { rolling stock }\end{array}$ & $\begin{array}{l}\text { locomotive } \\
\text { roundhouse, } \\
\text { machine shop, } \\
\text { and movie } \\
\text { paraphernalia }\end{array}$ \\
\hline $\begin{array}{l}\text { Pittsburgh, } \\
\text { PA }\end{array}$ & 334,563 & Station Square & 1976 & $\begin{array}{l}\text { Restaurants, } \\
\text { entertainment, } \\
\text { and hotel in } \\
\text { historic } \\
\text { buildings }\end{array}$ & $\begin{array}{l}\text { "waltzing } \\
\text { waters } \\
\text { fireworks" } \\
\text { fountain }\end{array}$ \\
\hline $\begin{array}{l}\text { Richmond, } \\
\text { IN }\end{array}$ & 39,124 & $\begin{array}{l}\text { Railroad Station } \\
\text { Historic District }\end{array}$ & 1987 & $\begin{array}{l}\text { Pennsylvania } \\
\text { Railroad Station }\end{array}$ & $\begin{array}{l}\text { Architecturally } \\
\text { significant } 19^{\text {th }} \\
\& 20^{\text {th }} \text { century }\end{array}$ \\
\hline
\end{tabular}

Page 113 


\begin{tabular}{|c|c|c|c|c|c|}
\hline & & & & & buildings \\
\hline $\begin{array}{l}\text { Sacramento } \\
\text {, CA }\end{array}$ & 407,018 & Old Sacramento & 1976 (museum) & $\begin{array}{l}\text { California State } \\
\text { Railroad } \\
\text { Museum }\end{array}$ & $\begin{array}{l}\text { Historic } \\
\text { locomotives }\end{array}$ \\
\hline $\begin{array}{l}\text { Santa Rosa, } \\
\text { CA }\end{array}$ & 161,496 & $\begin{array}{l}\text { Railroad Square } \\
\text { Historic District }\end{array}$ & 1979 & $\begin{array}{l}\text { Shopping, } \\
\text { restaurants, \& } \\
\text { entertainment }\end{array}$ & $\mathrm{n} / \mathrm{a}$ \\
\hline $\begin{array}{l}\text { Sheridan, } \\
\text { WY }\end{array}$ & 15,804 & $\begin{array}{l}\text { Historic Railroad } \\
\text { District }\end{array}$ & 2004 & Sheridan Inn & $\begin{array}{l}\text { Architecturally } \\
\text { significant } 19^{\text {th }} \\
\text { \& 20th } \\
\text { buildings }\end{array}$ \\
\hline $\begin{array}{l}\text { Springfield, } \\
\text { MA }\end{array}$ & 154,082 & $\begin{array}{l}\text { Downtown Railroad } \\
\text { District }\end{array}$ & 1983 & $\begin{array}{l}\text { Transportation/ } \\
\text { Architectural } \\
\text { significance }\end{array}$ & $\mathrm{n} / \mathrm{a}$ \\
\hline
\end{tabular}

Surprisingly, the success of the various districts appears to have very little to do with the population of the area, as the case study city size varies widely from 3,000 to three million people. Looking more closely at the towns that are similar in size to San Luis Obispo, a pattern emerges with respect to the scope of the revitalization that these towns pursued. In particular, most of the medium-sized towns such as Ashland, Clovis, Flagstaff, and Grapevine concentrated on a themed catalyst project such as a display of railroad artifacts and memorabilia. Some districts then expanded on this by encouraging tourist-serving commercial enterprises centered on the catalyst project such as art galleries and restaurants. Researching the case studies also unveiled excellent examples of the adaptive re-use of buildings constructed in the Railroad Vernacular style such as in Old Sacramento and Ashland, although in some historically wealthier areas east of the Mississippi the railroad buildings made use of the more distinguished heavy masonry style iconic to H.H. Richardson's architecture and therefore coined “Richardsonian”. 
The old depot building in Ann Arbor Michigan is one example of a Richardsonian railroad structure and now houses the popular Gandy Dancer restaurant.

\section{The Railroad History Tour}

As first mentioned in the beginning of this chapter, one of the primary strategies for encouraging more tourism in the Railroad District will be to create movement between the downtown and the district and, more particularly, between the County Historic Museum and the Railroad Museum. A major way of facilitating this movement is to design a tour route between the two destinations that highlights points of history along the way. Given that people of all ages and physical abilities will want to visit the museums and their respective districts, three versions of the route have been designed based on the various modes of transportation available. The proposed tour route is shown in Figure 8.13: 


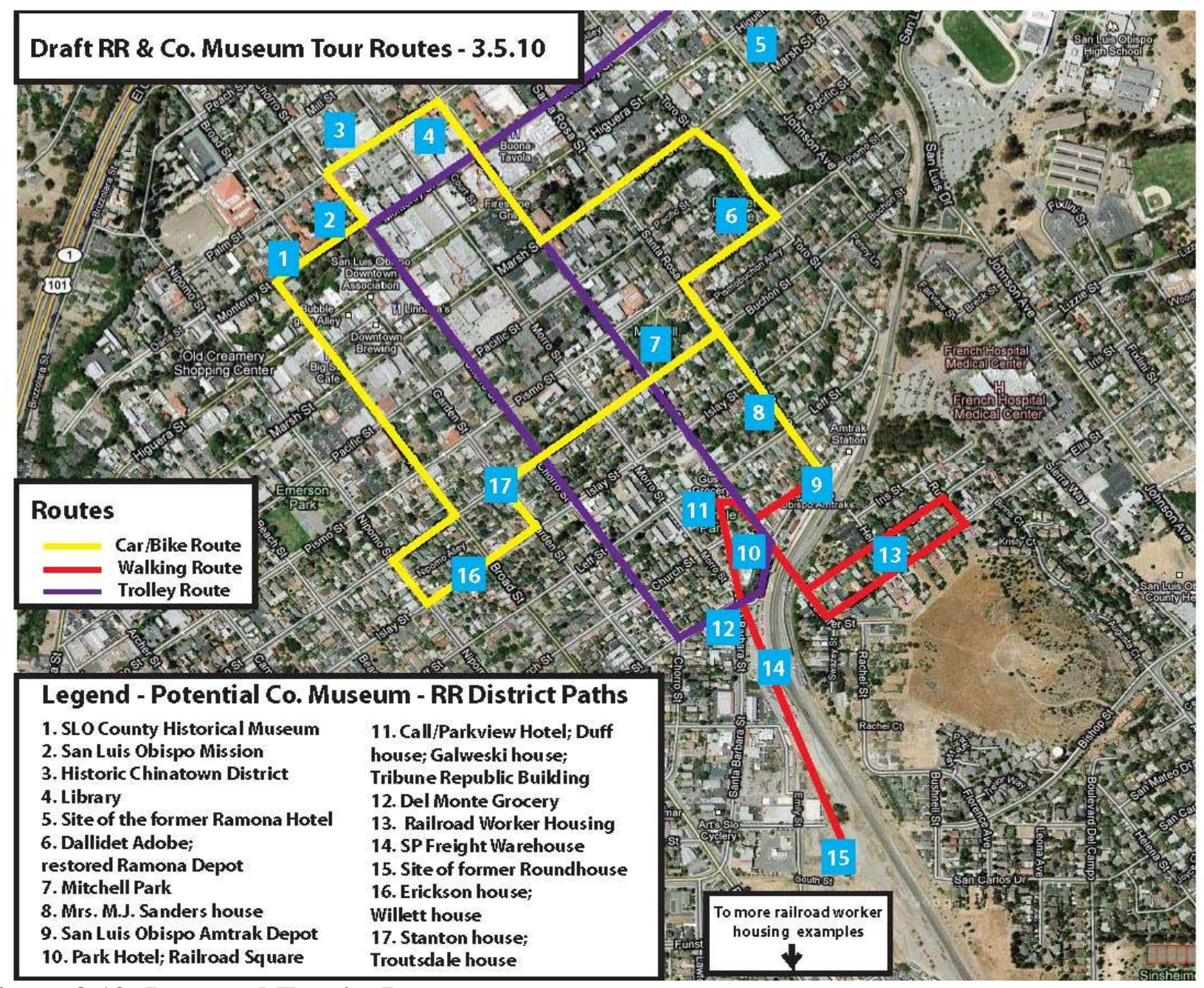

Figure 8.13: Proposed Tourist Routes Map: Adrianna Jordan. 


\section{Chapter 9: Conclusion}

The railroads have played an integral role in shaping both the fate and the physical landscape of the City of San Luis Obispo over the last 150 years. Although the heyday of rail as an economic driver in the city has come and gone, San Luis Obispo’s Railroad District, with the awardwinning Railroad District Plan for its place-making guide, is poised for continued revitalization. Public and commercial entities such as the Amtrak Station, the Railroad Museum, the Park Hotel building and its restaurants, and the Railroad Square Channel Commercial Building anchor the district and serve as pulse points of activity for locals and tourists alike. In addition, the Railroad District's excellent pedestrian and bicycle connectivity helps to link it with the rest of the city and channels people to it.

Given the present concern over greenhouse gas (GHG) emissions from motor vehicles, rising fuel costs, shortages of oil, and the centralized land-use patterns popular in New Urbanism and required by SB 375, it is possible that the railroad, or some other form of fixed rail public transportation might once again become a preferred mode of long-distance transport to the major metropolitan areas south and north of the city and beyond. If California does succeed in investing in a high speed train between San Francisco and Los Angeles, perhaps a connection into that corridor might be worked out. 
In the $21^{\text {st }}$ century there is a potential for both passenger and freight traffic to experience some shifts away from gasoline-powered modes of transport ${ }^{1}$. If and when that happens, the Railroad District in the City of San Luis Obispo may be in an excellent position to benefit from it. However, if it does not, given the growth of the city towards the airport in the south, the district's increasingly central location will create opportunities for both tourism-led, and innovative, and/or light-industrial economic growth. In the Railroad District, the charm and nostalgic connection to the history and architectural fabric of the past, as well as its strategic location for growing knowledge-based industries of the future, seems promising and worthy of investment.

\footnotetext{
${ }^{1}$ Passenger train service to the city of San Luis Obispo has increased in the past two decades from one through train daily in each direction between Los Angeles and Seattle (Coast Starlight) to include a regional train from Los Angeles to San Luis Obispo, and a train in each direction between San Diego and San Luis Obispo. "From 2000 to 2006 total ridership on both train services increased from 94,500 to 109,469 (15.8\%). During this time, ridership on the Coast Starlight fell 24,000 (43.6\%) from 55,000 to 31,000 due to track outages in Northern California, and track problems in Oregon and Washington. Ridership on the Pacific Surfliner increased 100\%, from 39,000 to over 78,000, due in part to the addition of a second train in 2004" (San Luis Obispo Council of Governments, 2010).
}

Page 118 


\section{References}

Atascadero News (1916). The Old Stage Road. Atascadero, CA: Atascadero News.

Best, G. M. (1964). Ships and Narrow Gauge Rails: The Story of the Pacific Coast Company. Berkeley, CA: Howell-North.

BMI Gaming (2011). Union Pacific Train Kiddie Amusement Ride. Retrieved from http://www.bmigaming.com/games-kiddie-rides-mall-trains.htm

California Department of Transportation (2008). California State Rail Plan 2007-08 to 2017-18 (2008). Sacramento: Author.

Cambria Chamber of Commerce (2010). A Brief History of Cambria. Retrieved from http://www.cambriachamber.org/history.php

City of San Luis Obispo (2001). Mid-Higuera Street Enhancement Plan. Retrieved from http://www.slocity.org/communitydevelopment/download/Mid-HigueraPlan.pdf

City of San Luis Obispo (2009). Planning Commission Staff Report Item \#1. Retrieved from http://www.slocity.org/communitydevelopment/plancom/Staff\%20Reports/0729091.pdf

City of San Luis Obispo (1998). Railroad District Plan. San Luis Obispo: Community Development Department. Retrieved from http://www.sanluisobispo.com/2011/07/20/1689026/changes-to-lanes-on-johnson-avenue.html Cornejo, A.M. (2011). Changes to lanes on Johnson Avenue in SLO are approved. San Luis Obispo Tribune.

County San Luis Obispo (2011). County of San Luis Obispo Airport Land Use Plan. San Luis Obispo County Planning and Building.

County of Santa Barbara Planning and Development Energy Division (2005). Brief Oil and Gas History of Santa Barbara County. Retrieved from http://www.countyofsb.org/energy/information/history.asp

Cox, W. and Vranich, J. (2008). The California High Speed Rail Proposal: A Due Diligence Report. Los Angeles: Reason Foundation.

Davis, E.A. (1914). Davis' Commercial Encyclopedia of the Pacific Southwest: California, Nevada, Utah and Arizona. Oakland: Ellis A. Davis.

Franks, J. (2004). San Luis Obispo: A History in Architecture. San Francisco: Arcadia Publishing. 
Fun City Amusements (2011). Trackless Train. Retrieved from http://www.funcityusa.net/mechanical_rides/Mechanical-Bigl---8.jpg

Haggard, K.\& Scholl E. (2008). A Brief Architectural History of San Luis Obispo County. San Luis Obispo, CA: Central Coast Publishing.

Heritage Shared (1998). Chinese San Luis Obispo. Retrieved from http://www.heritageshared.org/docs/chinese.html

Heritage Shared (2011). Living on the Land Tour. Retrieved from http://www.heritageshared.org/docs/livinglandtour1.html

Heritage Shared (2011). Random Image Photo Gallery. Retrieved from http://www.heritageshared.org/docs/gallery/ahlouisstore_front.html

Hess, C.N. (1934). What California Means to its Oldest Living Chinese: 1934 Interview with Ah Louis. Westways, 26 (3). Retrieved from:

http://historyinslocounty.org/Oldest\%20Living\%20Chinese.htm

The Historical Marker Database (2011). The Ramona Hotel Depot. Retrieved from http://www.hmdb.org/marker.asp?marker=38457

History in San Luis Obispo County (2001). The Sinsheimer Bros. Store. Retrieved from http://historyinslocounty.org/Sinsheimer\%20Brothers\%20Store.htm

Hubbard, J. (1989). Early History Sailed Around Cave Landing. Five Cities Times-PressRecorder.

Knowles, R. (1999). The Solar Envelope. University of Southern California. Retrieved from http://www-bcf.usc.edu/ rknowles/sol_env/sol_env.html\#anchor 474313

Krasner-Khait, B. (2003). The Impact of Refrigeration. History Magazine, February/March. Retrieved from http://www.history-magazine.com/refrig.html

Krieger, D. (1989). Looking Backward into the Middle Kingdom: San Luis Obispo County. Northridge, CA: Windsor Publications.

Krieger, D. (1998). War Comes to the Middle Kingdom, 1939-1942. Los Osos, CA: EZ Nature Books.

Landwehr, L. (2001). The Sinsheimer Bros. Store. History in San Luis Obispo County. Retrieved from http://historyinslocounty.org/Sinsheimer\%20Brothers\%20Store.htm

Miossi, H. (n.d.). Singular Crossing - the Historic Dimensions of Cuesta Pass. 
Monterey Peninsula Information (2011). Salinas Commuter Service and the Coast Daylight. Retrieved from http://www.montereypeninsula.info/delmonte/caltraindaylight.html

Nicholson, L. (1980). Rails Across the Ranchos. Fresno, CA: Valley Publishers.

Pacific Reporter 199 (1921). St. Paul: West Publishing

Parsons, G. L. (1995). Port San Luis: Trials and Tribulations 1855 to 1995. San Luis Obispo, CA: Author.

Reynolds, C. (2007). In the Market for Local Color. Los Angeles Times. Retrieved from http://www.latimes.com/travel/la-trw-slo27may27,0,2960446.story

Rice, W. (2006). San Luis Obispo’s Other Railroad. SLO County Journal.

San Luis Obispo Council of Governments (2010). Maximizing System Efficiency-

Transportation Demand Management/Transportation System Management (TDM/TSM). San Luis Obispo, CA: Author.

San Luis Obispo County History Center (n.d.). San Luis Obispo Street Railway System.

San Luis Obispo County History Center (2010). The Farmers’ Alliance and Industrial Union museum exhibit booklet.

San Luis Obispo Fire Department (1904). Souvenir of San Luis Obispo. San Luis Obispo, CA: Tigner.

San Luis Obispo Morning Tribune (1905). Obituary of Dr. G. B. Nichols. San Luis Obispo Tribune.

San Luis Obispo Railroad Museum (n.d.). Master Plan for the San Luis Obispo Railroad Museum. San Luis Obispo: Author.

South County Historical Society, Arroyo Grande, CA. Retrieved from:

http://www.southcountyhistory.org/

State of California Department of Fish and Game (2009). Pismo Creek/Edna Area Watershed Management Plan. Arroyo Grande, CA: Author.

Union Pacific (2010). Caltrans Briefing. Roseville, CA: Union Pacific.

US Gen Net (2011). Township and Range. Retrieved from

http://www.usgennet.org/usa/ok/county/muskogee/cemeteries/trro.html 
US National Archives (2011). Retrieved from

http://www.archives.gov/exhibits/powers_of_persuasion/use_it_up/images_html/ride_with_hitler .html

Westcott, K.E. and Johnson, C.H. (1998). The Pacific Coast Railway: Central California's Premier Narrow Gauge. Los Altos, CA: Benchmark Publications Ltd.

Wikipedia Amtrak. (n.d.) Retrieved May 13, 2011 from http://en.wikipedia.org/wiki/Amtrak

Wikipedia Coast Starlight. (n.d.) Retrieved May 13, 2011 from

http://en.wikipedia.org/wiki/Coast_Starlight 